ESCUELA TÉCNICA SUPERIOR DE INGENIERÍA AGRONÓMICA, ALIMENTARIA Y DE BIOSISTEMAS

DEPARTAMENTO DE PRODUCCIÓN AGRARIA

\title{
BIOLOGICAL AND OTHER SOIL PARAMETERS RESPONSE TO WINTER COVER CROPS IN A MEDITERRANEAN IRRIGATED SYSTEM
}

TESIS DOCTORAL

IRENE GARCÍA GONZÁLEZ

Ingeniera Agrónoma

Máster en Tecnología Agroambiental para una Agricultura Sostenible 

DEPARTAMENTO DE PRODUCCIÓN AGRARIA

ESCUELA TÉCNICA SUPERIOR DE INGENIERÍA AGRONÓMICA, ALIMENTARIA Y DE BIOSISTEMAS

UNIVERSIDAD POLITÉCNICA DE MADRID

BIOLOGICAL AND OTHER SOIL PARAMETERS RESPONSE TO WINTER COVER CROPS IN A MEDITERRANEAN IRRIGATED SYSTEM

Memoria presentada por:

Irene García González

Ingeniera Agrónoma

Para la obtención del grado de Doctor por la Universidad Politécnica de Madrid

Directores:

Dra. Chiquinquirá Hontoria Fernández; Doctora Ingeniera Agrónoma

Dr. Miguel Quemada Sáenz-Badillos; Doctor Ingeniero Agrónomo

Madrid, 2017 

Tribunal nombrado por el Magfco. y Excmo. Sr. Rector de la Universidad Politécnica de Madrid, el día de de

Presidente: Rafael Espejo Serrano

Vocal: Isabel Maria de Oliveira Brito

Vocal: Emilia Fernández Ondoño

Vocal: Petra Susan Kidd

Secretario: Marta Benito Capa

Suplente: Miguel Ángel Casermeiro Martínez

Suplente: Jason Kaye

Realizado el acto de defensa y lectura de la tesis el día de de en la E.T.S. de Ingeniería Agronómica, Alimentaria y de Biosistemas de la Universidad Politécnica de Madrid.

\section{CALIFICACIÓN:}

EL PRESIDENTE

LOS VOCALES 

A mis padres y familia 



\section{AGRADECIMIENTOS}

Muchas son las personas a las que querría dar las gracias por su participación en la realización de este trabajo. Han sido cuatro años de tesis durante los cuales he pasado por varias etapas y en cada una de ellas, muchos han sido los momentos o experiencias compartidos. Para todas esas personas querría dedicar unas líneas y así poder hacerlos parte de este trabajo.

En primer lugar a los directores de tesis, la Dra. Chiquinquirá Hontoria Fernández y el Dr. Miguel Quemada Sáenz-Badillos, cuya ayuda, dedicación y ánimos ha hecho posible la realización de este trabajo.

A todos los profesores de la unidad de Edafología, por su apoyo cuando surgía alguna duda o pregunta y por todos los consejos aportados. También por la compañía o breves momentos de desconexión durante las interminables horas delante del microscopio.

Al personal responsable de la finca "La Chimenea" del Instituto Madrileño de Investigación y Desarrollo Rural, Agrario y Alimentario de Aranjuez por la ayuda prestada en el ensayo de campo.

A María, Yuse y Rodrigo, por su compañía y ayuda durante los largos días en el campo, comidas y toma de muestras. A pesar del estrés en algunas semanas, siempre hubo muy buenos momentos que siempre recordaré.

A Clara Gómez Paccard y María Fernández Scola, por la elaboración de determinados análisis de campo y laboratorio.

A la gente de Wageningen University, en especial a Dra. Gerlinde de Deyn, Janna Barrel y Laura Martínez García, por su cálida acogida y apoyo durante mis meses en Holanda.

A la gente de Penn State University, en especial al Dr. Jason Kaye y Dra. Mary Ann Burns, por el tiempo invertido y todos los conocimientos transmitidos durante mi estancia en Estados Unidos.

Al Ministerio de Economía y Competitividad, por la beca FPI y la financiación de mi estancia en Holanda.

A todos mis amigos de Madrid y Talavera, por haber estado ahí, escuchándome, apoyándome y dando los ánimos necesarios cuando los he necesitado.

A mi familia, en especial a mis padres por ayudarme durante todos estos años y siempre haber estado ahí en cada momento. Por tener paciencia todos los días y apoyarme en todas mis decisiones. 

INDEX

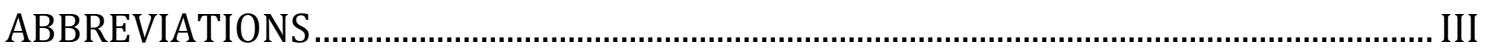

FIGURE INDEX

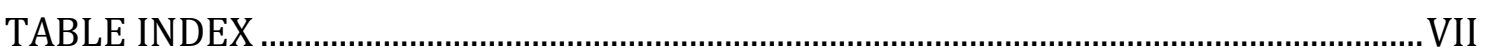

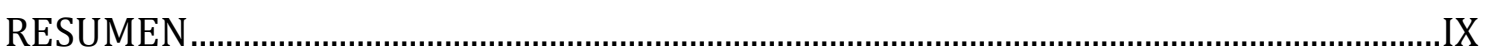

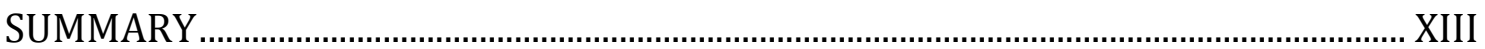

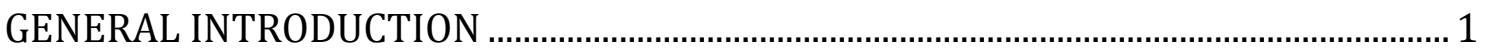

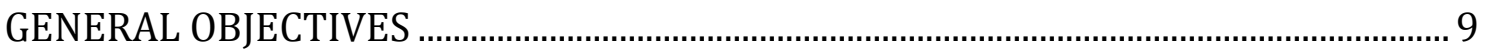

CHAPTER 1

Effect of cover crops on biochemical parameters related to soil quality in a long-term experiment .................................................................................................

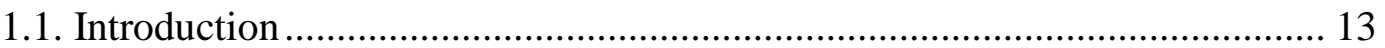

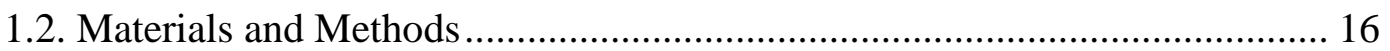

1.2.1. Study site and experimental design ................................................. 16

1.2.2. Field measurements, soil sampling and analysis ........................... 18

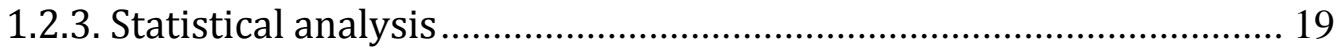

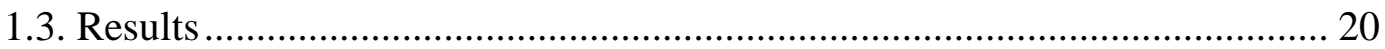

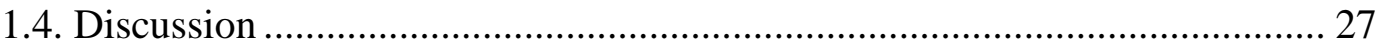

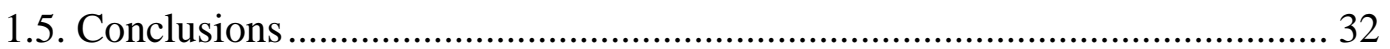

CHAPTER 2

Arbuscular mycorrhizal fungal activity responses to winter cover crops in a

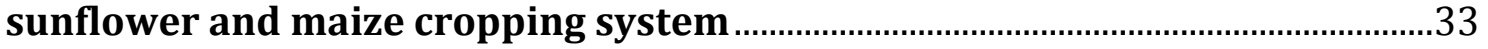

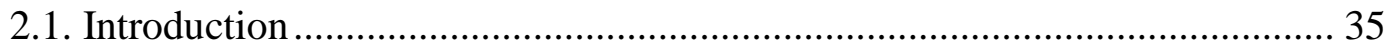

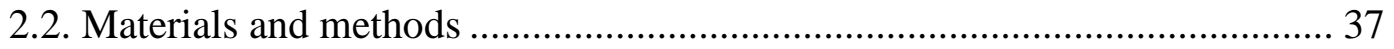

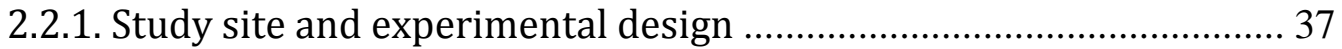

2.2.2. Field measurements, sampling and laboratory analysis .................. 39

2.2.3. Statistical analysis................................................................... 41

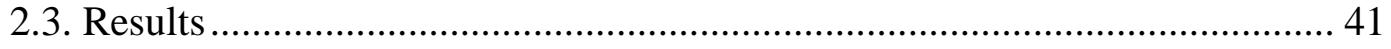

2.3.1. Soil water content evolution .......................................................... 41

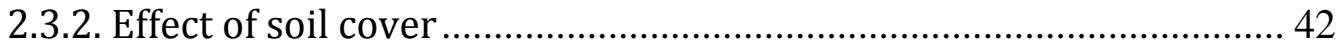

2.3.3. Relationships between the fungal and soil variables....................... 44

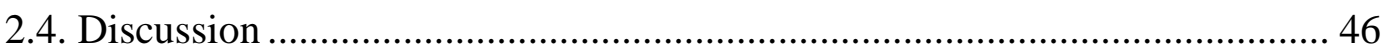


2.5. Conclusions

CHAPTER 3

Mycorrhizal activity, soil quality and plant parameters affected by winter cover crops

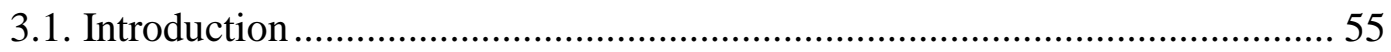

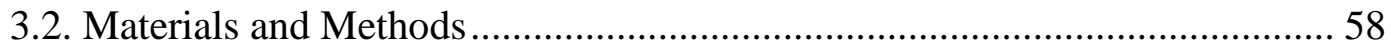

3.2.1. Study site and experimental design .............................................. 58

3.2.2. Analysis of maize roots and soil........................................................ 59

3.2.3. Maize plant measurements and analysis ...................................... 60

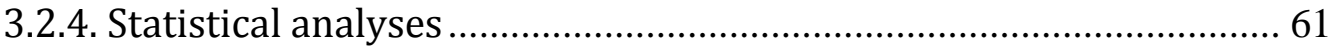

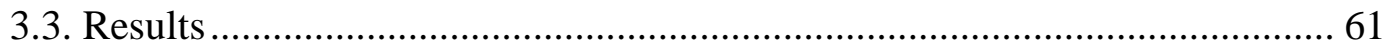

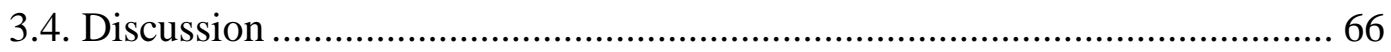

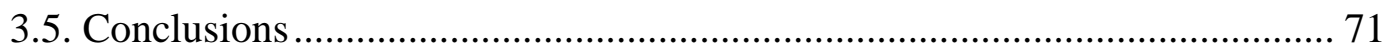

CHAPTER 4

Legacy effects of cover crop monocultures and mixtures on mycorrhizal

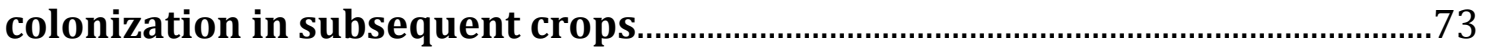

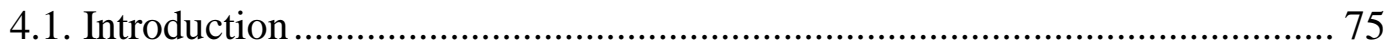

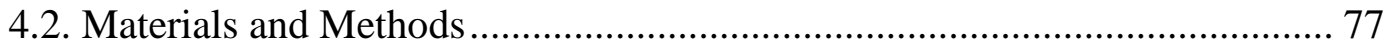

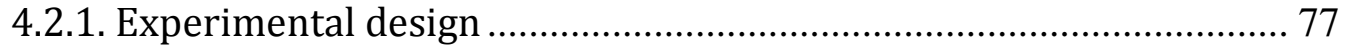

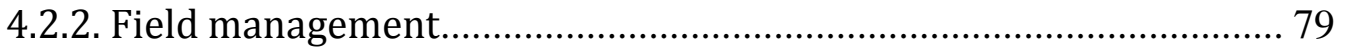

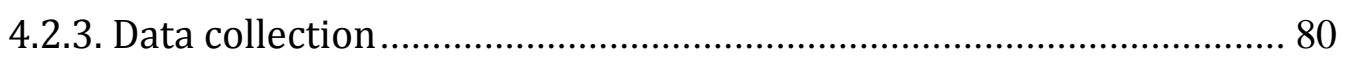

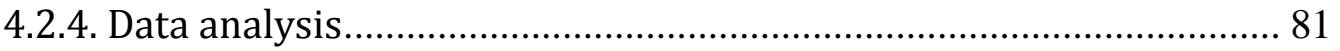

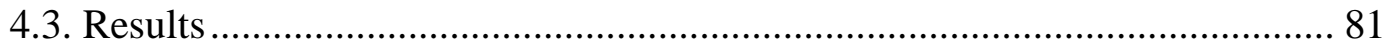

4.3.1. AMF colonization in endive roots in response to cover crop legacies

4.3.2. AMF colonization in oat roots in response to cover crop legacies.... 83

4.4. Discussion 84

4.4.1. Effects of cover crops on AMF colonization in succeeding main crops

4.4.2. Effects of main crop prior to cover crops on AMF colonization in

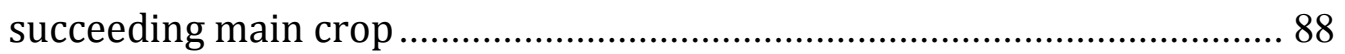

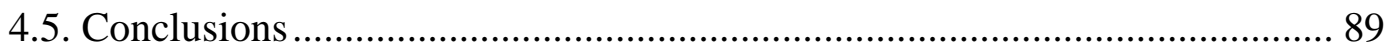

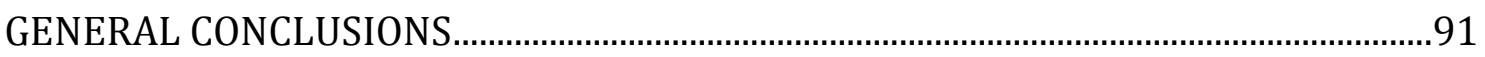

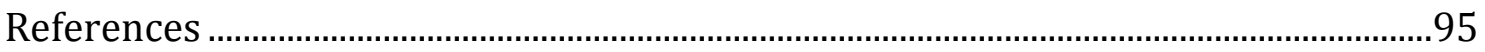




\section{ABBREVIATIONS}

AlP: alkaline phosphatase

AMF: arbuscular mycorrhizal fungi

ANOVA: analysis of variance

Aryl: arylsulphatase

C: carbon

CC: cover crop

$\mathrm{C}_{\text {mic }}$ : microbial biomass carbon

DAS: days after sowing

DD: degrees days

DH: dehydrogenase

EE-GRSP: easily extractable glomalin-related soil protein

ETc: crop evapotranspiration

FAO: food and agriculture organization of the United Nations

Fig.: figure

$\mathrm{G}+\mathrm{C}$ : ryegrass+clover

GRSP: total glomalin-related soil protein

HMA: hongos micorrícicos arbusculares

INT: 2- $\rho$-iodophenyl-3- $\rho$-nitrophenyl-5 phenyltetrazolium chloride

ITC: isothiocyanates

LSD: least significance difference

$\mathrm{N}$ : nitrogen

NAG: $\beta$-glucosaminidase

ns: statistically not significant

P: phosphorus

$\mathrm{R}+\mathrm{V}$ : radish+vetch

SE: standard error

SIR: substrate-induced respiration

SOM: soil organic matter

TOC: total organic carbon

Ure: urease

WSA: water stable aggregates

$\beta G$ : $\beta$-glucosidase 

FIGURE INDEX

\section{CHAPTER 1}

Fig. 1.1. Scheme of the field experiment design with four replicates of the three different treatments (left) and a photograph during the different winter treatments at La Chimenea, Aranjuez (right)

Fig. 1.2. Enzymatic activities of $\beta$-glucosidase (A), $\beta$-glucosaminidase (B), dehydrogenase (C) and urease (D) in 2010, 2012, 2014 and 2016 and alkaline phosphatase (E) and arylsulphatase (F) in 2014 and 2016. * and + indicate significant differences among treatments (LSD or Mann-Whitney, at P > 0.05) at 0$5 \mathrm{~cm}$ and 5-20 cm, respectively. Vertical bars represent standard errors.

Fig. 1.3. Microbial biomass carbon $\left(\mathrm{C}_{\mathrm{mic}}\right)$ and $\mathrm{pH}_{\mathrm{H} 2 \mathrm{O}}$ in 2010, 2012, 2014 and 2016. * and + indicate significant differences between treatments (LSD at P > 0.05) at 0-5 $\mathrm{cm}$ and 5-20 $\mathrm{cm}$, respectively.

Fig. 1.4. Easily extractable and total glomalin-related soil protein (EE-GRSP and GRSP) and total organic carbon (TOC) from 2008 to 2016. * and + indicate significant differences between treatments (LSD or Mann-Whitney, at P >0.05) at 0-5 $\mathrm{cm}$ and 5-20 $\mathrm{cm}$, respectively. Vertical bars represent standard errors. .23

Fig. 1.5. Soil respiration from 2010 to 2016. * indicates significant differences between treatments (LSD at $\mathrm{P}>0.05$ ). Vertical bars represent standard errors.....24

\section{CHAPTER 2}

Fig. 2.1. Soil volumetric water content at $10 \mathrm{~cm}$ depth (mean \pm standard error) for the three treatments. 41

Fig. 2.2. Means of root colonization, length of hyphae, AMF spores, easily extractable glomalin related soil protein (EE-GRSP), $\beta$ - glucosaminidase activity and water stable aggregates (WSA) at 54 and 69 DAS maize in 2013. Different lower case letters indicate significant difference among soil cover treatments according to Fisher's LSD at a 0.05 probability level. Different capital letters indicate significant difference between dates at a 0.05 probability level. Bars are the mean and small bars the standard error 43

Fig. 2.3. Linear relationship between root colonization and easily extractable glomalin-related soil protein (EE-GRSP) for all dates in both years in the barley, vetch and fallow treatments. 46

\section{CHAPTER 3}

Fig. 3.1. Arbuscular mycorrhizal fungi (AMF) parameters: mycorrhizal colonization, length of hyphae, arbuscular mycorrhizal spores and easily extractable glomalin-related soil protein (EE-GRSP) for the four sampling dates. 
Different letters for a given date indicate significant difference between treatments at $P<0.05$, according to Fisher's LSD test. Bars indicate SE

Fig. 3.2. Mean water stable aggregates (WSA) at 21, 36, 52 and 67 days after sowing maize. Bars with different letters for a given date indicate significant difference between treatments at $P<0.05$, according to Fisher's LSD test. Error bars indicate SE.

Fig. 3.3. Nutritional parameters in the soil $(\beta$-Glucosaminidase and alkaline phosphatase activities and available soil $\mathrm{P}$ content) and in maize plants (Shoot $\mathrm{P}$ and $\mathrm{N}$ concentration and Shoot $\mathrm{P} /$ Soil $\mathrm{P}, \mathrm{C} / \mathrm{N}$ and $\mathrm{N} / \mathrm{P}$ ratios). Different letters for a given date indicate significant differences between treatments at $P<0.05$, according to Fisher's LSD test. Bars indicate SE

\section{CHAPTER 4}

Fig. 4.1. Schematic of the field experimental design, divided into three phases......78

Fig. 4.2. Endive and oats crops in summer 2015 at Wageningen University field..79

Fig. 4.3. Legacy effects of cover crops: ryegrass, white clover, common vetch, radish, ryegrass+clover $(\mathrm{G}+\mathrm{C})$ and radish+vetch $(\mathrm{R}+\mathrm{V})(\mathrm{a})$ and of the preceding main crop endive or oat (b) on AMF colonization \% in endive roots. Different letters indicate significant differences among cover crops according to LSD test $(\alpha=$ 0.05 probability level). Vertical bars represent SE; (a) $N=10$, (b) $N=35$.

Fig. 4.4. Legacy effects of cover: ryegrass, white clover, common vetch, radish, ryegrass+clover $(\mathrm{G}+\mathrm{C})$ and radish+vetch $(\mathrm{R}+\mathrm{V})(\mathrm{a})$ and of the preceding main crop endive or oat (b) on AMF colonization \% in oat roots. Different letters indicate significant differences among cover crops according to LSD test $(\alpha=0.05$ probability level). Vertical bars represent SE; (a) $N=10$, (b) $N=35$. 
TABLE INDEX

\section{CHAPTER 1}

Table 1.1. Summary of the experiment history at La Chimenea field in Aranjuez (Madrid, Spain)

Table 1.2. Effect of cover crop treatments and years on enzymatic activities and microbial biomass carbon $\left(\mathrm{C}_{\mathrm{min}}\right)$ at both depths.

Table 1.3. Effect of cover crop treatments and years on easily extractable and total glomalin related soil protein (EE-GRSP and GRSP) and total organic carbon (TOC), at both depths.

Table 1.4. Correlation coefficients between biological properties and total organic carbon in $2010(0-5 \mathrm{~cm})$.

Table 1.5. Correlation coefficients between biological properties and total organic carbon in $2010(5-20 \mathrm{~cm})$.

Table 1.6. Correlation coefficients between biological properties and total organic carbon in $2012(0-5 \mathrm{~cm})$.

Table 1.7. Correlation coefficients between biological properties and total organic carbon in $2012(5-20 \mathrm{~cm})$.

Table 1.8. Correlation coefficients between biological properties and total organic carbon in $2016(0-5 \mathrm{~cm})$. .26

Table 1.9. Correlation coefficients between biological properties and total organic carbon in $2016(5-20 \mathrm{~cm})$.

\section{CHAPTER 2}

Table 2.1. Summary of the experiment history at La Chimenea field in Aranjuez (Madrid, Spain)

Table 2.2. Effect of the fallow, vetch and barley treatments on the variables directly related to arbuscular mycorrhizal fungi (AMF), the variables indirectly related to AMF (easily extractable glomalin-related soil protein, EE-GRSP, and $\beta$ glucosaminidase activity) and the percentage of water stable aggregates (WSA) at 95 DAS sunflower in 2012 (mean \pm standard error).

Table 2.3. Correlation coefficients and significance levels among the direct variables (root colonization, hyphae length, AMF spores), the indirect variables (easily extractable glomalin-related soil protein, EE-GRSP, and $\beta$-glucosaminidase activity) and the percentage of water stable aggregates (WSA) at 95 DAS sunflower in 2012. 
Table 2.4. Correlation coefficients and significance levels among the direct variables (root colonization, hyphae length, AMF spores), the indirect variables (easily extractable glomalin-related soil protein, EE-GRSP, and $\beta$-glucosaminidase activity) and the percentage of water stable aggregates (WSA) for the two sampling dates during maize cultivation in 2013. 45

\section{CHAPTER 3}

Table 3.1. Pearson correlation ( $r$ ) between the arbuscular mycorrhizal fungi (AMF) parameters: mycorrhizal colonization, hyphae length, AMF spores and easily extractable glomalin-related soil protein (EE-GRSP) and the percentage of water stable aggregates (WSA) at 21 days after sowing in the fallow, vetch and barley treatments.

Table 3.2. Pearson correlation ( $\mathrm{r}$ ) between the arbuscular mycorrhizal fungi (AMF) parameters: mycorrhizal colonization, hyphae length, arbuscular mycorrhizal fungi spores and easily extractable glomalin-related soil protein (EEGRSP) and the nutritional parameters at 21 days after sowing.

Table 3.3. Mean height of maize plants at 79, 87 and 95 days after sowing (DAS).

Table 3.4. Mean biomass and yield of maize plants and $\mathrm{N}$ content of maize grains at harvest.

\section{CHAPTER 4}

Table 4.1. Cover crop legacy effects on colonization percentage of arbuscular mycorrhizal fungi (AMF) hyphae, arbuscules and vesicles in endive roots (mean \pm standard error; $\mathrm{N}=10$ ).

Table 4.2. Cover crop effect on percentage colonization of arbuscular mycorrhizal fungi (AMF) hyphae, arbuscules and vesicles in oat roots (mean \pm standard error; $\mathrm{N}=10$ ). . .84 
RESUMEN

El reemplazo del tradicional barbecho de otoño-invierno por cultivos cubierta (CC) ha permitido la obtención de beneficios tanto a nivel de suelo como a nivel del cultivo principal. El estudio de la actividad microbiológica es un factor muy importante para llegar a comprender las interacciones suelo-planta y poder prever los cambios que se produzcan a corto plazo debido a las modificaciones en el manejo del sistema agrícola. La investigación se ha llevado a cabo en dos zonas de clima y suelos contrastados, una en España bajo condiciones mediterráneas y otra en Holanda bajo clima oceánico templado. La mayor parte del trabajo se ha realizado en un ensayo de campo de larga duración en Aranjuez (Madrid) con clima Mediterráneo semiárido. El ensayo se estableció en 2006 bajo condiciones de mínimo laboreo, en un suelo básico con signos de degradación producidos por el empleo continuado de laboreo convencional y monocultivo de maíz propio de la zona. Los tratamiento de invierno fueron: cebada (Hordeum vulgare L.), veza (Vicia villosa L. o V. sativa L.) y suelo desnudo como control. Durante los meses de verano, los cultivos principales fueron maíz (Zea mays L.) o girasol (Helianthus annuus L.) en regadío.

Para evaluar los cambios en la calidad biológica del suelo en respuesta al nuevo manejo se decidió, por un lado analizar la evolución a largo plazo de una serie de parámetros biológicos y por otro lado se realizó un estudio detallado de la actividad de los hongos micorrícicos arbusculares (HMA) en suelo y planta. En la primera parte se seleccionaron un conjunto de indicadores biológicos relacionados con la calidad del suelo para evaluar el efecto de los CC durante los diez años del ensayo de campo. Se determinaron actividades enzimáticas del suelo, $\mathrm{C}$ de la biomasa microbiana, las fracciones fácilmente extraíble y la total de la glomalina, respiración del suelo, así como el contenido en C orgánico. En la segunda parte, se estudió el efecto que producían los CC en la actividad de los HMA durante el siguiente cultivo en las variables directamente relacionadas con los HMA: colonización micorrícica, longitud del micelio externo y número de esporas. Además, también se analizaron otras dos variables que están relacionadas de una manera más indirecta con los HMA: la fracción fácilmente extraíble de la glomalina 
y la actividad de la $\beta$-glucosaminidasa. Durante el desarrollo del cultivo principal también se obtuvieron parámetros nutricionales en el suelo ( $\mathrm{P}$ disponible) y en planta (concentración de N, P y C), así como medidas de altura de la planta y rendimiento. Estos parámetros se midieron durante varias fechas para evaluar la duración de los efectos positivos de los CC a lo largo el crecimiento del cultivo principal.

El efecto en la colonización micorrícica de las raíces del cultivo principal es distinto dependiendo de si el CC es una leguminosa, una gramínea o una crucífera. Las mayoría de las especies de esta última familia no pueden formar asociaciones micorrícicas debido a sustancias antifúngicas presentes en las raíces. Así pues, la micorrización podrá variar dependiendo de las distintas especies de CC, condiciones climáticas, tipo de suelo y también de los propios cultivos en los que se esté analizando. Por ello, en un segundo ensayo de campo bajo condiciones propias de un clima oceánico templado, se estudió el legado de varios CC en la colonización micorrícica de las raíces de dos cultivos principales, avena (Avena sativa L.) y endivia (Cichorium endivia L.). Los tratamientos de invierno fueron: monocultivos de rábano (Raphanus sativus L.), veza ( $V$. sativa L.), trébol (Trifolium repens L.) y raigrás (Lolium perenne L.), mezclas de rábano+veza y raigrás+trébol y suelo desnudo.

En el ensayo de larga duración, los parámetros biológicos y el contenido en $\mathrm{C}$ orgánico total del suelo se vieron estimulados con la sustitución del barbecho por los CC. Las fracciones fácilmente extraíble y total de la glomalina fueron parámetros que respondieron a los dos años tras la introducción de los CC (en el año 2008). A continuación, en el año 2010 se observaron aumentos en las actividades de la $\beta$-glucosaminidasa y deshidrogenasa y en la respiración del suelo. El C de la biomasa microbiana no incrementó su contenido tras los CC hasta el 2012, cuando también lo hizo el C orgánico total. La mayoría de los parámetros fueron mayores en los primeros $5 \mathrm{~cm}$ del suelo en comparación con la segunda profundidad $(5-20 \mathrm{~cm})$. En general, se pudo ver cómo tras la implantación de los CC y el mínimo laboreo en el 2006, los indicadores bioquímicos de calidad del suelo fueron mejorando con el paso de los años bajo condiciones de clima 
Mediterráneo. La velocidad de respuesta de dichos parámetros fue muy diferente y el efecto llegó a ser más notable en la capa superficial.

La actividad micorrícica en el ensayo en clima Mediterráneo se vio afectada por el uso de CC. En las dos campañas de maíz (2012-2013 y 2013-2014), la cebada consiguió incrementar un 19\% la colonización micorrícica en el maíz, un 85\% la longitud de las hifas y un 64\% el número de esporas respecto al suelo desnudo. La veza en cambio no mostró mejoras en la mayoría de los parámetros micorrícicos. La fracción fácilmente extraíble de la glomalina obtuvo fuertes correlaciones con las variables directamente relacionadas con los HMA, lo que ha motivado su inclusión como un indicador más de la actividad micorrícica. Ambos CC contribuyeron a una mejora de la estabilidad de agregados debido en parte a los incrementos en la longitud de hifas y a la glomalina. El aumento de la actividad de los HMA encontrado en el tratamiento de la cebada condujo a incrementos en la concentración de P en la planta del maíz durante las primeras etapas de desarrollo. Fue el tratamiento de la veza el que mostró una mayor concentración en $\mathrm{N}$ en planta y actividades enzimáticas más elevadas de la $\beta$-glucosaminidasa y la fosfatasa. El estudio de las variables micorrícicas en varias fechas durante el crecimiento del maíz mostró que la colonización micorrícica fue el parámetro más afectado por la fecha de muestreo mientras que el resto de parámetros mantuvieron las diferencias entre tratamientos a lo largo del tiempo.

En el ensayo en clima templado, se obtuvieron similares resultados que en el ensayo en clima mediterráneo respecto a la colonización micorrícica entre gramíneas, leguminosas y suelo desnudo. Es decir, la gramínea estimuló la micorrización en los cultivos principales mientras que las leguminosas no se diferenciaron del suelo desnudo. En general, los tratamientos de raigrás y la mezcla raigrás+trébol tuvieron las colonizaciones más altas en comparación con el resto de tratamientos (un 60\% más alto en el caso de la avena y 188\% en la endivia comparado con el suelo desnudo). En la combinación de raigrás+trébol no se notó ninguna mejora en la micorrización comparado con el monocultivo de raigrás, a pesar de ser una mezcla gramínea-leguminosa. En las raíces de la avena se observó que el rábano produjo un efecto negativo en la colonización, disminuyendo un 51\% en comparación con el suelo desnudo. La incorporación de la leguminosa en la 
mezcla rábano+veza tampoco llegó a contrarrestar los efecto negativos del rábano (49\% menor que el suelo desnudo).

La sustitución del barbecho por los CC junto con una reducción en el laboreo comprende una buena práctica agrícola que puede mitigar, e incluso revertir, el efecto negativo derivado de la intensificación agrícola. Con este trabajo se demuestra que parte de los beneficios proporcionados por los CC en la calidad del suelo y crecimiento de la planta son debidos a la mejora de los parámetros biológicos, particularmente debido a la estimulación de los HMA. 


\section{SUMMARY}

Replacing the traditional fall-winter fallow with cover crop (CC) contributes to benefit both soil and the subsequent plant systems. The study of soil microbial activity is an important aspect to understand soil-plant interactions and to monitor the effect produced by changes of management practice in a short term. The research was carried out in two areas with different climates and soil characteristics. The first area was in Spain under Mediterranean conditions and the second in The Netherlands with a temperate oceanic climate. The main study for this work was carried out in a long-term field experiment in Aranjuez (Madrid) with a Mediterranean semiarid climate. The trial was established in 2006 with minimum tillage in an area with an alkaline soil and symptoms of soil degradation due to conventional tillage and maize monoculture, which are common practices in the area. The winter treatments were: barley (Hordeum vulgare L.), vetch (Vicia villosa L. or V. sativa L.) and fallow. During the summer, the main crops were maize (Zea mays L.) or sunflower (Helianthus annuus L.).

The biological soil quality indicators were evaluated on the one hand through a selection of soil biological parameters over the years, and on the other hand through a detailed study of the arbuscular mycorrhizal fungi (AMF) in the soil and plants. In the first stage, different biological indicators were selected to evaluate the CC effect during the long-term field experiment (10 years). Enzymatic activities, microbial biomass $\mathrm{C}$, both easily extractable and total glomalin fractions were evaluated in the soil along with soil respiration and also the total organic $\mathrm{C}$ content. In the second stage, the CC effect on the AMF activity in the subsequent main crop was studied in variables directly related to AMF: mycorrhizal colonization, length of hyphae and AMF spores. In addition, there were other two variables indirectly related to AMF: the easily extractable glomalin-related soil protein and the $\beta$-glucosaminidase activity. Nutritional parameters in the soil (available P) and plant (N, P and C concentrations) and maize height were obtained during the main crop, and yield at harvest. Those parameters were measured to monitor the positive CC effect in several sampling dates during the main crop growth. 
Cover crop species affect the mycorrhizal activity in different ways in the subsequent main crop. Legumes and grasses are common AMF hosts, but there are other species that cannot form mycorrhizal symbiosis, such as crucifers. Mycorrhizal colonization might vary depending on the different CC species used, climatic and soil conditions and also on the main subsequent crop. Therefore, the legacy of different CC on the AMF colonization in two subsequent crops was studied in a second field experiment under temperate oceanic climate. The winter treatments were: fallow, perennial ryegrass (Lolium perenne L.), white clover (Trifolium repens L.), vetch (V. sativa L.) and radish (Raphanus sativus L.), and the mixtures ryegrass+clover and radish+vetch. The mycorrhizal colonization was studied in the roots of two main crops: oat (Avena sativa L.) and endive (Cichorium endivia L.).

In the long-term experiment, the biological parameters and total organic $\mathrm{C}$ content were stimulated by the CC treatments. Both easily extractable and total glomalin fractions were the parameters earlier enhanced by CC (in 2008). Then, $\beta$ glucosaminidase and dehydrogenase activities and soil respiration showed improvements in 2010. Microbial biomass C did not show earlier increments than total organic C, both parameters were improved by both CC in 2012. Most of the parameters were higher in the first $5 \mathrm{~cm}$ depth compared with the second layer (5$20 \mathrm{~cm}$ ). Overall, after CC and minimum tillage establishment in 2006, the biological parameters related to soil quality increased through the long-term experiment under Mediterranean conditions. The response of these parameters was different and the effect was more notable in the upper layer.

The mycorrhizal activity was affected by the CC used in the Mediterranean long-term experiment. In the two maize campaigns (2012-2013 y 2013-2014), barley improved the mycorrhizal colonization in maize by $19 \%$, the length hyphae $85 \%$ and the AMF spores $64 \%$ compared with fallow. The vetch treatment, on the contrary, did not enhance most of the AMF parameters. The easily extractable glomalin fraction was correlated with the variables directly related to AMF, which contributed to include it as a variable directly related to AMF. Both CC contributed to improve the aggregate stability, due to increments in the length hyphae and glomalin content. The AMF stimulation by the barley CC enhanced shoot P 
concentration in the maize crop during the first growth stages. The vetch treatment had the highest shoot $\mathrm{N}$ concentration in maize plants and also $\beta$ glucosaminidase and phosphatase activities. The study of AMF parameters during various sampling dates showed that the mycorrhizal colonization was the parameter more sensitive to time. The differences on the other AMF parameters were constant over the time.

In the study under temperate oceanic climate, similar results were obtained compared with the Mediterranean experiment. Differences on mycorrhizal colonization between grasses, legumes and fallow were similar in both trials. That means that the grass stimulated the micorrhization in both main crops while the legumes showed no differences with fallow. Overall, ryegrass and ryegrass+clover treatments had the highest colonization compared with the other treatments (increments of $60 \%$ in oat and $188 \%$ in endive compared with fallow). The mixture ryegrass+clover showed no improvements in the mycorrhizal colonization compared with ryegrass monoculture, despite being a grass-legume combination. In the oat roots, the radish CC negatively affected the mycorrhizal colonization, decreasing by $51 \%$ compared with fallow. The mixture radish+vetch did not counterbalance the negative effect of radish ( $49 \%$ lower than fallow).

The replacement of fallow by CC together with tillage reduction constitutes good agricultural practice that can mitigate and even reverse negative effect derived from the intensification of cropping systems. This study demonstrates that part of the benefits provided by CC in soil quality and plant growth is through biological parameters enhancement and particularly via AMF stimulation. 



\section{GENERAL INTRODUCTION}

Agriculture is the largest interface between humans and environment. Since the notion of severe soil degradation in agricultural soil over the world (Lal et al., 1989), there has been a growing interest in preserving soil productivity, encouraging farmers to develop new agricultural conservation practices. Because of that, cropping systems that combine reduce or no-till practices and use of cover crops (CC) have attracted the interest of scientists and farmers (Frye et al., 1988).

Recognition of the green manure value of CC can be found from Cato (234149 B.C.) to Columela ( 4-70 A.D.) in the Mediterranean civilization (Semple, 1928). The use of legume CC was frequent in Chinese agriculture 2000 years ago (Pieters, 1927). It is hard to determine how widely CC were used through modern agriculture history, but the use of legumes to improve soil fertility was a common practice until synthetic fertilizers became easily available in the 20th century (Pieters and McKee, 1938). In the second half of the past century, CC were proposed as a way to control soil erosion and improve water quality (Kamprath et al., 1958; Pastor, 1988; Pieters, 1950) but the practice was not common in developed countries. Nowadays, cover cropping is considered one of the key practices in conservation agriculture that, together with reduced tillage, contributes to increasing the accumulation of soil organic matter (SOM), reducing soil erosion, improving water quality and diminishing the need of synthetic fertilizers (Thorup-Kristensen et al., 2003; Tonitto et al., 2006).

The role of CC in Mediterranean agriculture has not been sufficiently investigated, even if it has been identified as an important strategy for adaptation and mitigation under future climate scenarios (Kaye and Quemada, 2017). The use of CC to protect the soil between tree alleys is a well studied practice in olive groves and vineyards, being soil erosion control the main goal (Bienes et al., 2012; Sastre et al., 2016). Adoption of CC in rotations with arable crops of dry regions has been often limited because of low nutrient- and water-use efficiency (Unger and Vigil, 1998). In irrigated areas, replacing the traditional fall-winter fallow between 
cash summer crops is a more recent strategy that allows mitigating nitrate leaching and enhancing nutrient use efficiency (Gabriel et al., 2012; Gabriel and Quemada, 2011; Tosti et al., 2012). Even if irrigation allows to ensure CC establishment, under Mediterranean conditions it is necessary to bear in mind the water scarcity and the pre-emptive competition for water and nutrients between the winter CC and the summer crops for designing cover cropping systems (Alonso-Ayuso et al., 2014).

One of the most important decisions is selecting the adequate CC species, since the ability of the CC to extract soil water or to affect the nutrient cycles varies a lot (Clark, 2008). The species selection on nutrient cycling may have an effect not only through the direct nutrient uptake by the $\mathrm{CC}$, but also by the interaction of the crop with soil microorganisms (Kabir and Koide, 2000). A better knowledge of plant-soil-microbes interactions, and the role of soil microbes in plant nutrition and the maintenance of soil functions should permit a better understanding of our agricultural systems.

In general, CC improve SOM and aggregate stability (Liu et al., 2005), microbial activity (Hartwig and Ammon, 2002; Haynes and Francis, 1993; Quemada and Cabrera, 1995) and also reduce the nitrate leaching (Gabriel et al., 2012), weed establishment (Kruidhof et al., 2008) and pathogen diseases (Abawi and Widmer, 2000). However, different CC species will contribute to a great or lesser extent to generate soil changes. For example, legume crops are known to fix the $\mathrm{N}$ atmospheric because of the symbiotic association with Rhizobium and the faster $\mathrm{N}$ release during the mineralization process. There are numerous studies that also proposed grasses as CC, due to the wide range of adaptability to different climatic conditions, the higher biomass and roots systems compared with some legume species (Quemada et al., 1997; Ramirez-Garcia et al., 2014) and also to the rapid build of SOM (Snapp et al., 2005). Other important plant group used as CC is the crucifer, Brassicaceae species. Their great biomass accumulation above ground and root systems makes them relevant crops as nutrient resources, for the maintenance of soil microbial activity during winter or for weed and pest control (McGuire, 2003; Snapp et al., 2005). 
In the last years, societal and scientific concern about maintaining soil quality, plant health and soil resilience has led to increase the knowledge about soil microorganisms that form mutualistic association with plants (Van Der Heijden et al., 2006). The arbuscular mycorrhizal fungi (AMF) are an important biological alternative that benefits ecosystem sustainability and crop productivity, promoting plant growth and reducing inputs.

Arbuscular mycorrhizal fungi are one of the most common soil microorganisms. Their mycorrhizal symbiosis is widely spread in approximately $65 \%$ of land plant species (Wang and Qiu, 2006). The association consists in an exchange of resources between plant and fungus. These mycorrhizal interactions have coexisted with plants over 1000 million years ago, being an ancestral symbiosis that has played an important role in the evolution of land plants (Smith and Read, 2008). In contrast, the symbiosis by nitrogen-fixing Rhizobium bacteria evolved much later, approximately 60 million years ago (Lavin et al., 2005). Arbuscular mycorrhizal fungi are classified into the fungal phylum Glomeromycota, characterized by intercellular and intracellular colonization of the root cortex. They are obligated biotrophs, being necessary the host presence to complete their life cycle. The first contact between fungus and roots forms a structure called appressorium. From the entry point, fungal mycelium penetrates into the root and spreads through the cells, forming arbuscules that permit the exchange of nutrient (Cox and Tinker, 1976) and in some fungi also vesicles, that work as storage organs (Smith and Read, 2008). The extraradical mycelium that grows in the soil is in charge of absorbing nutrients and transporting them to the plant, and in turn, the plant transfers its photosynthetically fixed carbon to the fungus.

Mycorrhizal symbiosis plays an important role in the soil stabilization, biofertilization, bioprotection and bioregulation (Gianinazzi et al., 2010). On the one hand, AMF provide numerous advantages to the soil ecosystem, due to the presence of almost 50\% fungal mycelium in the soil (Rillig et al., 2002) and the glomalin accumulation, a glycoprotein produced by AMF (Rillig, 2004). Both of them, extraradical mycelium and glomalin secretion, contribute to soil aggregation 
and water retention, thereby improving soil structure and quality (Bedini et al., 2009; Caravaca et al., 2006). On the other hand, plants with AMF colonization enhance nutrient uptake, particularly P (Smith et al., 2009), improve their resistance against biotic (root pathogens) and abiotic (drought, salinity, heavy metals) stress (Gianinazzi et al., 2010; Smith and Read, 2008). The P application with fertilizers is necessary in most of the agricultural systems. The issue starts when after $\mathrm{P}$ application into the soil this becomes rapidly immobilized for plant uptake because of conversion to the organic forms, precipitation of mineral phosphates or adsorption of ions on soil surfaces (Holford, 1997). Soil microorganisms and enzymes are able to converse organic P into inorganic forms, therefore microbial activity is an important natural resource to keep active.

The AMF benefits, particularly notorious in the first crop stages, are correlated with improvements in P or N uptake (George et al., 1995; Ibijbijen et al., 1996; Kabir and Koide, 2002) soil structure (Miller and Jastrow, 2000) or interaction with other microorganisms (Artursson et al., 2006; Filion et al., 1999) which seems to have a relationship with an increase in the yield. However, there are studies that did not show direct correlations between AMF and final yields (Galvez et al., 2001; Sorensen et al., 2005; White and Weil, 2010). Therefore, the AMF contribution to increase the yield is unclear.

The mycorrhizal association is necessary to complete the fungus development; therefore long periods without plants or with plants that do not permit this symbiosis will reduce the AMF activity. Leaving the soil fallow during the fall-winter period may have a negative effect on the potential AMF inoculum that will influence the subsequent main crop (Kabir and Koide, 2000), particularly in semi-arid areas where fallows are scarcely covered by weeds and remain almost as bare soils. Keeping the soil cover with a CC provide a host to the mycorrhizal fungi and permit a fast colonization during the first stages of the next crop, taking advantage of the symbiosis benefits (Kabir and Koide, 2002; Lehman et al., 2012; White and Weil, 2010). However, it is unclear until what time or at what crop stage the AMF will affect the following crop by the CC legacy. This is relevant because when comparing between various land uses we are interested in showing up the 
differences. Sampling is recommended to be conducted in the early crop stages, since differences in root colonization may disappear over time (Gavito and Miller, 1998; Sorensen et al., 2005). In addition, AMF infection of the crop in early growth stages may be more important because it can be decisive in the success of the seedling establishment (Boswell et al., 1998). Therefore, the effect of replacing a fallow by a CC on AMF should be considered along with the sampling date.

Various CC species will provide different benefits to the AMF activity. Many authors have proposed the use of legume as CC, keeping the AMF inoculum active and besides providing an extra $\mathrm{N}$ supply to the next crop. The simultaneous $\mathrm{AM}$ colonization and nodulation of legumes lead to the idea of a tripartite symbiosis (El-Hassanin and Lynd, 1985). However, in some areas grasses work better maintaining higher levels of AMF propagules (Lehman et al., 2012). Other common CC are the Brassicaceae species that are non-AMF hosts. The presence of antifungal components in their systems called isothiocyanates (Fahey et al., 2001) and the lack of recognitions signal (Giovannetti and Sbrana, 1998) make them unsuitable for AMF colonization. Studies have shown that the residues of these species that remain in the field might be able to reduce the AMF colonization in the subsequent crop (Isobe et al., 2014; Koide and Peoples, 2012). On the other hand, there are studies that did not find a decrease of mycorrhizal colonization after Brassicaceae CC compared with fallow, suggesting that they did not always suppress the AMF activity in the subsequent crop (Njeru et al., 2014; White and Weil, 2010). An alternative to counterbalance the negative effect of these crops could be to mix them with AMF host plants that promote the colonization.

Arbuscular mycorrhizal fungi influence various factors in nutrient cycles (i.e. $\mathrm{P}, \mathrm{N})$ that in turn are affected by soil enzymes. These enzymes are proteins responsible for catalyzing the decomposition and nutrient mineralization processes, which allow microbes or plants to access energy and nutrients. In addition, they contribute to organic matter formation and stabilization of soil structure, playing an important role in agriculture (Dick, 1997). Their dependence of soil $\mathrm{pH}$, temperature variation and types of substrates and inhibitors (Tabatabai, 1994) makes the enzymatic activities sensitive parameters to changes of soil 
management (Bandick and Dick, 1999), such as different crop rotations, fertilization doses and soil amendments. The study of different enzymatic activities will provide indicators of soil fertility, soil health status and soil microbial processes (Nannipieri et al., 2012). Therefore, soil enzyme activities are considered sensitive indicators for soil degradation resulting from cultivation in semiarid areas (Caravaca et al., 2002).

Enzymes can be divided into different groups depending on their function in the soil, among which hydrolases and oxidoreductases are the predominant soil enzymatic activities (Alkorta et al., 2003; Garcia et al., 1997). Hydrolases are responsible for the catalytic hydrolysis of soil substances which have an important role in the $\mathrm{C}, \mathrm{N}, \mathrm{P}$ and $\mathrm{S}$ cycles ( $\beta$-glucosidase, urease, phosphatase, etc.). The enzymes involved in $C$ cycle like $\beta$-glucosidase or $\beta$-glucosaminidase release $C$ for energy which can be used by microorganisms (Ndiaye et al., 2000). Urease, phosphatase and arylsulphatase play an important role in the mineralization of $\mathrm{N}$, $\mathrm{P}$ and S compounds, respectively. They may indicate the soil potential to perform specific biochemical reactions and also contribute to soil fertility (Das and Varma, 2010). Oxidoreductase activities comprise the largest group that catalyzes reactions between two compounds, one of which is oxidized while reducing the other (dehydrogenase, catalase, peroxidase etc.). Soil contains extracellular and intracellular enzymes. An example of an intracellular enzyme is the dehydrogenase activity which is produced in all living microbial cells. It is used as an indicator of overall soil microbial activity due to the relationship with soil microbial respiration (García et al., 1993). The extracellular enzymes might be excreted from living cells, being associated with activity microbial cells for a short period of time, or they can be stabilized and accumulate in the soil (Tabatabai, 1994).

Among the benefits of cover cropping on soil microbial activity are the increase of enzyme activities and also the improvement of parameters such as the microbial biomass carbon $\left(\mathrm{C}_{\mathrm{mic}}\right)$ and the soil respiration (Acosta-Martínez et al., 2011; Marinari et al., 2006; Sainju et al., 2008; Tejada et al., 2008). The microbial biomass is the living component of SOM and participates in nutrient transformations and storage (Rice et al., 1996). The $\mathrm{C}_{\text {mic }}$ comprises 1-5\% of the 
total organic carbon (TOC) (Sparling, 1992). In a similar way, the soil respiration measured as $\mathrm{CO}_{2}$ flux directly to the field surface permits the control of small changes produced by organic matter addition and microbial respiration. In general, the selection of biological parameters must be sensitive enough to detect the differences on a temporal scale and between different field treatments. They respond more rapidly to changes than physical or chemical soil properties (Ekenler and Tabatabai, 2003). Therefore, the study of parameters related to soil quality during the recuperation of a degraded agricultural soil should give an earlier idea of how the soil ecosystems is been affecting by the new changes. 



\section{GENERAL OBJECTIVES}

The general objective of this work was to study the effect of replacing fallow with different winter CC on a selected group of soil and plant parameters related to soil quality and plant growth. To achieve this goal, specific objectives were to evaluate the effect of a variety of CC species on:

i) biochemical parameters throughout a long-term experiment (10 years),

ii) AMF activity in the subsequent sunflower and maize crops by studying direct and indirect variables related with AMF and its dependence over time,

iii) soil and plant parameters and its relationship with AMF during different maize development stages, and

iv) mycorrhizal colonization in oat and endive roots in a temperate climate.

The study was carried out in two different trials, the first one with maize or sunflower as main crops under Mediterranean climate and the second with endive and oat under temperate oceanic climate. 

Chapter 1

Effect of cover crops on biochemical parameters related to soil quality in a longterm experiment 



\subsection{INTRODUCTION}

Conventional tillage is a common practice in agricultural systems of central Spain that has carried out soil degradation with organic matter losses, superficial soil crusting, nutrient leaching, etc. The shift to more sustainable agricultural practices such as minimum tillage or including winter cover crops (CC) in the last decades is improving soil structure and protecting the soil from wind and water erosion. Cover cropping also enhances soil organic matter (SOM) content, aggregation stability and microbial activity (Ding et al., 2006; Kabir and Koide, 2000; Mendes et al., 1999; Muñoz et al., 2007; Veenstra et al., 2007). However, in semiarid climate areas with limitations of water availability and nutrients uptake, the benefits of CC establishment do not seem to be clear, showing in some cases reductions in the main crop yield (Lascano et al., 2015; Salmerón et al., 2010).

Biological parameters have been proposed as sensitive indicators of changes in soil management due to their rapid response and their relationships with soil quality (Elliott, 1994; Gil-Sotres et al., 2005; Lagomarsino et al., 2009). Among these characteristics, soil enzymatic activities are proposed as early indicators to new crop incorporations in agricultural systems (Acosta-Martínez et al., 2011; Acosta-Martinez et al., 2007; Bandick and Dick, 1999). Enzyme activities have close relationships with soil microorganisms, plants, environmental effects and ecological interactions, and because of their involvements in nutrients cycles they have been suggested as soil fertility indicators (Dick and Tabatabai, 1993). Monitoring enzyme activities in long-term experiments is a way to evaluate the soil health (Frankenberger and Dick, 1983).

$\beta$-Glucosidase enzyme is related to the transformation and recycling of SOM, as it is involved with the $\mathrm{C}$ cycle (Tabatabai, 1994). In $\mathrm{N}$ cycling, the urease enzyme catalyzes the urea hydrolysis to $\mathrm{CO}_{2}$ and $\mathrm{NH}_{3}$. $\beta$-Glucosaminidase is considered to be important in both $\mathrm{C}$ and $\mathrm{N}$ cycles and together with the arylsulfatase are indicators of fungal biomass. $\beta$-Glucosaminidase is in charge of chitin degradation, the main structural compound from fungal cell walls (Miller et al., 1998) and arylsulfatase is involved in the sulfur cycle due to the presence of the ester sulfate of fungi (Bandick and Dick, 1999). Phosphatases have been widely studied due to 
their role in the soil organic P mineralization and plant nutrition (Nannipieri et al., 2012). They are dependent on soil $\mathrm{pH}$, therefore in soils with high $\mathrm{pH}$ the alkaline phosphatase activity will predominate. With all of this information, the study of enzyme activities would be a way to determine the soil capacity to react to external change, impact, or degradation such as that induced by agricultural practices.

Arbuscular mycorrhizal fungi (AMF) are symbiotic microorganisms widely spread around the world that colonized soil and plant roots. They play an important role in soil structure because of their hyphae network and a substance called glomalin, located in the AMF hyphae and spores (Driver et al., 2005). This glycoprotein is accumulated in the soil particles and might represent $5 \%$ of soil C and N (Lovelock et al., 2004a; Rillig et al., 2003), resulting in a nutrient source for plants and the other organisms in the soil. Glomalin also acts as a cement agent and its presence in roots and aggregate surfaces contribute to a direct relationship with soil aggregate stability (Wright and Upadhyaya, 1998).

Total organic carbon (TOC) content is a soil quality indicator that is affected by the changes in the crop management such as intensive tillage and the addition of crop residues to the soil (Chavarría et al., 2016; Muñoz et al., 2007; Nivelle et al., 2016; Veenstra et al., 2007; Villamil et al., 2006). Benefits in soil structure are related to its accumulation in the soil and an increase in the formation and stabilization of soil microaggregates and macroaggregates (Beare et al., 1994). However, sometimes TOC might not be considered a very sensitive indicator in short term agricultural systems (Alvarez and Alvarez, 2000) because of a slight or non-existent increase in its content (Lagomarsino et al., 2009; Mendes et al., 1999; Olson et al., 2010). For this reason, the evaluation of a labile fraction of the organic matter, the microbial biomass carbon $\left(\mathrm{C}_{\mathrm{mic}}\right)$ seems to provide earlier changes in SOM contents rather than TOC.

The microbial biomass carbon $\left(\mathrm{C}_{\mathrm{mic}}\right)$ is a living fraction of organic matter, responsible for its decomposition and nutrient turnover. Therefore, it might be a useful and more sensitive measurement of any change in organic matter status. A field experiment by Acosta-Martínez et al. (2011) showed higher $C_{\text {mic }}$ in CC treatments after 3 years. However, there are other studies such as Mbuthia et al. 
(2015) which did not show any increment with CC use in a long-term experiment or Melero et al. (2009) in which did not observe an improvement of the $\mathrm{C}_{\text {mic }}$ three years after changing to conservation tillage. It seems that the soil microbial biomass is highly variable due to sensitivity to seasonal environmental factors, management practices, soil and crop types (Carter et al., 1999; Gonzalez-Quiñones et al., 2011).

Both soil microorganisms and plant roots contribute to the overall $\mathrm{C}$ production in fields (García-Izquierdo, 2003), therefore the $\mathrm{CO}_{2}$ release directly in the field might be considered as a measurement of the gross soil metabolic activity. Soil respiration measurements over the soil surface show much higher variability than those in the laboratory. This is because they reflect the spatial variation of chemical and physical soil properties and changing environmental conditions (Steenwerth et al., 2010).

Monitoring the variations of biological and chemical soil properties in field experiments with $\mathrm{CC}$ and minimum tillage will permit the evaluation of crop systems sustainability in the soil and in the crop production. However, despite the importance of these types of agricultural practices, few long term experiments have been carried out in Mediterranean areas where all of these characteristics are integrated. Our work was conducted in a long-term field experiment established in Central Spain under a characteristic irrigated area with symptoms of soil degradation such as low aggregate stability, loss of nutrients and tendency to surface crust. With the purpose of evaluating soil quality, we studied microbial activity by selecting a number of soil enzymes and other biological properties in a CC system with irrigated maize in summer. Specific objectives were to assess: i) the effect of different CC on soil enzymatic activities and other biological parameters and their evolution over the years; ii) the influence of $\mathrm{CC}$ on soil $\mathrm{C}$ content and its evolution over the years and iii) relationships among the selected biological parameters. 


\subsection{MATERIALS AND METHODS}

\subsubsection{Study site and experimental design}

The study was conducted in a field experiment stablished at La Chimenea Field Station in $2006\left(40^{\circ} 03^{\prime} \mathrm{N}, 03^{\circ} 31^{\prime} \mathrm{W}, 550 \mathrm{~m}\right.$ a.s.l.). It is located in the central Tajo river basin near Aranjuez (Madrid, Spain) with a Mediterranean semiarid climate (Papadakis, 1966). The soil is clay loam (Typic Calcixerept; Soil Survey Staff (2014)). The properties of the top soil $(0-20 \mathrm{~cm})$ are $\mathrm{pH}_{\text {water }}$ (1:2.5), 8.1; organic matter, $18 \mathrm{~g} \mathrm{~kg}^{-1}$; calcium carbonate, $198 \mathrm{~g} \mathrm{~kg}^{-1}$; sand (2000-50 mm), silt (50-2 mm) and clay (<2 mm) content, 260, 490 and $250 \mathrm{~g} \mathrm{~kg}^{-1}$, respectively. Before establishment of this study, the area had a maize monoculture system and was managed with conventional tillage practices.

In October 2006, the field site was divided in twelve plots $\left(12 \times 12 \mathrm{~m}^{2}\right)$. It was randomly distributed in four replications of three treatments: barley (Hordeum vulgare L., cv. Vanessa) and vetch (Vicia villosa L., cv. Vereda from 2006 to 2013 and V. sativa L., cv. Aitana from 2014 to 2015) as CC during the fall-winter period, with fallow as the control (Fig. 1.1). The CC were broadcasted by hand over the stubble of the previous crop and covered with a shallow cultivator ( $\sim 5 \mathrm{~cm}$ depth) that passed over all of the plots in October. All treatments were treated with one application of glyphosate 2\% (N-phosphonomethyl glycine) in March to terminate the CC. The main crop, maize (Zea mays L., G-98 Pioneer) or sunflower (Helianthus annuus L., var. Sanbro) was sown in early spring over the chopped CC residue by direct sowing and harvested in early autumn. Water was uniformly applied using a sprinkler irrigation system $\left(12 \times 12 \mathrm{~m}, 9.5 \mathrm{~mm} \mathrm{~h}^{-1}\right)$ according to crop evapotranspiration (ETc) requirements calculated by the FAO method (Allen et al., 1998). 

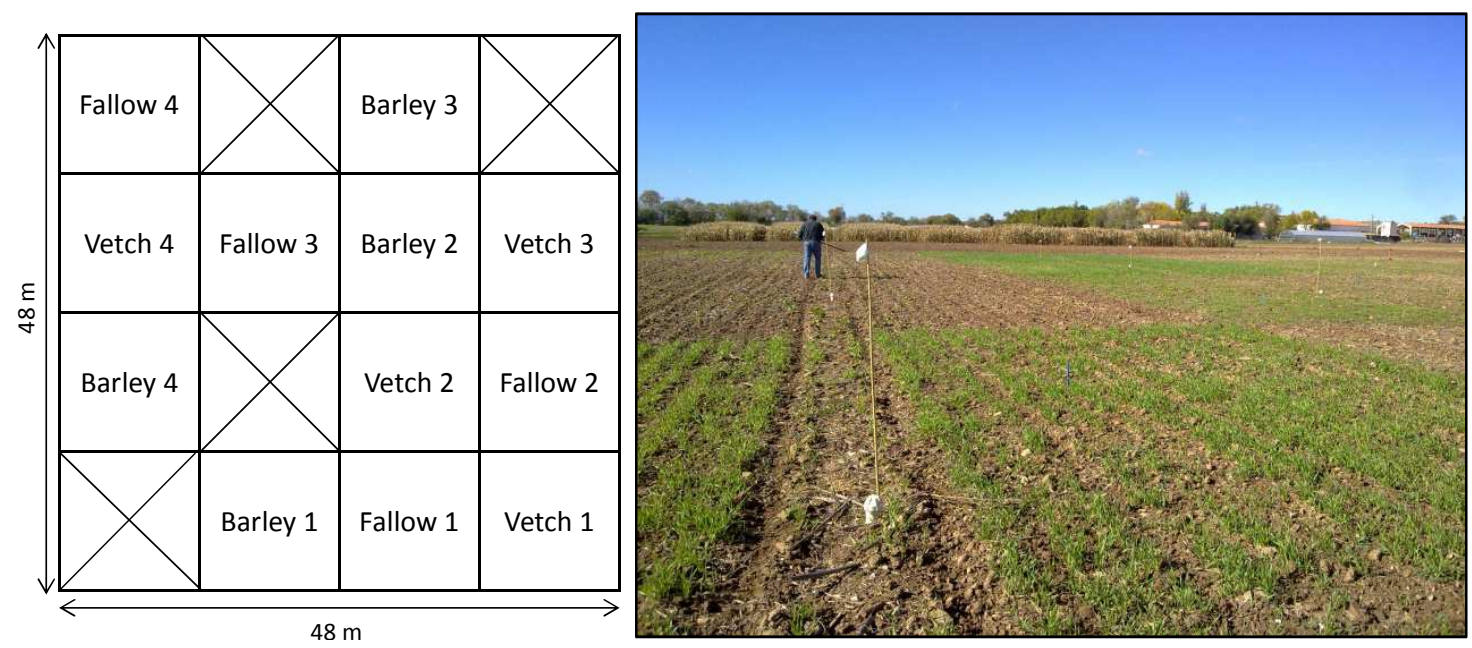

Fig. 1.1. Scheme of the field experiment design with four replicates of the three different treatments (left) and a photograph during the different winter treatments at La Chimenea, Aranjuez (right).

Throughout the long-term experiment, there were three different phases where the doses of fertilizers were modified. In the first period, from 2006 until 2010 all plots received the same amount of synthetic fertilizer: ammonium nitrate (210 kg N ha-1) split into two applications when maize had 4 and 8 leaves, and before sowing the main crop $120 \mathrm{~kg} \mathrm{P} \mathrm{ha}^{-1}$ as triple superphosphate and $120 \mathrm{~kg} \mathrm{~K}$ $\mathrm{ha}^{-1}$ as potassium sulfate. Fertilization was suspended in the second period, from 2011 to 2012. In the third stage, from 2013 on, the fertilization was adjusted based on each winter treatment requirements. Cover crop residues remained in the field, whereas the maize and sunflower residues were removed from the experiment, leaving the same amount $\left(\approx 1000 \mathrm{~kg} \mathrm{ha}^{-1}\right)$ in all of the plots. A summary of the management during the long-term experiment is shown in Table 1.1. 
Table 1.1. Summary of the experiment history at La Chimenea field in Aranjuez (Madrid, Spain).

\begin{tabular}{ccccccc}
\hline \multirow{2}{*}{ Crop } & \multirow{2}{*}{ Sowing } & $\begin{array}{c}\text { Harvest or } \\
\text { CC killing }\end{array}$ & Fallow & Vetch & Barley & Fertilization \\
(kg N-P $\left.\mathrm{O}_{5}-\mathrm{K}_{2} \mathrm{O} \mathrm{ha}^{-1}\right)$
\end{tabular}

${ }^{\alpha}$ Nitrogen fertilization was adjusted: $170 \mathrm{~kg} \mathrm{~N}^{-1}$ in the fallow treatment, 140 in vetch and 190 in barley in 2014; and $150 \mathrm{~kg} \mathrm{~N} \mathrm{ha}^{-1}$ in the fallow treatment, 110 in vetch and 196 in barley in 2016.

$\beta$ In 2015, sunflower biomass values refer to the head dry biomass.

\subsubsection{Field measurements, soil sampling and analysis}

The soil samples were taken after terminating the CC each two years since March 2008. Three cores from each plot were collected from 0-5 cm and 5-20 cm depths. Half of each composed sample, moist field sub-sample was passed through a $2 \mathrm{~mm}$ sieve and stored at $4^{\circ} \mathrm{C}$ until enzymatic and microbial biomass carbon analyses and half was air-dried, sieved (2-mm) and kept at room temperature for the rest of determinations.

Soil respiration was determined by measuring the $\mathrm{CO}_{2}$ flux directly on the soil surface in six points in each plot during the soil sampling years with an Environmental Gas Monitor chamber (SRC-1, EGM-4; PP Systems, Hitchin, U.K.). A metallic chamber (15 cm tall and $10 \mathrm{~cm}$ in diameter) was placed on the soil and measured the $\mathrm{CO}_{2}$ concentrations and soil moisture. Soil temperature was also 
recorded by placing a digital soil thermometer at a $5 \mathrm{~cm}$ depth near the chamber during the time of $\mathrm{CO}_{2}$ measurements.

The $\beta$-glucosidase activity was determined by Strobl et al. (1996) using salicin as substrate. The $\rho$-nitrophenyl-N-acetyl- $\beta$-D-glucosaminide substrate was used to test $\beta$-glucosaminidase (Parham and Deng, 2000). The dehydrogenase activity was assayed using 2- $\rho$-iodophenyl-3- $\rho$-nitrophenyl-5 phenyltetrazolium chloride (INT) as substrate and incubating for $20 \mathrm{~h}$ at $25^{\circ} \mathrm{C}$ (García et al., 1993). The urease activity was determined by Kandeler et al. (1999) measuring the release of ammonium extracted with $2 \mathrm{M} \mathrm{KCl}$ solution. The alkaline phosphatase and arylsulphatase were determined with $\rho$-nitrophenyl phosphate (Tabatabai and Bremner, 1969) and potassium $\rho$-nitrophenyl sulfate (Tabatabai and Bremner, 1970) as substrate respectively. The phosphatase and arylsulphatase were analyzed only in 2014 and 2016 due to the good response from the above enzymatic activities in the previous years. All enzymatic activities were assayed in duplicate with one control from 2010 until 2016, every two years.

The $\mathrm{C}_{\text {mic }}$ was estimated by the substrate-induced respiration (SIR) method (Anderson and Domsch, 1978). Soil pH was determined in deionized water (1:2.5 soil/water ratio). The $\mathrm{C}_{\text {mic }}$ and $\mathrm{pH}$ were measured from 2010, every two years. Total organic carbon was measured by dichromate oxidation and tritation with ferrous ammonium sulphate Walkey-Black method (Nelson and Sommers, 1996). The easily extractable and total glomalin reactive soil proteins (EE-GRSP and GRSP, respectively) were determined by Wright and Upadhyaya (1998). The EE-GRSP was extracted with $20 \mathrm{mM}$ sodium citrate, $\mathrm{pH} 7.0$ by autoclaving at $121{ }^{\circ} \mathrm{C}$ for 30 min and GRSP with $50 \mathrm{mM}$ sodium citrate at pH 8.0 and $121{ }^{\circ} \mathrm{C}$ in sequential cycles of $1 \mathrm{~h}$. Total organic carbon and glomalin fractions were measured from 2008 until 2016, every two years. Results were based on the oven-dried weight of the soil.

\subsubsection{Statistical analysis}

Statistical analyses were carried out using Statgraphics Centurion XVII, and the results were expressed as mean values. Significant differences between treatments (barley, vetch, fallow), years and their interaction were shown by LSD 
test at $\mathrm{p}<0.05$. Multifactorial analysis of variance (ANOVA) was used to assess spatial variability of all parameters for each individual treatment and year. Data normality was tested prior to analysis. Variables that did not have a normal distribution were analyzed with non-parametric tests: Kruskal-Wallis ANOVA for variance analysis and Mann-Whitney $U$ post hoc test for comparison of mean values. A correlation matrix of different properties was based on Pearson correlation coefficients. Data were studied independently for each soil depth.

\subsection{RESULTS}

The enzymatic activities enhanced in both CC treatments particularly in the superficial layer and also were affected by the time since 2010 (Table 1.2; Fig. 1.2). The $\beta$-glucosidase activity improved after barley compared with fallow in 2012 and after both CC since 2014 at 0-5 cm (Fig. 1.2A). However, in the second layer only the vetch treatment had higher $\beta$-glucosidase activity than the fallow in the last years (2014 and 2016). There was an interaction between treatments and year in this enzyme. The $\beta$-glucosaminidase activity was greater after both $\mathrm{CC}$ in all years except in 2012 that was only barley at 0-5 cm (Fig. 1.2B). Both CC increased dehydrogenase activity in 2012 and 2016 in the first depth and also in 2016 in the second layer (Fig. 1.2C). Dehydrogenase activity increased over time. Urease activity only showed higher results in the vetch treatment since 2014 year on (Fig. 1.2D). This enzyme was significantly higher in the last year of the experiment than in 2010 and 2012. The higher alkaline phosphatase activity was found in the vetch

Table 1.2. Effect of cover crop treatments and years on enzymatic activities and microbial biomass carbon $\left(\mathrm{C}_{\min }\right)$ at both depths.

\begin{tabular}{|c|c|c|c|c|c|c|c|c|c|}
\hline Depth $(\mathrm{cm})$ & Factor & $\beta G$ & NAG & $\mathrm{DH}$ & Ure & AlP & Aryl & $\mathrm{C}_{\text {mic }}$ & $\mathrm{pH}$ \\
\hline \multicolumn{10}{|l|}{$0-5$} \\
\hline & Treatment & $* * *$ & $* * *$ & $* * *$ & ns & $*$ & $* *$ & $* * *$ & $* * *$ \\
\hline & Year & ns & $*$ & $* * *$ & $* * *$ & $* *$ & $* *$ & $* *$ & $* * *$ \\
\hline & $\mathrm{T} \times \mathrm{Y}$ & ns & ns & ns & ns & ns & ns & ns & ns \\
\hline \multicolumn{10}{|l|}{$5-20$} \\
\hline & Treatment & ns & ns & $* * *$ & $*$ & ns & ns & ns & $* *$ \\
\hline & Year & $* * *$ & $* *$ & $* * *$ & $*$ & ns & ns & $* * *$ & $* * *$ \\
\hline & $\mathrm{T} \times \mathrm{Y}$ & $*$ & ns & ns & ns & ns & ns & ns & ns \\
\hline
\end{tabular}

$\beta$-Glucosidase $(\beta \mathrm{G}), \beta$-glucosaminidase $(\mathrm{NAG})$, dehydrogenase $(\mathrm{DH})$, urease (Ure), alkaline phosphatase (AlP) and aylsulphatase (Aryl) activities and microbial biomass carbón $\left(\mathrm{C}_{\text {mic }}\right)$.*: $\mathrm{p}<$ 0.05 ; $^{* *}$ p $<0.01{ }^{* * *}: \mathrm{p}<0.001$; ns: not significant. 
treatment only in 2014 at $0-5 \mathrm{~cm}$ (Fig. 1.2E). Nevertheless, the arylsulphatase enzyme enhanced after both CC in both years in the superficial depth and also in the vetch treatment at 5-20 cm (Fig. 1.2F). The arylsulphatase activity was lower in 2016 compared with 2014. The $\mathrm{C}_{\text {mic }}$ increased in both CC treatments in 2012 and only in barley in 2016 at $0-5 \mathrm{~cm}$ (Fig. 1.3A). The pH was significantly lower in the first depth, decreasing by CC incorporation only at 0-5 cm (Fig. 1.3B).
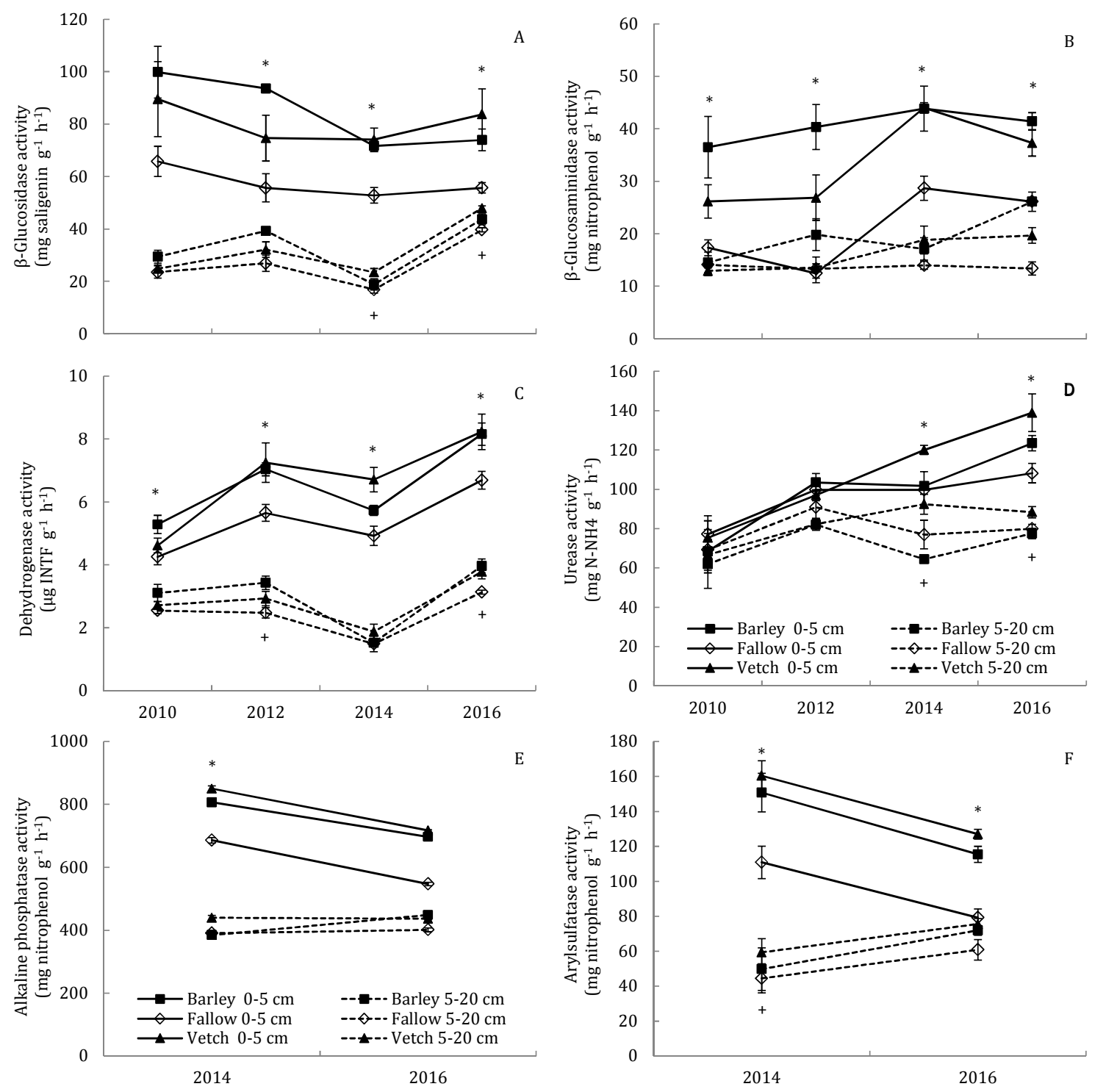

Fig. 1.2. Enzymatic activities of $\beta$-glucosidase (A), $\beta$-glucosaminidase (B), dehydrogenase (C) and urease (D) in 2010, 2012, 2014 and 2016 and alkaline phosphatase (E) and arylsulphatase (F) in 2014 and 2016. ${ }^{*}$ and + indicate significant differences among treatments (LSD or Mann-Whitney, at $\mathrm{P}>0.05$ ) at $0-5 \mathrm{~cm}$ and $5-20 \mathrm{~cm}$, respectively. Vertical bars represent standard errors. 


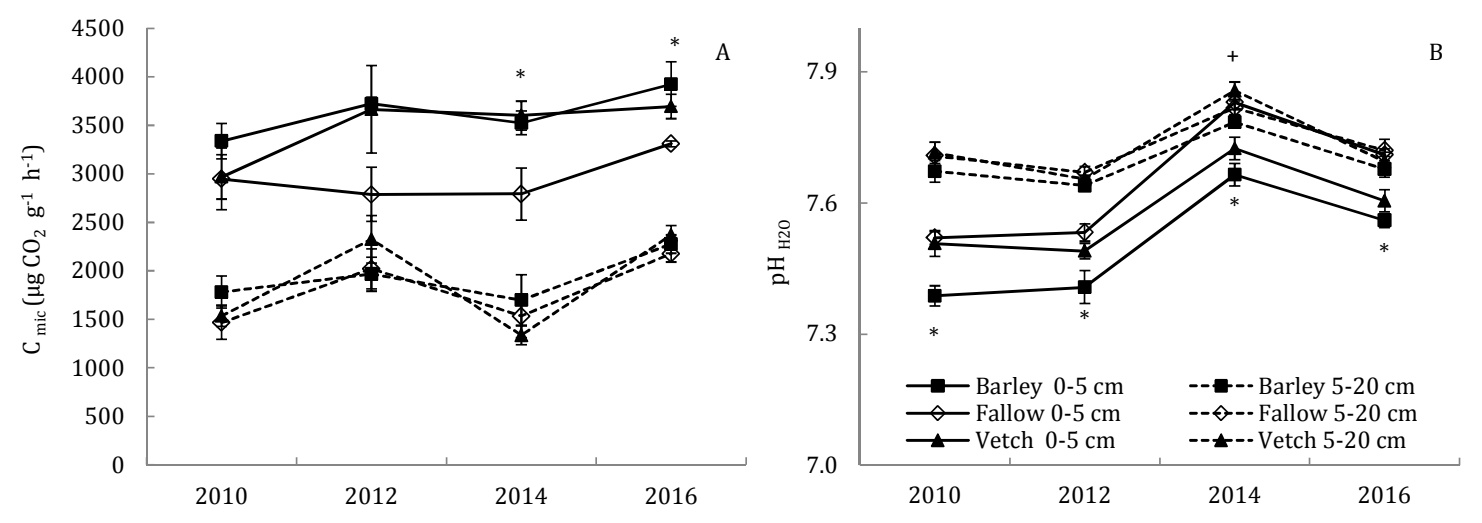

Fig. 1.3. Microbial biomass carbon $\left(\mathrm{C}_{\mathrm{mic}}\right)$ and $\mathrm{pH}_{\mathrm{H} 2 \mathrm{O}}$ in $2010,2012,2014$ and $2016 .{ }^{*}$ and ${ }^{+}$indicate significant differences between treatments (LSD at P > 0.05) at 0-5 cm and 5-20 cm, respectively.

The EE-GRSP in the barley treatment was higher compared with the vetch and fallow in 2008 and 2010 (Table 1.3; Fig. 1.4A). In the next two sampling dates, vetch increased the EE-GRSP content being intermediate. In 2016 both CC treatments showed greater EE-GRSP than fallow. Higher GRSP contents were obtained in barley in 2008 and 2010 at 0-5 cm, but since 2012 both CC improved the total glomalin content (Fig. 1.4B). In general, the easily and total glomalin content increased in the last years of the trial compared with 2008. From 2012 on, TOC showed significant differences among treatments and years (Fig. 1.4C). Both CC increased TOC amounts respect to fallow in 2012 and 2016, and only barley in 2014.

Table 1.3. Effect of cover crop treatments and years on easily extractable and total glomalin related soil protein (EE-GRSP and GRSP) and total organic carbon (TOC), at both depths.

\begin{tabular}{ccccc}
\hline Depth $(\mathrm{cm})$ & Factor & EE-GRSP & GRSP & TOC \\
\hline $0-5$ & & & & \\
& Treatment & $* * *$ & $* * *$ & $* * *$ \\
& Year & $* * *$ & $* * *$ & $* * *$ \\
& T x Y & ns & ns & ns \\
$5-20$ & & & & \\
& Treatment & $*$ & $* *$ & $* *$ \\
& Year & $* * *$ & $* * *$ & $\mathrm{~ns}$ \\
& T x Y & ns & ns & ns \\
\hline$*: \mathrm{p}<0.05 ;{ }^{* *}: \mathrm{p}<0.01 ;{ }^{* * *}: \mathrm{p}<0.001 ;$ ns: not significant.
\end{tabular}

The introduction of different CC increased TOC content and, in addition, the change to minimum tillage achieved an improvement of organic carbon in the fallow treatment. For example at 0-5 cm, barley increased 39\% from 2008 to 2016, 
vetch $36 \%$ and $25 \%$ fallow. The soil respiration measured on the soil surface was affected by treatment $(\mathrm{P}<0.001)$ and by year $(\mathrm{P}<0.001)$ (Fig. 1.5$)$. There was also a significant interaction between both factors $(\mathrm{P}<0.01)$. Barley obtained the highest $\mathrm{CO}_{2}$ content in 2010 compared with fallow. However, from 2012 on both CC increased the soil respiration. Over the time, vetch and fallow treatments increased the soil respiration, but not the barley that only increased respiration in 2012 .

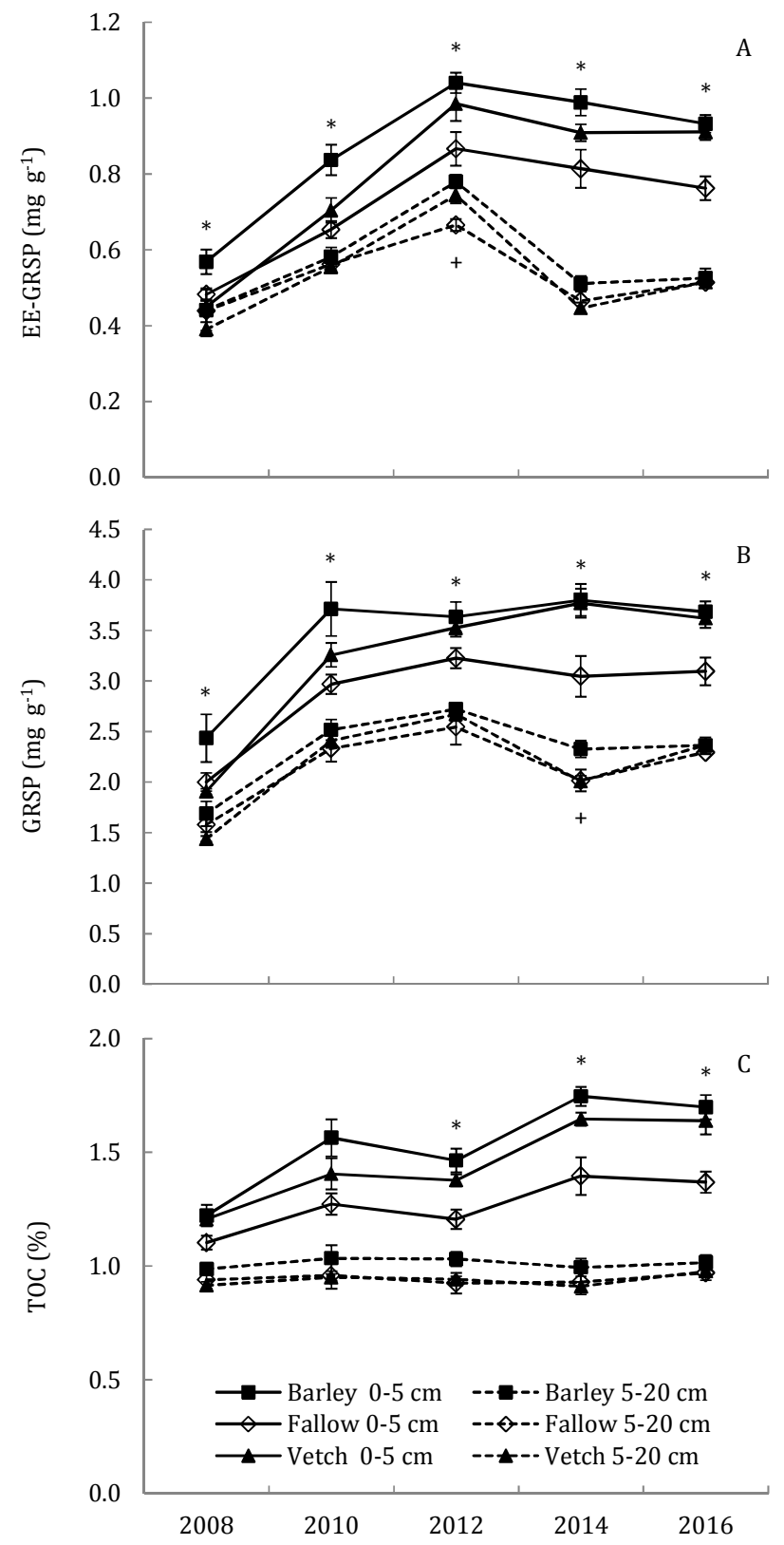

Fig. 1.4. Easily extractable and total glomalin-related soil protein (EE-GRSP and GRSP) and total organic carbon (TOC) from 2008 to 2016. * and + indicate significant differences between treatments (LSD or Mann-Whitney, at P > 0.05) at 0-5 cm and 5-20 cm, respectively. Vertical bars represent standard errors. 


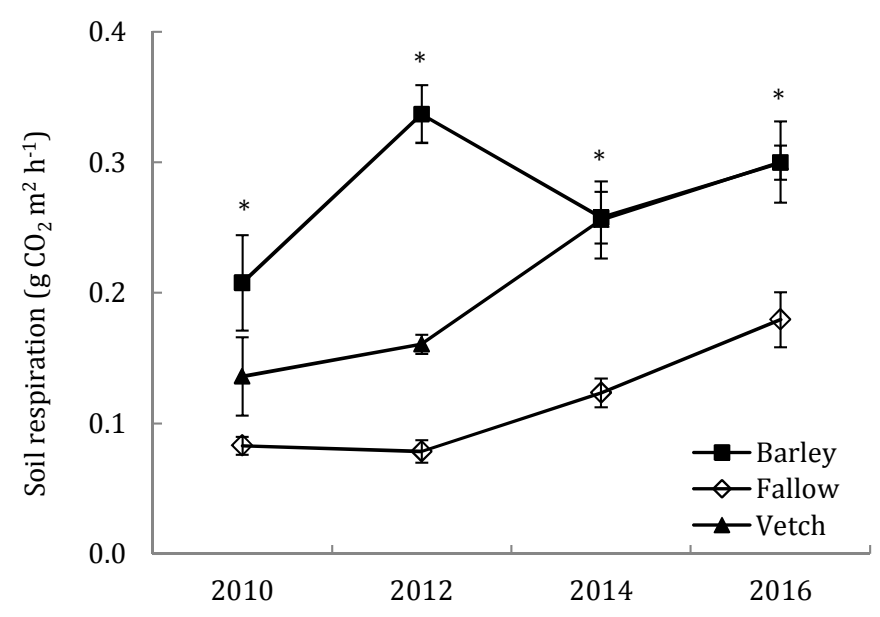

Fig. 1.5. Soil respiration from 2010 to $2016 .{ }^{*}$ indicates significant differences between treatments (LSD at $\mathrm{P}>0.05$ ). Vertical bars represent standard errors.

There were positive and strong correlations among enzyme activities, TOC, easily and total glomalin fractions and soil respiration, except with the Urease activity in the first soil depth in 2010 (Table 1.4). The $\mathrm{C}_{\text {mic }}$ was not correlated with any variable this year. In the second depth (Table 1.5), most of the enzymatic activities were correlated each other and TOC had relationships with the other biological properties, except with $\mathrm{C}_{\text {mic }}$. In 2012, the sixth year of the field experiment the relationships were kept constant compared to 2010 (Table 1.6 and 1.7) with the appearance of new correlations between $C_{\text {mic }}$ and the other biological parameters in the first $5 \mathrm{~cm}$ depth. In 2016, all the correlations observed in previous years remained strong and, in addition, the relationship of urease activity with most of the other parameters became significant (Table 1.8). In the second layer, most of the correlations observed in 2010 vanished with time (Table 1.9). 
Table 1.4. Correlation coefficients between biological properties and total organic carbon in 2010 $(0-5 \mathrm{~cm})$.

\begin{tabular}{ccccccccc}
\hline & $\beta G$ & NAG & DH & Ure & C $_{\text {mic }}$ & EE-GRSP & GRSP & TOC \\
\hline NAG & $0.87^{* * *}$ & & & & & & & \\
DH & $0.69^{*}$ & ns & & & & & & \\
Ure & ns & ns & ns & & & & & \\
C mic & ns & ns & ns & ns & & & & \\
EE-GRSP & $0.81^{* *}$ & $0.89^{* * *}$ & $0.58^{*}$ & ns & ns & & & \\
GRSP & $0.84^{* * *}$ & $0.98^{* * *}$ & ns & ns & ns & $0.90^{* * *}$ & & \\
TOC & $0.86^{* * *}$ & $0.90^{* * *}$ & $0.76^{* *}$ & ns & ns & $0.91^{* * *}$ & $0.95^{* * *}$ & \\
SR & $0.87^{* * *}$ & $0.87^{* * *}$ & $0.69^{*}$ & ns & ns & $0.88^{* * *}$ & $0.86^{* * *}$ & $0.88^{* * *}$ \\
\hline
\end{tabular}

Enzyme activities of $\beta$-glucosidase $(\beta G), \beta$-glucosaminidase (NAG), dehydrogenase (DH), urease (Ure), microbial biomass carbon ( $\mathrm{Cmic}$ ), easily extractable and total glomalin reactive soil proteins (EE-GRSP and GRSP), total organic carbon (TOC) and soil respiration (SR). ns: not significant. *, ${ }^{* *}, * * *$, significant at $\mathrm{P}<0.05,0.01$ and 0.001 , respectively.

Table 1.5. Correlation coefficients between biological properties and total organic carbon in 2010 $(5-20 \mathrm{~cm})$.

\begin{tabular}{ccccccccc}
\hline & $\beta G$ & NAG & DH & Ure & C $_{\text {mic }}$ & EE-GRSP & GRSP & TOC \\
\hline NAG & $0.66^{*}$ & & & & & & & \\
DH & $0.79^{* *}$ & $0.68^{*}$ & & & & & & \\
Ure & $-0.59^{*}$ & ns & ns & & & & & \\
C $m$ mic & ns & ns & ns & ns & & & & \\
EE-GRSP & $0.68^{*}$ & ns & $0.74^{* *}$ & ns & ns & & & \\
GRSP & $0.77^{* *}$ & ns & $0.72^{* *}$ & $-0.59^{*}$ & ns & $0.71^{*}$ & & \\
TOC & $0.85^{* *}$ & $0.67^{*}$ & $0.68^{*}$ & $-0.71^{*}$ & ns & $0.73^{* *}$ & $0.94^{* * *}$ & \\
\hline
\end{tabular}

ns: not significant. ${ }^{*}, * *, * *$, significant at $P<0.05,0.01$ and 0.001 , respectively.

Table 1.6. Correlation coefficients between biological properties and total organic carbon in 2012 $(0-5 \mathrm{~cm})$.

\begin{tabular}{ccccccccc}
\hline & $\beta G$ & NAG & DH & Ure & C $_{\text {mic }}$ & EE-GRSP & GRSP & TOC \\
\hline NAG & $0.85^{* * *}$ & & & & & & & \\
DH & $0.80^{* *}$ & ns & & & & & & \\
Ure & ns & ns & ns & & & & & \\
C mic & $0.80^{* *}$ & $0.69^{*}$ & $0.79^{* *}$ & ns & & & & \\
EE-GRSP & $0.92^{* * *}$ & $0.68^{*}$ & $0.76^{* *}$ & ns & $0.78^{* *}$ & & & \\
GRSP & $0.76^{* *}$ & ns & ns & ns & $0.61^{*}$ & $0.90^{* * *}$ & & \\
TOC & $0.87^{* * *}$ & $0.76^{* *}$ & $0.74^{* *}$ & ns & $0.65^{*}$ & $0.84^{* * *}$ & $0.73^{* *}$ & \\
SR & $0.75^{* *}$ & $0.88^{* * *}$ & ns & ns & ns & ns & ns & $0.74^{* *}$ \\
\hline
\end{tabular}

ns: not significant. ${ }^{*}, * *, * * *$, significant at $P<0.05,0.01$ and 0.001 , respectively. 
Table 1.7. Correlation coefficients between biological properties and total organic carbon in 2012 $(5-20 \mathrm{~cm})$.

\begin{tabular}{cccccccc}
\hline & $\beta G$ & NAG & DH & Ure & C $_{\text {mic }}$ & EE-GRSP & GRSP \\
\hline NAG & ns & & & & & & \\
DH & $0.70^{*}$ & $0.73^{* *}$ & & & & & \\
Ure & $n s$ & ns & ns & & & & \\
C mic & ns & ns & ns & ns & & & \\
EE-GRSP & $0.85^{* * *}$ & ns & $0.69^{*}$ & ns & ns & & \\
GRSP & ns & ns & ns & ns & ns & $0.78^{* *}$ & \\
TOC & $0.70^{*}$ & ns & ns & ns & ns & ns & ns \\
\hline
\end{tabular}

ns: not significant. ${ }^{* * *}, * * *$, significant at $P<0.05,0.01$ and 0.001 , respectively.

Table 1.8. Correlation coefficients between biological properties and total organic carbon in 2016 $(0-5 \mathrm{~cm})$.

\begin{tabular}{|c|c|c|c|c|c|c|c|c|c|c|}
\hline & $\beta G$ & NAG & DH & Ure & AlP & Aryl & $\mathrm{C}_{\text {mic }}$ & EE-GRSP & GRSP & TOC \\
\hline NAG & $0.74 * *$ & & & & & & & & & \\
\hline DH & $0.62^{*}$ & $0.77^{* *}$ & & & & & & & & \\
\hline Ure & $0.65^{*}$ & ns & ns & & & & & & & \\
\hline AlP & $0.64^{*}$ & $0.60^{*}$ & ns & $0.83^{* * *}$ & & & & & & \\
\hline Aryl & $0.91^{* * *}$ & $0.84^{* * *}$ & $0.77^{* *}$ & $0.67^{*}$ & $0.72^{* *}$ & & & & & \\
\hline $\mathrm{C}_{\text {mic }}$ & ns & $0.61^{*}$ & $0.60^{*}$ & ns & $0.58^{*}$ & $0.63^{*}$ & & & & \\
\hline EE-GRSP & $0.77^{* *}$ & $0.89 * * *$ & $0.66^{*}$ & $0.67^{*}$ & $0.77^{* *}$ & $0.87^{* * *}$ & $0.66^{*}$ & & & \\
\hline GRSP & $0.79 * *$ & $0.85^{* * *}$ & $0.58^{*}$ & $0.70^{*}$ & $0.84^{* * *}$ & $0.87^{* * *}$ & $0.69 *$ & $0.98^{* * *}$ & & \\
\hline TOC & $0.82 * *$ & $0.90^{* * *}$ & $0.72^{* *}$ & $0.60 *$ & $0.68^{*}$ & $0.87^{* * *}$ & $0.65^{*}$ & $0.98^{* * *}$ & $0.95^{* * *}$ & \\
\hline SR & ns & $0.71^{* *}$ & $0.60^{*}$ & $0.60^{*}$ & $0.58^{*}$ & $0.66^{*}$ & $0.71^{* *}$ & $0.71^{* *}$ & $0.71^{* *}$ & $0.64^{*}$ \\
\hline
\end{tabular}

Table 1.9. Correlation coefficients between biological properties and total organic carbon in 2016 $(5-20 \mathrm{~cm})$.

\begin{tabular}{cccccccccc}
\hline & $\beta G$ & NAG & DH & Ure & AlP & Aryl & C $_{\text {mic }}$ & EE-GRSP & GRSP \\
\hline NAG & ns & & & & & & & & \\
DH & $0.62^{*}$ & ns & & & & & & & \\
Ure & $0.67^{*}$ & ns & ns & & & & & & \\
AlP & ns & ns & ns & ns & & & & & \\
Aryl & ns & ns & ns & ns & $0.96^{* * *}$ & & & & \\
C & $0.76^{* *}$ & ns & ns & ns & $0.58^{*}$ & $0.62^{*}$ & & & \\
EE-GRSP & ns & ns & ns & ns & ns & ns & ns & & \\
GRSP & $0.62^{*}$ & ns & $0.58^{*}$ & ns & ns & ns & $0.69^{*}$ & $0.81^{* *}$ & \\
TOC & ns & ns & ns & ns & ns & ns & ns & $0.82^{* *}$ & $0.64^{*}$ \\
\hline
\end{tabular}

ns: not significant. ${ }^{*}, * *, * * *$, significant at $P<0.05,0.01$ and 0.001 , respectively. 


\subsection{DISCUSSION}

Both biological and chemical parameters were affected by cover cropping in the first 8 years, mostly in the upper layer $(0-5 \mathrm{~cm}$ depth). These results are partially agreed with Gil-Sotres et al. (2005) who reported that soil biological characteristics are more sensitive to management shifts than physic-chemical properties, especially in short-term trials. However, in our study the combination of $\mathrm{CC}$ residues left on the soil surface and the switch to minimum tillage enhanced the TOC content in the sixth year.

Overall, enzyme activities increased after CC, particularly at the first $5 \mathrm{~cm}$ depth, although they did not follow any apparent pattern that could explain all changes over the years. $\beta$-Glucosaminidase and dehydrogenase activities were the enzymes that responded more rapidly to CC establishment, being the $\beta$ glucosaminidase activity already enhanced in both CC treatments at $0-5 \mathrm{~cm}$ by 2010. Another enzymatic activity that also represents the shifts in soil management was the $\beta$-glucosidase. The barley treatment had the highest $\beta$ glucosidase activity in 2012 and from that year on both CC enhanced the $\beta$ glucosidase in the first $5 \mathrm{~cm}$ of soil. Those improvements in the enzyme activities by CC are in agreement with studies such as Bandick and Dick (1999), AcostaMartinez et al. (2003) and Chavarría et al. (2016). Similarly to our results, Balota et al. (2014a) also found higher levels of phosphatase activity after vetch CC and higher arylsulphatase activity after all of CC used.

The enzymatic activities were higher in the first $5 \mathrm{~cm}$ depth in most of the treatments compared with the second depth, because of the greater residue biomass, root exudates and aeration in the upper layer. The largest increments were observed in the $\beta$-glucosidase enzyme. These results agreed with Melero et al. (2009) and De la Horra et al. (2003) which also found that due to the involvement of this enzyme with the transformation of organic matter, the superficial layer had higher $\beta$-glucosidase activity.

The variations in the fertilization doses over the years might have affected some enzymes such as $\beta$-glucosidase, dehydrogenase and urease activities (Ajwa et 
al., 1999). In 2014 after the period of no fertilization (2011-2012), those enzymes had a light decrease or did not show any increase compared with the results in 2012 , especially in the barley treatments. In 2014, $\beta$-glucosidase activity after barley decreased by 23\% and dehydrogenase by 19\% compared with 2012 . However, the vetch treatment had the highest values in $\beta$-glucosaminidase, dehydrogenase and urease activity in 2014. The years with no synthetic N fertilizers and the extra source of $\mathrm{N}$ from vetch residues enhanced those enzymes compared with the other treatments. Indeed urease activity started to increase after the two campaigns with no fertilization. These results seems to be in agreement with the findings by Dick et al. (1988) and Bandick and Dick (1999) who showed that the application of ammonia-based fertilizer reduced the urease activity, due to the suppression of the enzyme synthesis and it was stimulated when nutrient availability was reduced (Eivazi et al., 2003). In addition, a decrease in the urease activity was found by Balezentiene and Klimas (2009) after a mineral fertilization application. After the period with adjusted fertilization, in 2016 the barley treatment increased the enzymatic activities again compared to fallow in the shallowest soil layer, except in urease and alkaline phosphatase. Overall, the barley CC stimulated the enzymatic activities while there was fertilization.

Over the years, we expected an increase of the enzymatic activities by CC, but only dehydrogenase and urease enzymes showed clearly this effect. The accumulation of organic matter on the top layer in the CC treatments might have contributed to this stimulation but also stabilized the other soil enzymes due to the lack of soil disruption by minimum tillage (Nivelle et al., 2016). In addition, the fallow treatment incremented the $\beta$-glucosaminidase and dehydrogenase activities from 2010 to 2016. The switch to minimum tillage in 2006 also had a positive effect on the treatment with winter fallow, which is likely due to the higher nutrient availability and the less oxidizing environment.

Relationships between soil parameters appeared in the first $5 \mathrm{~cm}$ depth and disappeared in the second layer with the passing of the years. Most of the correlations were found also in other long-term experiments (Acosta-Martinez et al., 2003; Balota et al., 2014a; Melero et al., 2009). The accumulation of organic matter in the upper soil layer by CC and minimum tillage, and also the contribution 
of the main crops (root exudates, decomposition of roots and crop residues) stimulated the microbial community and enhanced the enzymes activity (Balota et al., 2004). In 2010, the urease activity was the only enzyme that was not correlated with any other biological parameter, not even with TOC (Roscoe et al., 2000). This lack of correlation might be explained by the suppression of this enzyme due to the $\mathrm{N}$ fertilization (Bandick and Dick, 1999). However, after the period of no fertilization (2011-2012), urease activity started to show correlations with some other enzymes.

Both glomalin fractions, EE-GRSP and GRSP, were enhanced by cover cropping since the second year of the long-term experiment. These findings are in agreement with other rotations that included CC (Stetson et al., 2012; Wright and Anderson, 2000) and particularly the ones with grasses (Balota et al., 2014a; Rillig et al., 2002). The glomalin contents showed early increments, therefore, they might be considered also as a sensitive biological parameter. Similarly to the TOC contents, both glomalin fractions increased their levels from 2008 to 2016, participating in the soil $\mathrm{C}$ sequestration. The relationships between glomalin contents and increments in soil aggregation will translate into an enhancement of soil structure in the CC treatments (Wu et al., 2014).

The $\mathrm{C}_{\text {mic }}$ did not show any difference between treatments during the first years of the experiment, and after 2012 (6 years after introducing the CC) it was enhanced by both CC treatments in the first $5 \mathrm{~cm}$ of soil. Our results did not agree with short-term studies such as Lagomarsino et al. (2009), Zhu et al. (2012) or Tejada et al. (2008) who found improvements of microbial biomass C after crop residues incorporation. However, the results agree with Balota et al. (2014a) who found increments in $\mathrm{C}_{\text {mic }}$ with the use of $\mathrm{CC}$ in a long-term experiment. AcostaMartínez et al. (2011) showed that the enhancement of microbial biomass contributed to a stimulation of enzyme activities. Nevertheless, four years after the beginning of our study (in 2010) the CC residues did not show any effect in the C labile portion and there was a lack of correlations between $\mathrm{C}_{\text {mic }}$ and the other parameters. In 2012, six years after introducing the $\mathrm{CC}$ the $\mathrm{C}_{\text {mic }}$ started to obtain positive relationships with the enzyme activities and TOC $\left(0.80^{* *}\right.$ with $\beta$ - 
glucosidase, $0.69^{*} \beta$-glucosaminidase, $0.79^{* *}$ dehydrogenase and $0.65^{*}$ with TOC). The enhancements of $\beta$-glucosaminidase and dehydrogenase activities were already observed in the CC treatments in 2010 , before $C_{\text {mic }}$ showed significant differences between treatments. Therefore, these enzymatic activities were an earlier indicator of changes in the microbial population and soil conditions than $C_{\text {mic }}$ (Eivazi et al., 2003). From the other biological parameters, the EE-GRSP and GRSP were also sensitive parameters as the enzyme activities, showing differences by CC in 2010 .

The TOC improvements in the first $5 \mathrm{~cm}$ depth during the study confirmed the importance of introducing CC in the rotations with degraded soils in Mediterranean areas (Acosta-Martinez et al., 2007). There are studies which showed the necessity of long term experiments to obtain benefits in the TOC contents. However, in our study higher TOC were found in the CC treatments since 2012 that are in agreement with other short term experiments (Nivelle et al., 2016; Veenstra et al., 2007). Particularly, Villamil et al. (2006) and Mazzoncini et al. (2011) obtained higher SOM in crop rotations that included legume CC and not grasses. One of the reasons of these differences might be because of the different mineralization ratios between legume and grass or the higher biomass yielding capacity by legume, respectively. Our improvements in both CC treatments contradicted those findings since we also found higher TOC contents in the barley monoculture.

The increment of TOC in the three treatments, even in fallow, with the passing of the time was also due to the switch to minimum tillage. From 2008 until 2016, there were increases of 39\% after barley, 36\% after vetch and $25 \%$ after fallow. Some studies showed that the combination of no tillage and use of CC is necessary to increase the TOC content (Nivelle et al., 2016; Veenstra et al., 2007). However, in our study, reducing tillage intensity was sufficient to increase the TOC content in the fallow treatment in the first $5 \mathrm{~cm}$ depth throughout the study. The benefits of both conservative practices were effective in the carbon accumulation and also its stabilization, improving the soil structure, soil aeration and water holding capacity (Hartwig and Ammon, 2002). The increase of glomalin fractions and their strong and positive correlations with TOC also confirmed the 
contribution of this parameter to the soil aggregate stability (Wright and Upadhyaya, 1998).

The comparison between $\mathrm{C}_{\text {mic }}$ and TOC parameters showed that both parameters responded positively in the same year to the CC establishment (six years after the onset of the trial). This contradicts the affirmation that $\mathrm{C}_{\text {mic }}$ is a more sensitive parameter than TOC, at least under our field conditions. The explanation might be in the slight increments in TOC by the minimum tillage between 2008 and 2012 that contributed to the relationships found with the biological parameters in 2010. By the contrary, $\mathrm{C}_{\text {mic }}$ did not show any correlation until 2012, confirming no relation with any variable until the CC effect was significant.

In the second depth, the no differences in TOC found in our study are in agreement with Acosta-Martinez et al. (2007) who did not obtain any effect for the 5-15 cm depth. The long-term experiment (15 years) by Mazzoncini et al. (2011) had higher TOC levels in the treatments with legume CC than control $(10-30 \mathrm{~cm})$. The disparity of results after $5 \mathrm{~cm}$ depth might be the result of a difference in the biomass returned (main crop and CC residues) to the soil between the treatments. In our experiment, although there were not increments in maize biomass over the years, there were differences between CC biomass (Gabriel et al., 2016; Gabriel and Quemada, 2011). It seems that the CC did not supply C, either as roots or above ground residues, to increase the TOC in the second layer in systems with minimum tillage.

The positive relationships found between TOC content with enzymatic activities, mainly in the soil upper layer $(0-5 \mathrm{~cm})$ showed the benefits of improving the biological soil quality by cover cropping and the subsequent organic carbon stabilization. These correlation between biological and physical parameters were obtained in other studies (Acosta-Martinez et al., 2003).

Soil respiration is affected by the crop species, environmental conditions and soil properties (DeForest et al., 2006; Mancinelli et al., 2013). In our study, the effect of CC residues on the soil surface increased the soil respiration. In addition, 
the differences in the biological properties associated with the two CC species influenced in a different way the soil respiration, i.e. the barley treatment enhanced earlier soil respiration (2010) than vetch (2012). The highest soil respiration in the treatment with a grass is in accordance with Sainju et al. (2008) when the rotations with rye and barley crops had higher soil respiration than with winter pea.

\subsection{CONCLUSIONS}

Overall, the CC incorporation during a long-term experiment increased the biological parameters over the time. The barley $\mathrm{CC}$ had the largest effect in most of the parameters and the vetch treatment had higher urease activity compared with the other treatments. The reduction of soil disturbance due to the shift to minimum tillage improved some biological parameters, such as dehydrogenase and urease activities and both glomalin fractions, even in the fallow treatment. The EE-GRSP and GRSP obtained positive increments by CC in 2008, two years after the onset of the experiment. Therefore, they might be considered also sensitive parameters as $\beta$-glucosaminidase and dehydrogenase activities, which showed the effect in the fourth year.

Total organic carbon obtained larger contents with CC treatments from the sixth year. Compared with the low organic matter content at the beginning of the

study, CC incorporation and minimum tillage together permitted an increase in the accumulation of $\mathrm{C}$, but only in the first $5 \mathrm{~cm}$ of the soil.

The increments in the number of correlations with the passing of the years contributed to the improvement and stabilization of biological activity in the soil, especially in the upper layer. These improvements and relationships between all parameters confirmed the positive impacts of sustainable agricultural practices on nutrient cycling and soil quality. 
Chapter 2

\section{Arbuscular mycorrhizal fungal activity responses to winter cover crops in a sunflower and maize cropping system ${ }^{1}$}

${ }^{1}$ García-González, I., Quemada, M., Gabriel, J.L., Hontoria, C., 2016. Arbuscular mycorrhizal fungal activity responses to winter cover crops in a sunflower and maize cropping system. Applied Soil Ecology 102, 10-18. 



\subsection{INTRODUCTION}

Winter cover crops (CC) prevent soil erosion (Bowman et al., 2000), increase soil organic matter (Kuo et al., 1997) and reduce the leaching of nitrate and other nutrients (Gabriel et al., 2013), among other advantages. Another effect of CC is the enhancement of the inoculum level of the arbuscular mycorrhizal fungi (AMF) (Galvez et al., 1995), which may promote the health of the subsequent crop, the mineral nutrition, and the abiotic stress tolerance, as well as provide protection against pathogens and soil aggregation processes (Azcón-Aguilar and Barea, 1997; Jeffries et al., 2003; Lekberg and Koide, 2005; Van Der Heijden et al., 2006). Replacing the winter bare fallow with CC improves the conditions for AMF development by providing a host plant and a supply of organic carbon to these obligate symbionts (Kabir and Koide, 2002). However, in semiarid climates, the drier conditions generated by CC with respect to fallow (Gabriel et al., 2012) might be a limitation for the maintenance of potential AMF inoculum, affecting the process of colonization in the subsequent crop. Thus, the climatic and environmental factors could be more important than winter cover cropping on AMF development (Higo et al., 2014). The effect of CC on AMF has been evaluated in various temperate areas in the USA (Galvez et al., 1995; Kabir and Koide, 2002; White and Weil, 2010) northwestern Europe (Sorensen et al., 2005) and Asia (Deguchi et al., 2007; Higo et al., 2014). Limited information about CC and AMF is available from Mediterranean areas and semiarid conditions. In Italy, Njeru et al. (2014) reported a beneficial effect of CC on the AMF colonization of the subsequent organic maize crop. Other studies in the Mediterranean areas of SE Spain reported the effects of management practices on AMF (Alguacil et al., 2014), but most of the research is focused on natural ecosystems (Barea et al., 2011; Ortiz et al., 2015). Additional investigations in cropping systems under Mediterranean conditions are required to clarify whether the positive effect of $\mathrm{CC}$ on $\mathrm{AMF}$ is maintained through their mild and relatively dry winter conditions.

Most studies of the influence of management practices on AMF have focused on root colonization as a measurement of fungal abundance. In addition, some propagules as number of spores or extra-radical hyphal measurements are often 
determined to quantify the inoculum potential for infection. Especially the extraradical hyphal length determination would be a good option to measure the AMF abundance in the soil, due to the fact that not all AMF produce spores (Morton and Redecker, 2001) and that would result in a limitation to the methods of spore count. Compared with fallow conditions, CC increased the root colonization of the subsequent crop in a temperate climate, for example, in maize (Kabir and Koide, 2000, 2002; Lehman et al., 2012; White and Weil, 2010), leeks (Sorensen et al., 2005) and soybean (Higo et al., 2014). However, other crops, such as sunflower, that are typical in rotations in Mediterranean areas, have received no attention. Differences in colonized root length are likely to be observed after main crop planting, and they may disappear over time (Gavito and Miller, 1998; Sorensen et al., 2005); for this reason, sampling should be conducted in the early crop stages. At that time, AMF infection may be more important because it can be decisive in the success of the seedling establishment phase (Boswell et al., 1998). Therefore, the influence of the sampling date should be considered along with the effect of the CC on AMF.

Cover crops can affect other soil variables, such as glomalin, an insoluble and hydrophobic proteinaceous substance, which is a component of the hyphae and spore walls of AMF (Driver et al., 2005). Glomalin has a slow turnover rate (Steinberg and Rillig, 2003) and can accumulate in soils (Rillig et al., 2001b) where it enhances the stabilization of soil aggregates (Rillig and Mummey, 2006). While parameters traditionally used to measure AMF (root colonization or length of hyphae) are complex and time-consuming, some of the glomalin fractions, such as the glomalin-related soil proteins (GRSPs), are easily measured. Because studies found a positive correlation between GRSPs and parameters directly related to AMF (Bedini et al., 2007; Peng et al., 2013), GRSP might be used as a simple indicator of AMF. However, many studies found no relationship between the content of this protein and the AM fungal parameters (Lovelock et al., 2004b; Lutgen et al., 2003; Rillig et al., 2001a; Wright and Upadhyaya, 1999), which may call into question its ability to indicate AMF abundance. Glomalin is also of interest due to its role in microaggregate and macroaggregate formation and stabilization (Rillig and Mummey, 2006), contributing to the explanation of the positive effect of 
AMF on soil structure (Bronick and Lal, 2005). Because the percentage of waterstable aggregates (WSA) is an important physical indicator used to evaluate soil structure, it was included in this study to test the positive effects of CC on aggregation through AMF enhancement, as well as to examine its relationship with glomalin. Among all of the biological soil properties, enzyme activities are the most sensitive indicator of soil quality changes related to land use, soil management and environmental stress (Ekenler and Tabatabai, 2003). The enzymatic activity of $\beta$ glucosaminidase is responsible for degrading chitin, a major structural compound in insects and fungal cell walls that is abundant in the soil and plays a key role in $\mathrm{C}$ and N cycling (Wood et al., 1994). Some studies (Andersson et al., 2004; Miller et al., 1998; Reeslev et al., 2003) showed how the $\beta$-glucosaminidase activity was related to fungal biomass so that it could be used as a simple and sensitive indicator of soil fungal biomass.

The general objective of this study was to determine whether replacing the traditional winter fallow in Mediterranean areas with CC would enhance AMF activity. The specific objectives were as follows: i) to evaluate the CC effect on several variables related to AMF under two different main crops, sunflower and maize, and ii) to study the relationships among the variables directly and indirectly related to AMF. The directly related variables were the percentage of mycorrhizal colonization, the length of extra-radical mycelium and the number of AM fungal spores. The indirect variables were the soil content of the easily extractable fraction of the GRSP and $\beta$-glucosaminidase activity. Finally, the percentage of soil water-stable aggregates was selected as an indicator of the benefits of AMF to soil quality.

\subsection{MATERIALS AND METHODS}

\subsubsection{Study site and experimental design}

The study was conducted during two seasons (2011-12 and 2012-13) at La Chimenea Field Station $\left(40^{\circ} 03^{\prime} \mathrm{N}, 03^{\circ} 31^{\prime} \mathrm{W}, 550 \mathrm{~m}\right.$ a.s.l.) in the central Tajo River basin near Aranjuez (Madrid, Spain) in a trial established in 2006. The soil was classified as Typic Calcixerept (Soil Survey Staff, 2014) with the following top soil 
(0 - $20 \mathrm{~cm})$ properties in 2012: $\mathrm{pH}_{\text {water }}$ (1:2.5), 8.4; organic matter, $18 \mathrm{~g} \mathrm{~kg}^{-1}$; calcium carbonate, $157 \mathrm{~g} \mathrm{~kg}^{-1}$; sand $(2000-50 \mu \mathrm{m})$, silt $(50-2 \mu \mathrm{m})$ and clay $(<2 \mu \mathrm{m})$ content, 290, 420 and $290 \mathrm{~g} \mathrm{~kg}^{-1}$, respectively, and loam textural class. The climate of this area is Mediterranean semiarid (Papadakis, 1966). The mean annual temperature is $14.2{ }^{\circ} \mathrm{C}$, and the mean annual precipitation is $350 \mathrm{~mm}$. Measurements of temperature, humidity, radiation, and wind were recorded throughout the experimental period in a CR23X micrologger from Campbell Scientific (Logan, Utah, USA).

Twelve plots $\left(12 \times 12 \mathrm{~m}^{2}\right)$ were randomly distributed in four replications of three treatments: barley (Hordeum vulgare L., cv. Vanessa) and vetch (Vicia villosa L., cv. Vereda) as CC during the fall-winter period, with fallow as the control. The cover crops were broadcasted by hand over the stubble of the previous crop and covered with a shallow cultivator ( $\sim 5 \mathrm{~cm}$ depth) that passed over all of the plots in October (18/10/2011 and 05/10/2012). All of the plots were treated with one application of glyphosate 2\% (N-phosphonomethyl glycine) in March to terminate the CC. The main crop was sown in early spring over the chopped CC residue by direct sowing. The first year, sunflower (Helianthus annuus L., var. Sanbro) was sown (20/04/2012), and the second year, maize (Zea mays L., G-98 Pioneer) was sown (18/04/2013). The main crop was harvested in early autumn (sunflower on 12/09/2012 and maize on 07/10/2013). Water was uniformly applied using a sprinkler irrigation system $\left(12 \mathrm{~m} \times 12 \mathrm{~m}, 9.5 \mathrm{~mm} \mathrm{~h}^{-1}\right)$ according to crop evapotranspiration (ETc) requirements calculated by the FAO method (Allen et al., 1998). Additional details about the soil and the experimental site can be found in the literature (Gabriel and Quemada, 2011). Throughout the experiment, all plots received the same amount of synthetic fertilizer. From 2006 to 2011, ammonium nitrate (210 kg N ha-1) split into two applications when maize had 4 and 8 leaves, and before sowing the main crop $120 \mathrm{~kg} \mathrm{P} \mathrm{ha}^{-1}$ as triple superphosphate and 120 kg K ha-1 as potassium sulfate. Fertilization was suspended in 2012 and 2013. Cover crop residues remained in the field, whereas the maize and sunflower residues were removed from the experiment, leaving the same amount $(\approx 1000 \mathrm{~kg}$ $\mathrm{ha}^{-1}$ ) in all of the plots. A summary of the experimental history is shown in Table 2.1 . 
Table 2.1. Summary of the experiment history at La Chimenea field in Aranjuez (Madrid, Spain).

\begin{tabular}{ccccc}
\hline Campaign & Crop & Sowing & $\begin{array}{c}\text { Harvest or } \\
\text { CC killing }\end{array}$ & $\begin{array}{c}\text { Fertilization } \\
\left(\mathrm{kg} \mathrm{N}-\mathrm{P}_{2} \mathrm{O}_{5}-\mathrm{K}_{2} \mathrm{O} \mathrm{ha}^{-1}\right)\end{array}$ \\
\hline \multirow{2}{*}{$2006-07$} & Maize & $05 / 04 / 2006$ & $25 / 09 / 2006$ & $210-120-120$ \\
& CC/Fallow & $05 / 10 / 2006$ & $22 / 03 / 2007$ & - \\
\multirow{2}{*}{$2007-08$} & Maize & $17 / 04 / 2007$ & $08 / 10 / 2007$ & $210-120-120$ \\
& CC/Fallow & $11 / 10 / 2007$ & $24 / 03 / 2008$ & - \\
$2008-09$ & Maize & $16 / 04 / 2008$ & $02 / 10 / 2008$ & $210-120-120$ \\
& CC/Fallow & $09 / 10 / 2008$ & $11 / 03 / 2009$ & - \\
$2009-10$ & Maize & $03 / 04 / 2009$ & $29 / 09 / 2009$ & $210-120-120$ \\
& CC/Fallow & $05 / 10 / 2009$ & $15 / 03 / 2010$ & - \\
$2010-11$ & Maize & $13 / 04 / 2010$ & $07 / 10 / 2010$ & $210-120-120$ \\
& CC/Fallow & $15 / 10 / 2010$ & $14 / 04 / 2011$ & - \\
$2011-12$ & None & - & - & - \\
& CC/Fallow & $06 / 10 / 2011$ & $30 / 03 / 2012$ & - \\
& Sunflower & $20 / 04 / 2012$ & $12 / 09 / 2012$ & - \\
& CC/Fallow & $05 / 10 / 2012$ & $13 / 03 / 2013$ & $0-30-100$ \\
\hline
\end{tabular}

\subsubsection{Field measurements, sampling and laboratory analysis}

The soil water content was monitored periodically in this study using the Diviner ${ }^{\circledR}$ capacitance probe (Sentek Pty Ltd., Stepney, Australia) that was described in detail by Paltineanu and Starr (1997). Nine access pipes (three repetitions per treatment) were installed in the plots. The probe was introduced once a week to measure the soil water content by centering the sensor at a $10 \mathrm{~cm}$ depth. The average readings were transformed into soil volumetric water content using a calibration equation that was obtained at the experimental site (Gabriel et al., 2010).

Five plants were randomly selected from each plot. The plants were dug carefully ( $\sim 10 \mathrm{~cm}$ each side) and the root system together with the soil were extracted. The first year, samples were taken 95 days after sowing (DAS) sunflower (24/07/2012), with 1267 accumulated degree-days (DD). The accumulated DD was calculated with a base temperature of $8{ }^{\circ} \mathrm{C}$. The second year, samples were taken on two dates, at 54 DAS (11/06/2013; 420 DD accumulated) and at 69 DAS (26/06/2013; 650 DD accumulated) after maize planting. The maize growth stages of the first and second sampling were V5 (5 leaves fully extended) and V7 (7 leaves fully extended), respectively (Ritchie et al., 1992). 
In the laboratory, the roots and the soil from each sample were carefully separated and a composed sample of each part was obtained per plot. The roots were washed with water, cut into $1-2 \mathrm{~cm}$ pieces, cleared with $10 \% \mathrm{KOH}$, acidified with diluted $\mathrm{HCl}$, and stained with a $0.05 \%$ solution of trypan blue in lactoglycerol (Phillips and Hayman, 1970) to estimate root mycorrhizal colonization by the gridline intersect method (Giovannetti and Mosse, 1980). The length of the extraradical mycelium was measured in the soil samples by a combination of methods described by Kabir et al. (1997) and Jakobsen et al. (1992). A soil subsample (2 g) was blended for $30 \mathrm{~s}$ with distilled water. This suspension was then poured through a $250-\mu \mathrm{m}$ sieve and then a $50-\mu \mathrm{m}$ sieve to separate the hyphae. The recovered material was suspended again in water, transferred to a beaker, shaken for $60 \mathrm{~s}$, and left to settle for $10 \mathrm{~min}$. A $20 \mathrm{ml}$ aliquot was stained with trypan blue (12 h) and filtered through a Whatman membrane filter $(0.45 \mu \mathrm{m}$ diameter pores) under vacuum. The hyphae were counted under a microscope, and the hyphae length was calculated according to Tennant (1975). The AM fungal spores were isolated from the soil samples by wet sieving and decanting, followed by sucrose centrifugation (Sieverding, 1991). The number of AMF spores per gram of soil was counted using a microscope.

The glomalin content was estimated by the measurement of the easily extractable glomalin-related soil protein (EE-GRSP), which is considered the most recent deposition fraction (Wright and Upadhyaya, 1998). EE-GRSP was extracted from soil samples with $20 \mathrm{mM}$ sodium citrate at $\mathrm{pH} 7.0$ and $121{ }^{\circ} \mathrm{C}$ for $30 \mathrm{~min}$ (Wright and Upadhyaya, 1998). The protein content of the extracts was quantified using the Bradford protein assay with bovine serum albumin as the standard. The $\beta$-glucosaminidase activity was determined using the method of Parham and Deng (2000) in which subsamples are assayed with $\rho$-nitrophenyl-N-acetyl- $\beta$-Dglucosaminide as substrate and incubated for $1 \mathrm{~h}\left(37^{\circ} \mathrm{C}\right)$. The WSA were determined by wet-sieving of air-dried 1-2 mm aggregates through a $250 \mu \mathrm{m}$ sieve (Kemper and Rosenau, 1986). All of the laboratory analyses were performed in duplicate, and an average was calculated. 


\subsubsection{Statistical analysis}

Statistical analysis was performed using the program Statgraphics Centurion XVI. Each variable was examined using analysis of variance (ANOVA), and the mean comparisons were made using Fisher's Least Significant Difference test at the 0.05 probability level $(\mathrm{P} \leq 0.05)$. ANOVA assumptions of normality and homoscedasticity were checked. Pearson's product-moment between variables and their significance levels were also calculated.

\subsection{RESULTS}

\subsubsection{Soil water content evolution}

In the 2011-12 campaign, the precipitation during the CC/fallow period was $174 \mathrm{~mm}$, whereas in 2012-13, the precipitation was $288 \mathrm{~mm}$. In both periods, the lowest soil water content was found in the barley, and the highest in the fallow treatment, with vetch in between these values (Fig. 2.1). As the CC grew and took up water, the soil water content values diverged. During the periods of the productive crop, soil moisture followed the irrigation cycles and tended to equalize in all of the plots; only occasional differences appeared between treatments. At the time when soil samples were taken for this study, no differences in soil water content between treatments were observed.

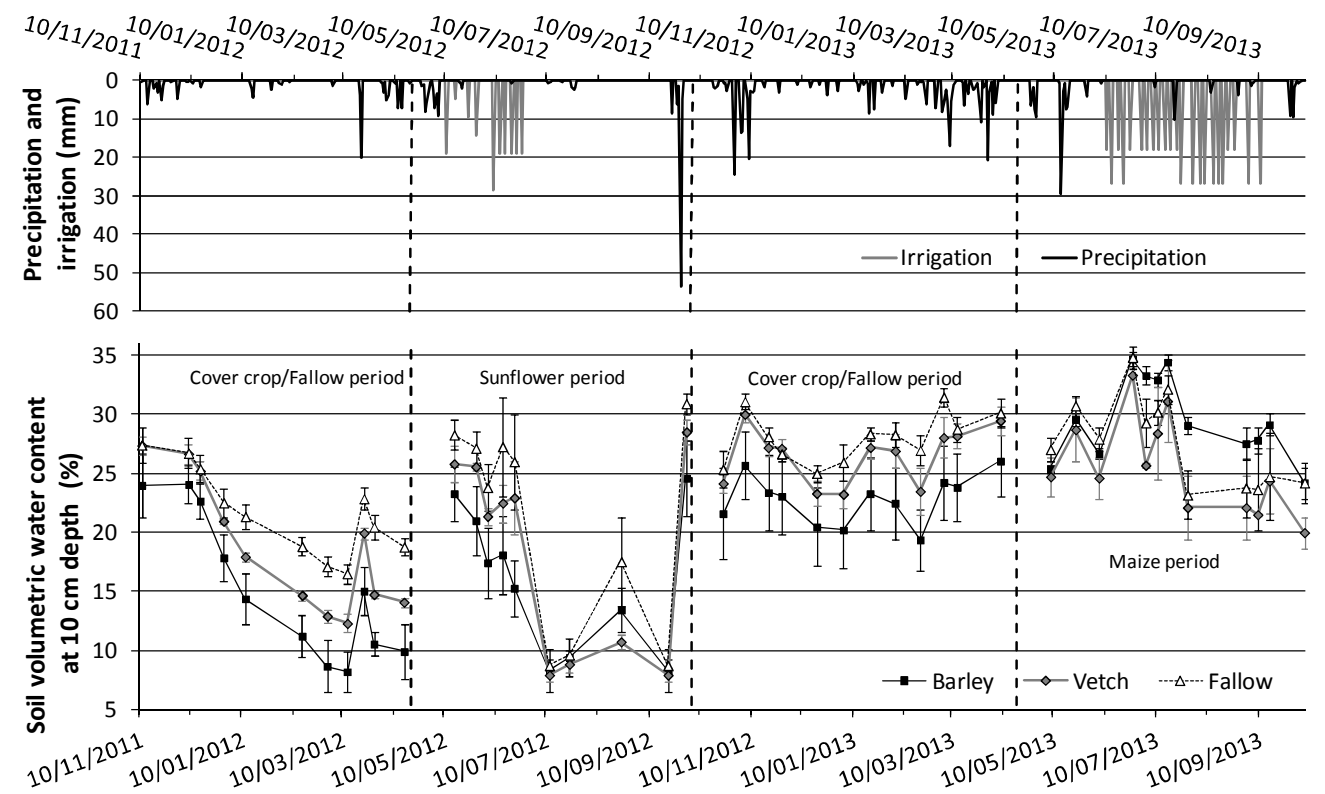

Fig. 2.1. Soil volumetric water content at $10 \mathrm{~cm}$ depth (mean \pm standard error) for the three treatments. 


\subsubsection{Effect of soil cover}

In the sunflower season, no significant difference was observed among treatments in the root colonization percentage (Table 2.2). Nevertheless, the hyphae length and the number of AMF spores were significantly higher in the barley treatment than in the fallow and vetch treatments. Additionally, the EEGRSP content was higher in the barley treatment than in the fallow and vetch treatments. The highest $\beta$-glucosaminidase activity was observed in the barley, followed by the vetch and then the fallow treatment. The WSA was higher for the barley treatment than for the fallow, with the vetch in between. Compared with fallow, barley increased by $80 \%$ the values of hyphae length and $\beta$ glucosaminidase activity, while increments of $30 \%$ were found in the AMF spores, EE-GRSP and WSA. For most variables, vetch performance was more similar to fallow than to barley treatment.

Table 2.2. Effect of the fallow, vetch and barley treatments on the variables directly related to arbuscular mycorrhizal fungi (AMF), the variables indirectly related to AMF (easily extractable glomalin-related soil protein, EE-GRSP, and $\beta$-glucosaminidase activity) and the percentage of water stable aggregates (WSA) at 95 DAS sunflower in 2012 (mean \pm standard error).

\begin{tabular}{|c|c|c|c|}
\hline & Fallow & Vetch & Barley \\
\hline & \multicolumn{3}{|c|}{ Variables directly related to AMF } \\
\hline Root colonization (\%) & $37.56 \pm 3.95 \mathrm{a}$ & $43.50 \pm 5.74 \mathrm{a}$ & $53.55 \pm 5.35 \mathrm{a}$ \\
\hline Hyphae length $\left(\mathrm{cm} \mathrm{g}^{-1}\right)$ & $77.12 \pm 11.37 \mathrm{~b}$ & $82.36 \pm 9.47 \mathrm{~b}$ & $137.16 \pm 19.05 \mathrm{a}$ \\
\hline \multirow[t]{2}{*}{ AMF spores (No. spores g-1) } & $10.9 \pm 0.79 b$ & $11.0 \pm 1.11 \mathrm{~b}$ & $14.5 \pm 0.43 \mathrm{a}$ \\
\hline & \multicolumn{3}{|c|}{ Variables indirectly related to AMF } \\
\hline EE-GRSP (mg g-1) & $0.47 \pm 0.01 b$ & $0.49 \pm 0.041 \mathrm{~b}$ & $0.62 \pm 0.02 \mathrm{a}$ \\
\hline \multirow[t]{2}{*}{$\begin{array}{l}\beta \text { - Glucosaminidase activity } \\
\left(\mathrm{mg} \rho \text {-nitrophenol kg-1 } \mathrm{h}^{-1}\right)\end{array}$} & $13.61 \pm 1.24 \mathrm{c}$ & $18.07 \pm 0.6 \mathrm{~b}$ & $24.69 \pm 0.78 \mathrm{a}$ \\
\hline & \multicolumn{3}{|c|}{$\underline{\text { Soil structure stability }}$} \\
\hline WSA $(\%)$ & $40.10 \pm 2.01 \mathrm{~b}$ & $45.44 \pm 2.54 \mathrm{ab}$ & $51.02 \pm 1.50 \mathrm{a}$ \\
\hline
\end{tabular}

Different letters indicate significant difference among soil cover treatments according to Fisher's LSD at a 0.05 probability level.

In the maize season, on both dates, $\mathrm{CC}$ treatments had higher values of root colonization compared with the fallow treatment (Fig. 2.2). The root colonization increased with the time elapsed from sowing only for the vetch and fallow treatments. The results for the hyphae length and AMF spores were similar to the 
previous year with sunflower, with barley having higher values than the vetch and fallow treatments. The hyphae length increased with time for the three soil cover treatments. The AMF spores were only influenced by time in the barley treatment, decreasing at the second sampling date. The content of EE-GRSP at 54 DAS was higher for the barley treatment than for the vetch and fallow treatments. However, at 69 DAS, both barley and vetch had values that were significantly higher than the fallow treatment. The $\beta$-glucosaminidase activity in the barley and vetch treatments was higher than in the fallow at 54 DAS, but it was only higher in the barley at 69 DAS. The indirect variables were less affected by the sampling date. No
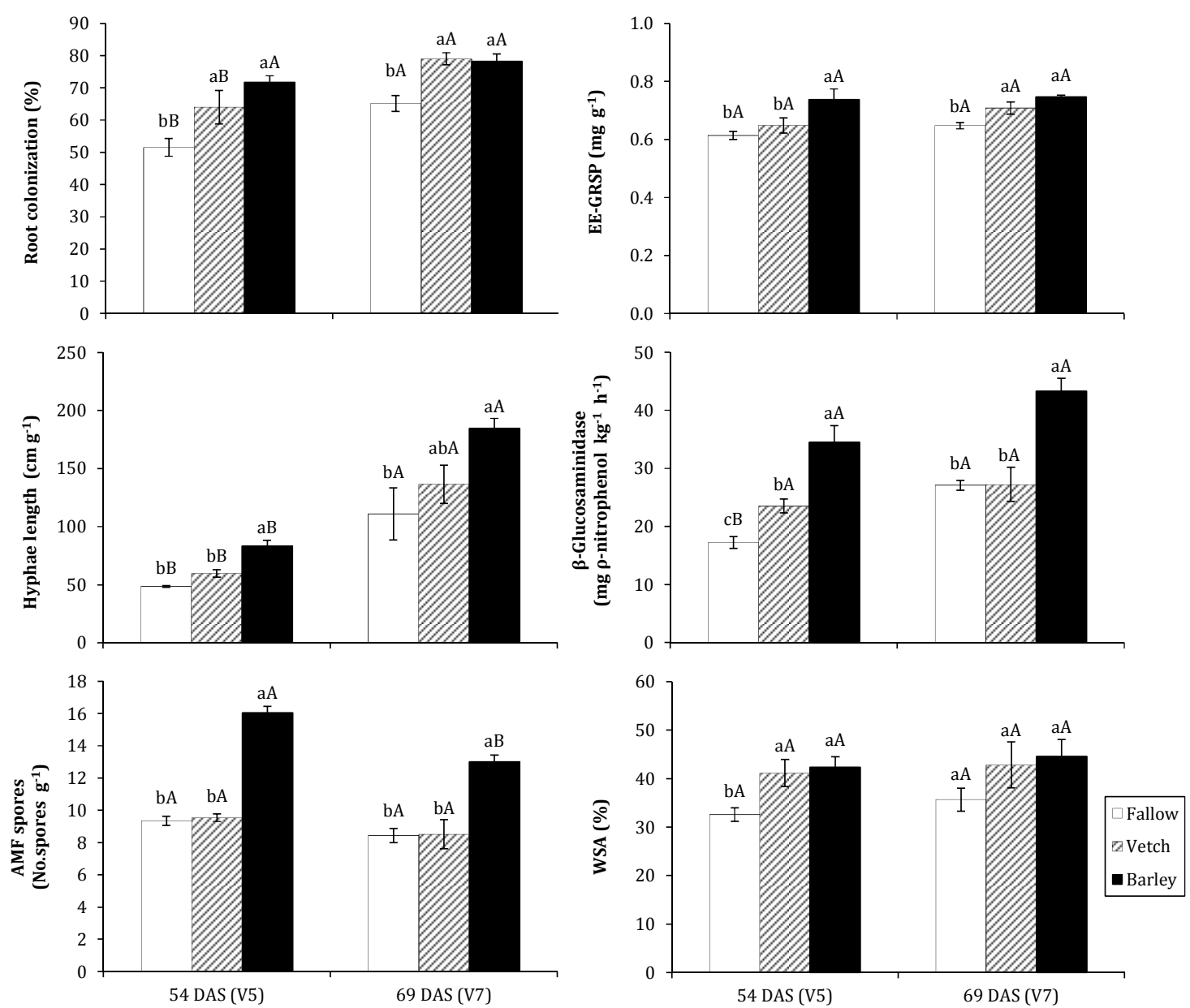

Fig. 2.2. Means of root colonization, length of hyphae, AMF spores, easily extractable glomalin related soil protein (EE-GRSP), $\beta$ - glucosaminidase activity and water stable aggregates (WSA) at 54 and 69 DAS maize in 2013. Different lower case letters indicate significant difference among soil cover treatments according to Fisher's LSD at a 0.05 probability level. Different capital letters indicate significant difference between dates at a 0.05 probability level. Bars are the mean and small bars the standard error. 
significant differences were observed in EE-GRSP between the dates in each treatment, but differences between both CC and the fallow appeared on the second date. The $\beta$-glucosaminidase activity of the fallow treatment was the only indirect variable that increased at 69 DAS compared with the first date, suppressing the difference with the vetch but not with the barley treatment. The WSA showed significant differences among soil cover treatments at 54 DAS, with barley and vetch having the highest values. At 69 DAS, the trend remained but the differences were not significant at $\mathrm{p}<0.05$. The WSA remained steady between dates as expected. The variables of hyphae length, number of spores and $\beta-$ glucosaminidase activity were the most enhanced by CC in terms of percentage. Vetch matched barley only for root colonization and WSA, whereas for the remaining variables, vetch was more similar to fallow.

\subsubsection{Relationships between the fungal and soil variables}

Overall, this study showed positive relationships among the direct variables of AMF, the indirect variables and the WSA in both years of the experiment (Tables 2.3 and 2.4). In the sunflower season, root colonization was positively correlated with the hyphae length and was much weaker $(\mathrm{p}<0.1)$ with the AMF spores (Table 2.3). In addition, the hyphae length and the AMF spores showed a weak $(\mathrm{p}<0.1)$ but positive correlation. The EE-GRSP was positively correlated with AMF spores and showed the same tendency with the other two variables directly related to AMF. The $\beta$-glucosaminidase activity was also positively related to the hyphae length, AMF spores and EE-GRSP. The WSA was highly correlated with the hyphae length and $\beta$-glucosaminidase activity. 
Table 2.3. Correlation coefficients and significance levels among the direct variables (root colonization, hyphae length, AMF spores), the indirect variables (easily extractable glomalin-related soil protein, EE-GRSP, and $\beta$-glucosaminidase activity) and the percentage of water stable aggregates (WSA) at 95 DAS sunflower in 2012.

\begin{tabular}{cccccc}
\hline & $\begin{array}{c}\text { Root } \\
\text { colonization }\end{array}$ & $\begin{array}{c}\text { Hyphae } \\
\text { length }\end{array}$ & $\begin{array}{c}\text { AMF } \\
\text { spores }\end{array}$ & EE-GRSP & $\beta$-Glucosaminidase \\
\hline Hyphae length & $0.66^{*}$ & & & & \\
AMF spores & $0.60^{+}$ & $0.60^{+}$ & & & \\
EE-GRSP & $0.57^{+}$ & $0.55^{+}$ & $0.65^{*}$ & & \\
$\beta$-Glucosaminidase & 0.44 & $0.71^{*}$ & $0.66^{*}$ & $0.73^{*}$ & \\
WSA & 0.54 & $0.80^{* *}$ & 0.48 & 0.44 & $0.84^{* *}$ \\
\hline
\end{tabular}

$+, * * *, * * *$, significant at $P<0.1,0.05,0.01$ and 0.001 , respectively.

In the maize season, the correlations were similar to the previous year (Table 2.4). A relationship was observed between root colonization and the hyphae length. The content of EE-GRSP and the $\beta$-glucosaminidase activity were significantly related to each other and with all of the variables directly related to AMF, the root colonization, the hyphae length and the AMF spores. The WSA was correlated with the root colonization, EE-GRSP and $\beta$-glucosaminidase activity. It is noteworthy that the relationship with the hyphae length vanished. On both sampling dates in the sunflower and maize seasons, the linear correlation between the EE-GRSP and the root colonization became stronger ( $r=0.79 * * *)$ (Fig. 2.3).

Table 2.4. Correlation coefficients and significance levels among the direct variables (root colonization, hyphae length, AMF spores), the indirect variables (easily extractable glomalin-related soil protein, EE-GRSP, and $\beta$-glucosaminidase activity) and the percentage of water stable aggregates (WSA) for the two sampling dates during maize cultivation in 2013.

\begin{tabular}{cccccc}
\hline & $\begin{array}{c}\text { Root } \\
\text { colonization }\end{array}$ & $\begin{array}{c}\text { Hyphae } \\
\text { length }\end{array}$ & $\begin{array}{c}\text { AMF } \\
\text { spores }\end{array}$ & EE-GRSP & $\beta$-Glucosaminidase \\
\hline Hyphae length & $0.77^{* * *}$ & & & & \\
AMF spores & 0.27 & 0.19 & & & \\
EE-GRSP & $0.56^{* *}$ & $0.57^{* *}$ & $0.50^{*}$ & & \\
$\beta$-Glucosaminidase & $0.68^{* * *}$ & $0.74^{* * *}$ & $0.56^{* *}$ & $0.73^{* * *}$ & \\
WSA & $0.57^{* *}$ & $0.38^{+}$ & 0.20 & $0.56^{* *}$ & $0.62^{* *}$ \\
\hline
\end{tabular}

,$+ * * * * * *$, significant at $P<0.1,0.05,0.01$ and 0.001 , respectively. 


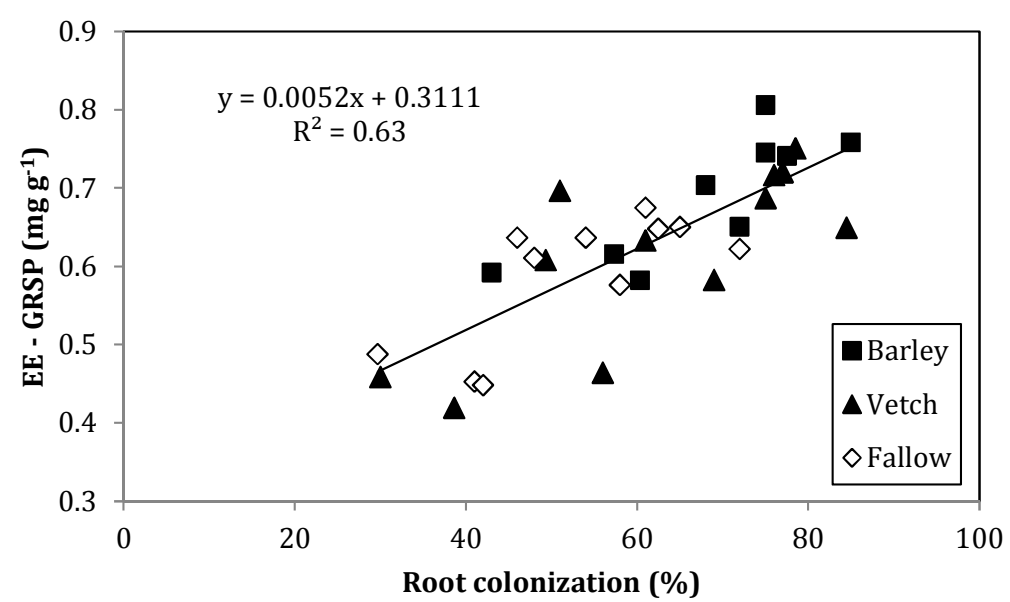

Fig. 2.3. Linear relationship between root colonization and easily extractable glomalin-related soil protein (EE-GRSP) for all dates in both years in the barley, vetch and fallow treatments.

\subsection{DISCUSSION}

In general, these results showed that replacing the winter fallow by a CC enhanced AMF in the subsequent main crop, either sunflower or maize. This result is consistent with other studies that highlighted the importance of the existence of a host for AMF during the intercrop period (Galvez et al., 1995; Kabir and Koide, 2002). The host plant supplies accommodations and carbohydrates for the formation, maintenance and function of mycorrhizal structures (Wright et al., 1998). Cover crops also modify some environmental conditions, such as soil water content at planting (Dabney et al., 2001), which is a major factor in the maintenance of AMF inoculum (Ruiz-Lozano and Azcon, 1996). In our study, the lowest soil water content associated with the barley treatment is in agreement with Gabriel et al. (2012), and it is related to a higher water consumption derived by the higher biomass of this CC (average $3.3 \mathrm{Mg} /$ ha from 7 campaigns) compared with vetch (average $1.9 \mathrm{Mg} /$ ha from 7 campaigns) and fallow (no biomass). However, the lower water content in barley did not negatively affect mycorrhizal activity because in this cover we found the highest values of AMF parameters. The great root system from barley (Ramirez-Garcia et al., 2014), while offering a host for $\mathrm{AMF}$, seems to compensate for the possible negative effect of the reduced water availability, even under the drier conditions of the 2011/12 season. Buyer et al. (2010) also found that the CC influence was more relevant than soil moisture or 
soil temperature in controlling AMF and other microbial biomass. Thus, in this study, the importance of CC as a host plant prevailed over the soil moisture reduction in the survival of the AMF inoculum. Therefore, the benefits of CC on AMF were maintained under the semiarid conditions of the Mediterranean climate.

The positive effects of $\mathrm{CC}$ on direct AMF variables found in our study are in general agreement with other studies in the Mediterranean and other climatic areas. Most studies agreed that a variety of CC enhances root colonization in the subsequent maize crop (Boswell et al., 1998; Deguchi et al., 2007; Kabir and Koide, 2000, 2002; White and Weil, 2010), even under Mediterranean climate conditions (Njeru et al., 2014). Studies involving other main crops are scarce, but the effect of CC was similar, e.g., in leeks (Sorensen et al., 2005). In general, the percentages of increase relative to fallow in this study were moderate compared with other studies in which increments of 3-4-fold were found (Boswell et al., 1998; Kabir and Koide, 2002) or even 12-fold (Deguchi et al., 2007), probably because we found large values for root colonization even under fallow conditions. These large values may be related to the optimal temperature and soil moisture conditions from the beginning of maize growth. In the case of sunflower, the root colonization tended to be higher under CC but differences were not significant at $\mathrm{p}<0.05$, probably because of the late sampling date (95 DAS) and the favorable environmental conditions. The high temperatures in summer and the irrigation system may have anticipated the equilibrium between $\mathrm{CC}$ and fallow conditions, erasing previous differences among treatments. In addition, as the sunflower continues to develop after sowing, the AMF and the remaining microbial community structure would have become more strongly influenced by the growing crop (Wortman et al., 2013). It would have been interesting to study different sampling dates during sunflower development, considering that the differences could appear in earlier stages.

In relation to the hyphae length, our results corroborated previous studies. The density of mycorrhizal hyphae under rye or oats cover treatments was twice that of fallow conditions (Kabir and Koide, 2002). In addition, Lehman et al. (2012) found that CC significantly increased the mycorrhizal inoculum potential measured 
using the most-probable-number, with forage oats being the most effective. The effect of CC on AMF spores has been less studied, and the results are not homogenous. We found that barley increased the number of spores by $42-72 \%$, but vetch was similar to fallow. This result differs from Galvez et al. (1995), who found that vetch had more spores number relative to fallow and from Boswell et al. (1998), who did not report differences between CC and fallow. The heterogeneity in the results may be due to the methodology. The process of spore count under a microscope may include nonviable spores, either because they are parasitized, old, broken or thick-walled (Walley and Germida, 1995), which may give rise to an overcount. In addition there are AMF spores too small to be reliable extracted by wet sieving, so this method would generate a measurement error that should be taken into consideration. Furthermore, differences in spore number may be due to the variety in the sampling dates among studies, environmental conditions during the experiment or crop dependence on mycorrhizal which influence on the sporulation and spore germination (Declerck et al., 2001; Plenchette et al., 1983). Finally, we remark the different pattern for barley and vetch in both sunflower and maize crops in which the benefits to barley on AMF were larger compared to vetch. Higo et al. (2015) compared in a pot experiment the performance of four potential CC (two legumes and two grasses) and found higher values of AMF colonization in the roots of barley compared with hairy vetch. They attributed these differences to host selectivity. The higher root colonization in barley during the $\mathrm{CC}$ season along with its greater root biomass may have enhanced propagule generation (Higo et al., 2013), favoring a greater infection in the subsequent crop.

Cover crops also enhanced the AMF indirect variables, in agreement with other studies. Wright and Anderson (2000) and Wright et al. (1999) in the USA, and Balota et al. (2014b) in Brazil reported an increase in GRSP content associated with CC. In these studies, rotations with fallow or with CC were compared, and they observed that the GRSP content increased in the CC. The results obtained for $\beta$-glucosaminidase activity are in agreement with the studies of Acosta-Martínez et al. (2011) and Ekenler and Tabatabai (2003) in the USA. They found that CC enhanced $\beta$-glucosaminidase activity and other enzymatic activities, which was attributed to increased biomass in the soil and/or the rhizosphere effect during 
winter. The order of barley $>$ vetch $>$ fallow for this enzyme activity in our study seems to follow the same order of the soil carbon content: barley $(1.5 \%) \geq$ vetch $(1.4 \%)>$ fallow (1.2\%) (data from October 2012, not published). This result suggests a positive correlation between this enzymatic activity and the organic carbon content as previously reported by Ekenler and Tabatabai (2003).

We found contradictory results with regard to the influence of sampling date on the effect of CC. In the case of root colonization in maize, our results differ from other studies reporting that the differences between $\mathrm{CC}$ and fallow are found in the early sampling of the subsequent crop but tend to disappear with DAS (Deguchi et al., 2007; Sorensen et al., 2005; White and Weil, 2010). In contrast, this study showed significant differences (CC> fallow) until 69 DAS maize (V7) in both CC. These results agree with Kabir and Koide (2002), who found that the positive effect of CC on root colonization lasted until 68 DAS. Also in the case of the length of hyphae, the differences between barley and fallow remained significant until 69 DAS maize in contrast to the study of Kabir and Koide (2002), in which differences remained only until 27 DAS sweet corn. The AMF spore density is another parameter that has varied significantly between the two sampling dates for maize but only in the barley treatment. The decrease in the AMF spores may be due to spore germination enhanced by suitable moisture, temperature and $\mathrm{pH}$ conditions in the soil (Azcón-Aguilar and Barea, 1995). The different soils and environmental conditions among studies may generate these variations in results, in addition to the different covers or main crops used.

The relationship between the variables directly related to AMF and the GRSP content is a controversial topic. Most studies did not find correlations between AMF variables and glomalin (Lovelock et al., 2004b; Lutgen et al., 2003; Rillig, 2004; Rillig et al., 2001a). In general, the lack of correlation is attributed to the different turnover between the AMF and the glomalin content. This was why we selected the glomalin fraction of more recent deposition in this study; i.e., the EEGRSP. We found positive correlations between this glomalin fraction and the three AMF variables in maize and to a lesser extent in sunflower. Our results are in line with Bedini et al. (2013), who detected a strong correlation of GRSP with soil 
mycorrhizal inoculum potential determined in a bioassay, a moderate correlation with root colonization and no correlation with spore number. On the other hand, and in agreement with our results, a correlation between EE-GRSP and AMF spore density was found by Bedini et al. (2007) and Bai et al. (2009). The fact that spores constitute the most persistent component of fungal structures (Wright and Upadhyaya, 1998) and that the majority of glomalin is contained in hyphae and spores (Driver et al., 2005) could explain these positive correlations. According to our results, EE-GRSP could be considered as a biochemical indicator of AMF, with the advantage of being an easy, quick and inexpensive laboratory determination. In addition to EE-GRSP, $\beta$-glucosaminidase activity also showed positive correlations with the three studied AMF variables and with EE-GRSP in both sunflower and maize crops. This result is partially in line with the results obtained by Miller et al. (1998), Parham and Deng (2000) and Acosta-Martinez et al. (2004), who showed a relationship of $\beta$-glucosaminidase activity with soil fungal biomass. Our results suggest that this enzyme could be an easy fungi biomarker, but due to its weaker relationship with AMF, additional investigations are required to confirm that the $\beta$ glucosaminidase activity could be used as an AMF indicator.

In this study, we also included the WSA as a soil quality indicator. The replacement of fallow by $\mathrm{CC}$ has a positive effect on soil aggregation, as reported in several studies. For example, winter wheat and dandelion used as CC promoted WSA compared with fallow (Kabir and Koide, 2000). Villamil et al. (2006) also found the same effect with rye and vetch. In a semi-arid region in Spain, Muñoz et al. (2007) showed an increase in soil aggregate stability by using oats as a CC. In our study, barley and vetch increased WSA at 54 DAS maize; the differences disappeared at 69 DAS, although the trend remained. This lack of difference may be related to the higher soil moisture at sampling (Lammerding et al., 2011) due to irrigation. The enhancement of soil aggregation derived by CC introduction is normally attributed to the input of fresh plant residues in the soil, mainly particulate organic matter (Six et al., 2000), which is higher in vetch and barley. Soil aggregation is promoted by other biological factors, such as fungi and other soil microorganisms (Six et al., 2004). The fungal mycelium acts as a "sticky string bag" favoring the entangling and enmeshment of soil particles within the hyphae 
network to form macroaggregates (Miller and Jastrow, 2000). In addition, the glomalin produced by AMF seems to act as hydrophobic glue, improving water stability aggregation (Wright and Upadhyaya, 1998). In our case, the higher values of both extra-radical mycelium and glomalin content under CC treatments may have contributed to improved soil aggregation. The positive correlations of WSA with the hyphae length in the case of sunflower $\left(r=0.80^{* *}\right)$ and with EE-GRSP $\left(\mathrm{r}=0.56^{* *}\right)$ in maize seem to confirm that the replacement of fallow by CC enhances soil aggregate stability, therefore improving soil quality via AMF promotion.

\subsection{CONCLUSIONS}

The introduction of CC to replace the fallow periods enhanced AMF development in the subsequent sunflower and maize crops. It improved the variables directly related to AMF (mycorrhizal colonization, extra-radical mycelium and AMF spores) and some indirectly related variables (EE-GRSP and $\beta$ glucosaminidase activity), as well as the water stable aggregates. Therefore, the benefits of $\mathrm{CC}$ on AMF were maintained under the semiarid conditions of the Mediterranean climate. In general, the use of barley as CC had a positive effect on all of the AMF variables compared to fallow, whereas the vetch treatment was intermediate. Thus, from the AMF promotion perspective, we recommend the use of a grass such as barley when replacing fallow by CC.

Positive relationships were found between the variables directly related to AMF, EE-GRSP and $\beta$-glucosaminidase activity. These results suggest the possibility of using the determination of indirectly related variables, mainly the EE-GRSP, to rapidly, easily and economically estimate the AMF abundance. Further work is required to confirm this potential. 



\section{Chapter 3}

\section{Mycorrhizal activity, soil quality and plant parameters affected by winter cover crops ${ }^{1}$}

1 García-González, I., Quemada, M., Gabriel, J.L., Alonso-Ayuso, M., Hontoria, C. Mycorrhizal activity, soil quality and plant parameters affected by winter cover crops. Submitted for publication to Plant and Soil. 



\subsection{INTRODUCTION}

Winter cover cropping is an important practice in sustainable agriculture and is receiving increasing attention in Mediterranean areas (Gabriel et al., 2016; Tosti et al., 2014). The use of cover crops (CC) provides numerous advantages for the soil, but they do not always benefit the main crop yield in semiarid conditions, most likely due to increased pre-emptive competition for nutrients and water with the main crop (Gabriel et al., 2013; Lascano et al., 2015; Salmerón et al., 2010). Cover crops offer protection for the soil against water and wind erosion and also improve soil quality. Properties such as organic matter content, soil aggregation and aeration are enhanced with the establishment of CC (Reeves, 1994). In addition, they stimulate microbiological activity in the soil and may improve the development and activity of microorganisms, such as arbuscular mycorrhizal fungi (AMF) (Kabir, 2005). The symbiosis between fungus and plant roots provides a supply of organic carbon for the AMF, which in turn enhances plant nutrient uptake, particularly $\mathrm{P}$, and improves its tolerance to pathogens and stress conditions, such as drought, adverse temperature, salinity and toxic metals (Smith and Read, 2008).

Arbuscular mycorrhizal fungi are obligate symbionts and their association with roots is essential for their development. A long period with no host plants, therefore, may decrease the inoculum potential and the colonization in the subsequent crop (Galvez et al., 1995). Studies (mostly in maize) have shown that replacing fallow by $\mathrm{CC}$ increases AMF activity in the following crop. For example, mycorrhizal colonization was stimulated in the subsequent maize crop using grasses such as rye, oats or barley as winter CC (García-González et al., 2016b; Kabir and Koide, 2002; White and Weil, 2010) or legumes such as vetch and black medic (Njeru et al., 2014; Sorensen et al., 2005). However, differences in AMF activity due to CC are sometimes dependent on the sampling dates and not all of the indicators used to evaluate AMF abundance are equally sensitive to time. For instance, Sorensen et al. (2005) and Deguchi et al. (2007) observed differences in mycorrhizal colonization in the early stages of growth of the main crop, but these disappeared over time. On the other hand, studies by Kabir and Koide (2002) and 
García-González et al. (2016b) found differences in a variety of AMF parameters that persisted until the ninth week after planting the main crop. Therefore, the influence of the sampling date should be considered together with the effect of the $\mathrm{CC}$ on $\mathrm{AMF}$.

Arbuscular mycorrhizal fungi enhance soil quality as a result of their stabilizing effect on soil structure (Miller and Jastrow, 2000; Rillig et al., 2002). The external mycelium contributes to the entangling and enmeshment of soil particles within the hyphae network, favoring the formation of macroaggregates (Miller and Jastrow, 2000). In addition, AMF produce glomalin, which is a glycoprotein located in the hyphae and spore walls that acts as a glue, improving aggregate stability (Bedini et al., 2009; Peng et al., 2013; Wright and Upadhyaya, 1998). The easilyextracted glomalin fraction has been proposed as an indicator of AMF abundance (García-González et al., 2016b). Both AMF mycelium and glomalin, therefore, can be used to evaluate the influence of CC on AMF activity and the corresponding effect on soil aggregate stability.

Arbuscular mycorrhizal fungi stimulation as a result of replacing fallow by CC may also influence the nutritional state of the subsequent crop and, correspondingly, the yield. The presence of AMF extra-radical mycelium that acts as an extension of the host plant root system plays an important role in the obtention of soil nutrients, thus increasing the capabilities of plants to acquire nutrients. Various studies have reported relationships between AMF presence after CC and plant nutrient content, especially, when focusing on the P cycle (Kabir and Koide, 2002; Njeru et al., 2014). For example, field experiments with CC, such as that of Kabir and Koide (2002) have found a positive relationship between the shoot $\mathrm{P}$ concentration and the maize yield and reproductive maturity, measured as the percentage of tasseling.

The influence of CC on nutritional aspects via AMF may interact with the effect provided by the use of CC as green manure. Cover cropping allows for the return of organic material to the soil, maintaining a nutrient rich seedbed for the subsequent crop. Soil microorganisms and enzymes, many of which interact with $\mathrm{AMF}$, are involved in key nutrient cycles such as those of $\mathrm{C}, \mathrm{N}$ and $\mathrm{P}$. For instance, 
the activity of the $\beta$-glucosaminidase enzyme is responsible for degrading the chitin that will influence both the $\mathrm{C}$ and $\mathrm{N}$ soil cycles (Geisseler and Horwath, 2009). This enzyme was proposed as a semi-quantitative indicator of soil fungal biomass (Miller et al., 1998) because of its relationship with ergosterol (Andersson et al., 2004) and other parameters related to AMF (García-González et al., 2016b). Phosphatase is one of the enzymes that permits the mineralization of organic $\mathrm{P}$ into plant-available forms. The extracellular alkaline phosphatase is produced by microbes (Spohn and Kuzyakov, 2013) and its activity seems to be affected by the presence of AMF (Marschner and Baumann, 2003). Despite these interactions, few studies have focused simultaneously on CC, plant nutrients, enzyme activities and their relationships with AMF parameters.

The variety of results found in studies with different climates and mycorrhizal activities during crop development highlight the need to study in depth how AMF activity is affected by CC. Most studies have been carried out in temperate areas and short-term field experiments, but CC grown under semiarid Mediterranean climate have specific characteristics that should be clarified. In addition, long-term experiments allow the microbial community to stabilize and show the cumulative effect of treatments. It is also important to study the relationships between AMF parameters with soil enzymes and maize plant nutrients to better understand the AMF-soil-plant interactions. The main objective of this experiment was to study the legacy of CC on AMF activity and look at the relationship of this influence with a number of soil and plant parameters during the subsequent maize crop. We hypothesized that i) the replacement of fallow by CC would increase the mycorrhizal activity and that this increment would be time dependent; ii) CC and their stimulation effect on AMF would improve soil aggregation and nutrient parameters and, iii) as a result, the yield of the subsequent maize crop would be increased. To test these hypotheses, we studied the effect of CC on selected plant and soil parameters in the eight year of a field experiment with maize as main crop. 


\subsection{MATERIALS AND METHODS}

\subsubsection{Study site and experimental design}

The study was conducted at the site of a long-term experiment established in 2006. It was located at La Chimenea Field Station $\left(40^{\circ} 03^{\prime} \mathrm{N}, 03^{\circ} 31^{\prime} \mathrm{W}, 550 \mathrm{~m}\right.$ a.s.l.) in the central Tajo river basin near Aranjuez (Madrid, Spain). The soil is a clay loam with $260 \mathrm{~g} \mathrm{~kg}^{-1}$ sand (2000-50 $\left.\mu \mathrm{m}\right), 490 \mathrm{~g} \mathrm{~kg}^{-1}$ silt (50-2 $\left.\mu \mathrm{m}\right)$ and $250 \mathrm{~g}$ $\mathrm{kg}^{-1}$ clay $(<2 \mu \mathrm{m})$, classified as Typic Calcixerept (Soil Survey Staff, 2014). At the time of the survey, the mean values of top soil $(0-20 \mathrm{~cm})$ properties were the following: $\mathrm{pH}_{\text {water }}(1: 2.5), 7.8$; organic matter, $19 \mathrm{~g} \mathrm{~kg}^{-1}$; and calcium carbonate, 165 $\mathrm{g} \mathrm{kg}^{-1}$. The climate of this area is Mediterranean semiarid (Köppen, 1900). Mean annual temperature is $14.2^{\circ} \mathrm{C}$ and mean annual precipitation is $350 \mathrm{~mm}$.

This long-term experiment was divided into twelve plots $\left(12 \times 12 \mathrm{~m}^{2}\right)$, randomly distributed in four replicates of three treatments. In 2013, two cover crops, barley (Hordeum vulgare L., cv. Vanessa) and vetch (Vicia sativa L., cv. Aitana) were planted in mid-October during the fall-winter period, with fallow (no cover) as the control. In 2014, all plots were treated with one application of glyphosate 2\% (N-phosphonomethyl glycine) to terminate the CC (14/3/2014). Maize (Zea mays L., G-98 Pioneer) was sown in early spring over the chopped CC residue by direct sowing (7/4/2014). The maize was harvested in early autumn, and the residues were removed from the plots (20/9/2014). A sprinkler irrigation system (12 x $\left.12 \mathrm{~m}^{2}, 9.5 \mathrm{~mm} \mathrm{~h}^{-1}\right)$ was used to water the crop, according to crop evapotranspiration (ETc) requirements, calculated by the FAO method (Allen et al., 1998). Fertilization was adjusted according to crop requirement, $\mathrm{N}$ content in CC residues and soil mineral $\mathrm{N}$. The application rates were: $170 \mathrm{~kg} \mathrm{~N} \mathrm{ha-1}^{-1}$ as ammonium nitrate to fallow, $140 \mathrm{~kg} \mathrm{~N} \mathrm{ha}^{-1}$ to vetch and $190 \mathrm{~kg} \mathrm{~N} \mathrm{ha}^{-1}$ to barley, when the maize had eight leaves (56 days after sowing). All plots received $30 \mathrm{~kg} P$ $\mathrm{ha}^{-1}$ as triple superphosphate and $100 \mathrm{~kg} \mathrm{~K} \mathrm{ha}^{-1}$ as potassium sulfate at the time of sowing. In the three previous years (2011 to 2013) no mineral fertilizers were applied, except for $30 \mathrm{~kg} \mathrm{P} \mathrm{ha}^{-1}$ and $100 \mathrm{~kg} \mathrm{~K} \mathrm{ha}^{-1}$ in 2013. Detailed information on the long-term experiment can be found in García-González et al. (2016b). 


\subsubsection{Analysis of maize roots and soil}

Five maize plants were randomly selected from each plot on four dates during the growing season. The root system and soil around the roots were collected by digging carefully ( $\sim 10 \mathrm{~cm}$ each side). The first sampling date was 21 days after sowing (DAS) the maize (28/04/2014), with 170 accumulated degreedays (DD). The accumulated DD was calculated using a base temperature of $8{ }^{\circ} \mathrm{C}$. The subsequent sampling dates were at 36 DAS (13/05/2014; 340 accumulated DD), 52 DAS (29/05/2014; 490 accumulated DD) and 67 DAS (13/06/2014; 679 accumulated DD). The corresponding maize growth stages, according to the $\mathrm{BBCH}$ scale (Lancashire et al., 1991), were 12 (2 leaves fully extended), 13 (3 leaves fully extended), 17 (7 leaves fully extended) and 19 (10 leaves fully extended), respectively.

The fine roots were rinsed, cleared with $10 \% \mathrm{KOH}$ and stained with trypan blue (Phillips and Hayman, 1970) to obtain the percentage of mycorrhizal colonization by the grid-line intersect method (McGonigle et al., 1990). The length of the extraradical mycelium was obtained from a soil subsample that was sieved and stained, following the process described by García-González et al. (2016b). Spores of AMF were extracted from the soil using the wet sieving method followed by a sucrose gradient centrifugation (Sieverding, 1991). In a Petri dish, the number of AMF spores was counted per gram of soil with the aid of a microscope. The easily extractable glomalin-related soil protein (EE-GRSP) is the fraction of glomalin selected for this study because it refers primarily to the recently produced glomalin deposited in the soil. The EE-GRSP was determined by the method of Wright and Upadhyaya (1998) from soil samples with $20 \mathrm{mM}$ sodium citrate at pH 7.0 and $121{ }^{\circ} \mathrm{C}$ for $30 \mathrm{~min}$ and then quantified using the Bradford protein assay. Despite that other organic matter substances together with EE-GRSP are extracted by this procedure (Purin and Rillig, 2007), there are studies that proposed EE-GRSP as an indicator of AMF abundance due to the fast and easy quantification and strong correlation with AMF propagules (Bedini et al., 2013; García-González et al., 2016b; Peng et al., 2013). 
The water stable aggregates (WSA) were determined by wet-sieving of airdried 1-2 mm aggregates through a $250 \mu \mathrm{m}$ sieve (Kemper and Rosenau, 1986). Available phosphorus in the soil was extracted with $0.5 \mathrm{M} \mathrm{NaHCO}_{3}$ adjusted to $\mathrm{pH}$ 8.5 (Olsen, 1954) and determined colorimetrically (Murphy and Riley, 1962). The $\beta$-glucosaminidase activity was obtained by the method of Parham and Deng (2000), incubating soil subsamples with $\rho$-nitrophenyl-N-acetyl- $\beta$-Dglucosaminide as the substrate for $1 \mathrm{~h}$ at $37^{\circ} \mathrm{C}$. In this study we also evaluated the activity of the enzyme alkaline phosphatase, which is secreted by microbes and is prevalent in alkaline soils (Spohn and Kuzyakov, 2013), since the pH of its determination is close to the soil $\mathrm{pH}$ in our study. This enzyme activity was measured at $\mathrm{pH} 8.5$ using $\rho$-nitrophenyl phosphate as the substrate and incubating the samples for $1 \mathrm{~h}$ at $37^{\circ} \mathrm{C}$ (Tabatabai and Bremner, 1969).

All the values presented are the mean of duplicate measurements. Mycorrhizal parameters and WSA were measured for all four sampling dates, whilst enzymatic activities and soil P content were analyzed for the first three dates only.

\subsubsection{Maize plant measurements and analysis}

Maize shoots taken on the first three sampling dates were oven dried at $65^{\circ} \mathrm{C}$ for $72 \mathrm{~h}$ and ground in a ball mill. Subsamples were digested with $\mathrm{H}_{2} \mathrm{O}_{2}$ and $\mathrm{HNO}_{3}$ to determine the $\mathrm{P}$ concentration colorimetrically (Watanabe and Olsen, 1965). The total $\mathrm{C}$ and $\mathrm{N}$ shoot concentrations were analyzed using the Dumas combustion method (TruMac CN, Leco Instruments, St. Joseph, USA).

The heights of thirty maize plants, selected at random from each plot, were recorded every week from the beginning of the maturity period (at 79, 87 and 95 DAS). At crop harvest, the maize biomass was determined by sampling one lineal meter from a row in each plot (20/09/2014). The grain was removed from the cobs, dried at $65{ }^{\circ} \mathrm{C}$ and analyzed to obtain the $\mathrm{N}$ content using the Dumas combustion method (TruMac CN, Leco Instruments, St. Joseph, USA) and the P content by Watanabe and Olsen (1965). 


\subsubsection{Statistical analyses}

Statistical analyses were performed using the Statgraphics Centurion XVI software. We analyzed AMF parameters (mycorrhizal colonization, length hyphae, AMF spores and EE-GRSP), WSA related to soil quality and, in addition, nutritional parameters that aid the evaluation of the effect of AMF in the soil and maize. Each variable was examined using analyses of variance (ANOVA) and Fisher's Least Significant Difference test was used to compare the means. All variables met the criteria of normality and homoscedasticity. The Pearson's product-moment and their significance levels were also calculated to analyze the correlation between variables.

\subsection{RESULTS}

All the AMF parameters studied, i.e. mycorrhizal colonization, length of hyphae, spore abundance and EE-GRSP content had the highest values in maize after barley, whereas maize after fallow frequently had the lowest values (Fig. 3.1). The increments from barley to fallow for the four parameters were 7\%, 39-124\%, $48-87 \%$ and $9-32 \%$, respectively. In contrast to our expectations, the vetch treatment did not benefit AMF parameters and tended to behave similarly to fallow. Arbuscular mycorrhizal fungi parameters were affected by CC for most sampling dates except for mycorrhizal colonization, which was only affected at the early stage (21 DAS). With regards to the WSA (Fig. 3.2), the CC treatments tended to stimulate the soil aggregate stability, with respect to fallow, but means were only different at 21 DAS (51\% increase for barley) and at 67 DAS (25\% increase for both CC). All AMF parameters except mycorrhizal colonization had positive and strong relationships with each other and with WSA at 21 DAS (Table 3.1). Mycorrhizal colonization, on the other hand, only had a very weak or no correlation with the other variables. 

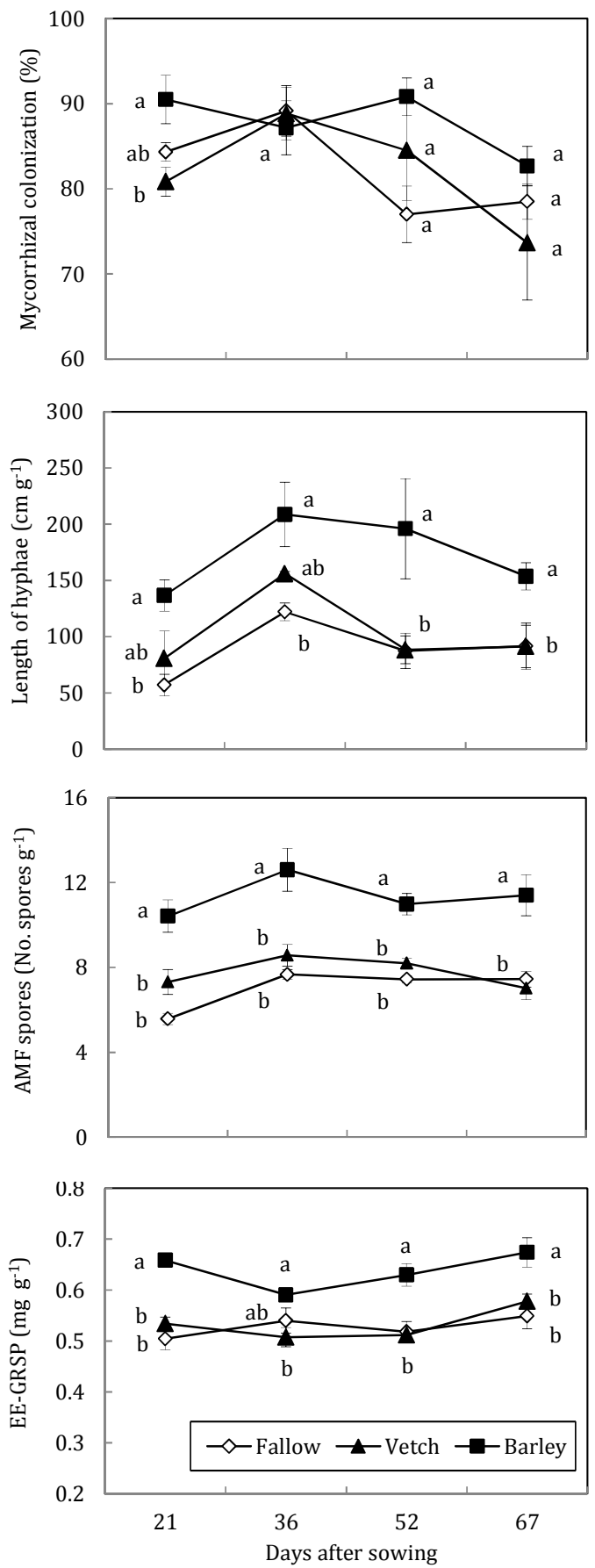

Fig. 3.1. Arbuscular mycorrhizal fungi (AMF) parameters: mycorrhizal colonization, length of hyphae, arbuscular mycorrhizal spores and easily extractable glomalin-related soil protein (EEGRSP) for the four sampling dates. Different letters for a given date indicate significant difference between treatments at $P<0.05$, according to Fisher's LSD test. Bars indicate SE. 


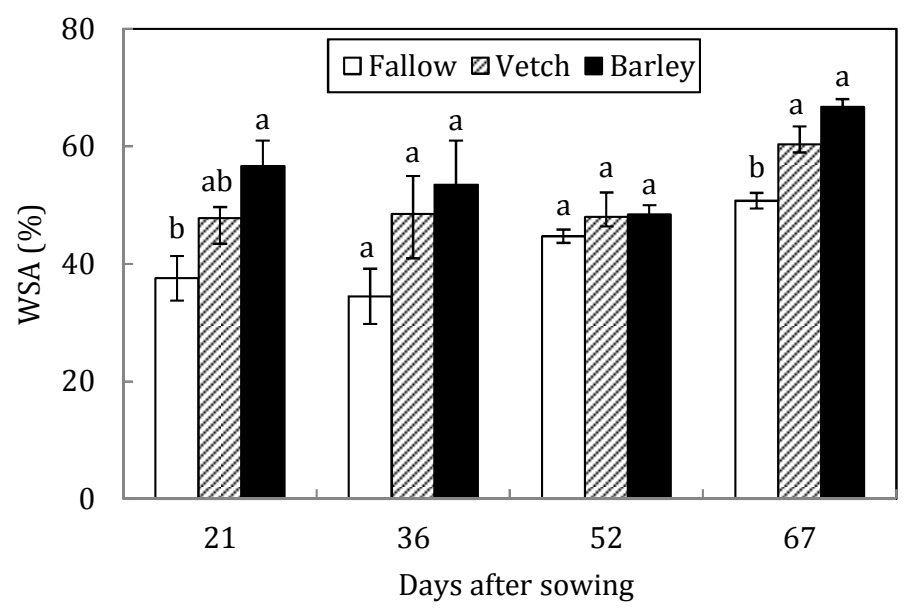

Fig. 3.2. Mean water stable aggregates (WSA) at $21,36,52$ and 67 days after sowing maize. Bars with different letters for a given date indicate significant difference between treatments at $P<0.05$, according to Fisher's LSD test. Error bars indicate SE.

Table 3.1. Pearson correlation (r) between the arbuscular mycorrhizal fungi (AMF) parameters: mycorrhizal colonization, hyphae length, AMF spores and easily extractable glomalin-related soil protein (EE-GRSP) and the percentage of water stable aggregates (WSA) at 21 days after sowing in the fallow, vetch and barley treatments.

\begin{tabular}{ccccc}
\hline & $\begin{array}{c}\text { Mycorrhizal } \\
\text { colonization }\end{array}$ & Hyphae length & $\begin{array}{c}\text { AMF } \\
\text { spores }\end{array}$ & EE-GRSP \\
\hline Hyphae length & ns & & & \\
AMF spores & $0.60^{+}$ & $0.88^{* *}$ & & \\
EE-GRSP & $0.59^{+}$ & $0.88^{* *}$ & $0.85^{* *}$ & \\
WSA & ns & $0.84^{* *}$ & $0.81^{* *}$ & $0.82^{* *}$ \\
\hline
\end{tabular}

ns: not significant. ${ }^{+},{ }^{*}, * *, * * *$, significant at $P<0.1,0.05,0.01$ and 0.001 , respectively.

The nutritional parameters showed variations in relation to the $\mathrm{CC}$ treatments at 21 DAS (Fig. 3.3), but differences had generally disappeared by 52 DAS. Overall, maize after vetch tended to have the highest activity for both enzymes as well as the highest shoot $\mathrm{N}$ concentration and $\mathrm{N} / \mathrm{P}$ ratio, whereas the barley treatment had the highest shoot $\mathrm{P}$ concentration in the early stages of maize development. More specifically, $\beta$-glucosaminidase activity was higher in the vetch and barley treatments compared with fallow at 36 DAS (Fig. 3.3a). Phosphatase activity was higher in the vetch treatment compared with fallow at 21 and 36 DAS, with barley having intermediate values (Fig. 3.3b). By 52 DAS, there were no differences in enzyme activities between treatments. The highest shoot $\mathrm{P}$ was in 
the barley treatment and the lowest in the vetch at 21 DAS (Fig. 3.3c). Available soil P was higher in the fallow treatment than in both CC at 21 and 36 DAS (Fig. 3.3d). The ratio between shoot $P$ and available soil $P$ was larger for the maize after barley treatment than fallow at 21 DAS, and for both CC at 36 DAS $(P<0.1)$ (Fig.
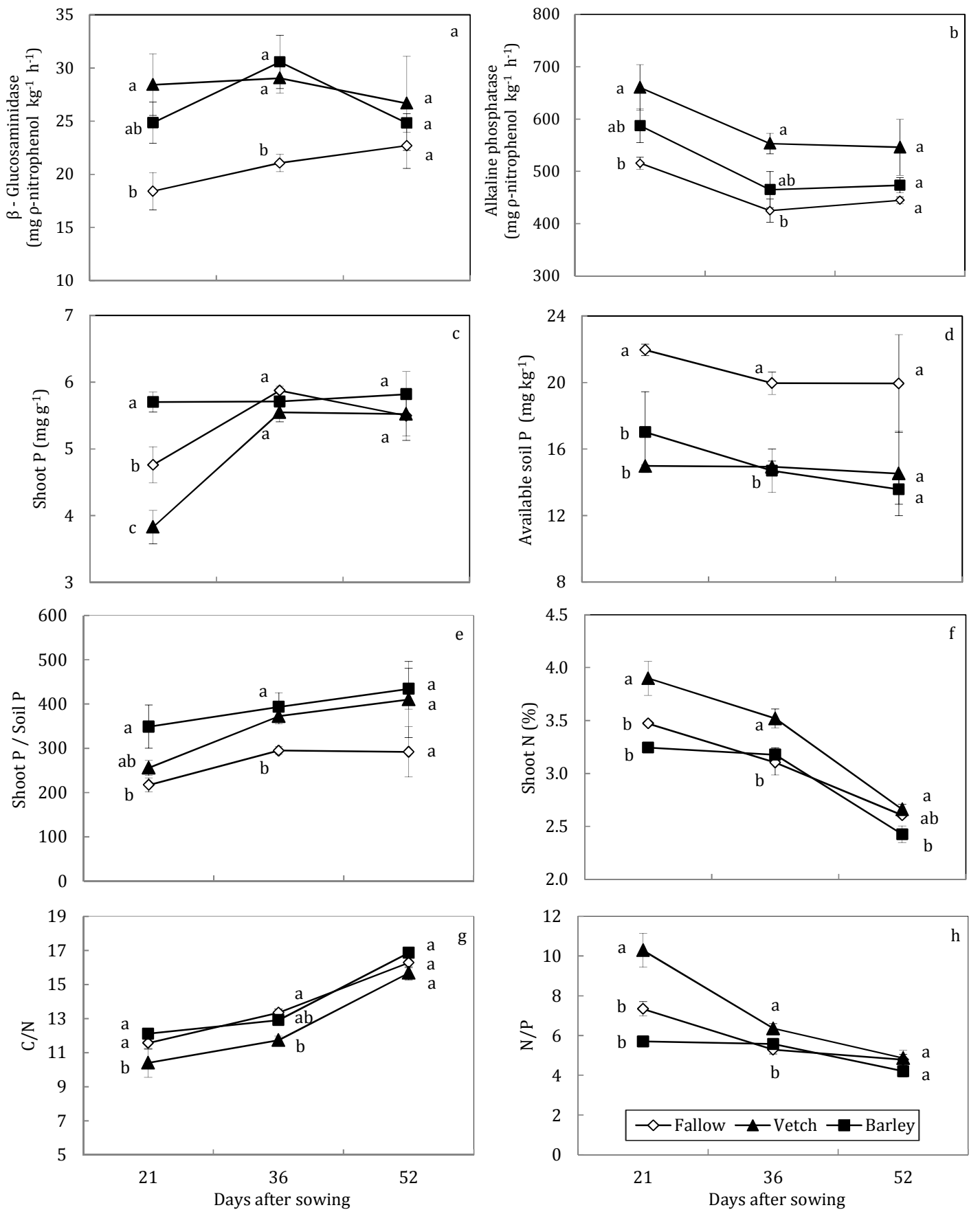

Fig. 3.3. Nutritional parameters in the soil ( $\beta$-Glucosaminidase and alkaline phosphatase activities and available soil $\mathrm{P}$ content) and in maize plants (Shoot $\mathrm{P}$ and $\mathrm{N}$ concentration and Shoot $\mathrm{P} /$ Soil $\mathrm{P}, \mathrm{C} / \mathrm{N}$ and $\mathrm{N} / \mathrm{P}$ ratios). Different letters for a given date indicate significant differences between treatments at $P<0.05$, according to Fisher's LSD test. Bars indicate SE. 
3.3e). Compared with fallow, the shoot $\mathrm{N}$ concentration was higher for the vetch treatment, whereas it was lower for barley at 21 DAS (Fig. 3.3f). Shoot $\mathrm{N}$ concentration diminished with time in all treatments and tended to merge, although barley still had the lowest values at 52 DAS. By contrast, the $\mathrm{C} / \mathrm{N}$ ratio increased with time, being lowest for vetch at 21 DAS and equal for all treatments by 52 DAS (Fig. 3.3g). The C/P (data not shown) and N/P (Fig, 3.3h) ratios followed similar patterns, inverse to those of $\mathrm{C} / \mathrm{N}$. The $\mathrm{N} / \mathrm{P}$ ratio was particularly interesting because there were differences between treatments up to 36 DAS. As expected from the shoot $\mathrm{P}$ concentration, vetch had the largest N/P ratio and barley the lowest, although all treatments had similar values by 52 DAS.

Mycorrhizal colonization was strongly correlated with the nutritional parameters at 21 DAS (Table 3.2), contrary to the weak correlations found with the rest of AMF parameters and the WSA. By contrast, the other AMF parameters were barely correlated, except for the positive relationships with shoot $\mathrm{P} /$ soil $\mathrm{P}$ and between EE-GRSP and shoot P. With respect to the enzymatic activities (data not shown), $\beta$-glucosaminidase activity was correlated with mycorrhizal colonization at 52 DAS $\left(r=0.77^{* *}\right)$ and AMF spores at 36 DAS $\left(0.62^{+}\right)$.

Table 3.2. Pearson correlation ( $\mathrm{r}$ ) between the arbuscular mycorrhizal fungi (AMF) parameters: mycorrhizal colonization, hyphae length, arbuscular mycorrhizal fungi spores and easily extractable glomalin-related soil protein (EE-GRSP) and the nutritional parameters at 21 days after sowing.

\begin{tabular}{ccccc}
\hline & $\begin{array}{c}\text { Mycorrhizal } \\
\text { colonization }\end{array}$ & $\begin{array}{c}\text { Hyphae } \\
\text { length }\end{array}$ & $\begin{array}{c}\text { AMF } \\
\text { spores }\end{array}$ & EE-GRSP \\
\hline Shoot P & $0,82^{* *}$ & ns & ns & $0,69^{*}$ \\
Available soil P & ns & ns & $-0.61^{+}$ & ns \\
Shoot P/Soil P & $0.79^{*}$ & $0,64^{+}$ & $0,84^{* *}$ & $0,73^{*}$ \\
Shoot N & $-0,81^{* *}$ & ns & ns & ns \\
C/N & $0.71^{*}$ & ns & ns & ns \\
N/P & $-0,83^{* *}$ & ns & ns & ns \\
\hline ns: not significant. ${ }^{*}{ }^{*}, * *, * * *$, significant at $P<0.1,0.05,0.01$ and 0.001, respectively
\end{tabular}

The height of maize plants varied between treatments. The highest maize plants were in the vetch and barley treatments (Table 3.3). No significant differences in the maize yield and biomass at harvest were found between 
treatments (Table 3.4). In addition, the $\mathrm{N}$ and $\mathrm{P}$ contents of maize grains did not vary between treatments.

Table 3.3. Mean height of maize plants at 79, 87 and 95 days after sowing (DAS).

\begin{tabular}{cccc}
\hline Cover & \multicolumn{3}{c}{ Height $(\mathrm{m})$} \\
\cline { 2 - 4 } & 79 DAS & 87 DAS & 95 DAS \\
\hline Fallow & $1.5 \pm 0.04 \mathrm{~b}$ & $1.9 \pm 0.03 \mathrm{c}$ & $2.2 \pm 0.04 \mathrm{~b}$ \\
Vetch & $1.9 \pm 0.07 \mathrm{a}$ & $2.4 \pm 0.05 \mathrm{a}$ & $2.5 \pm 0.07 \mathrm{a}$ \\
Barley & $1.7 \pm 0.04 \mathrm{a}$ & $2.1 \pm 0.06 \mathrm{~b}$ & $2.4 \pm 0.06 \mathrm{a}$ \\
\hline
\end{tabular}

Values indicate means and standard errors. Different letters within a column indicate significant difference between treatments at $P<0.05$, according to Fisher's LSD test.

Table 3.4. Mean biomass and yield of maize plants and $\mathrm{N}$ content of maize grains at harvest.

\begin{tabular}{ccccc}
\hline Cover & Biomass $\left(\mathrm{kg} \mathrm{ha}^{-1}\right)$ & Yield $\left(\mathrm{kg} \mathrm{ha}^{-1}\right)$ & Grain N $\left(\mathrm{kg} \mathrm{ha}^{-1}\right)$ & Grain P $\left(\mathrm{kg} \mathrm{ha}^{-1}\right)$ \\
\hline Fallow & $6791 \pm 731.8 \mathrm{a}$ & $8758 \pm 943.8 \mathrm{a}$ & $102.9 \pm 10.0 \mathrm{a}$ & $69.6 \pm 2.5 \mathrm{a}$ \\
Vetch & $8594 \pm 652.7 \mathrm{a}$ & $11083 \pm 841.8 \mathrm{a}$ & $131.9 \pm 12.8 \mathrm{a}$ & $75.2 \pm 14.7 \mathrm{a}$ \\
Barley & $7590 \pm 820.8 \mathrm{a}$ & $9789 \pm 1058.6 \mathrm{a}$ & $115.4 \pm 16.3 \mathrm{a}$ & $61.7 \pm 8.8 \mathrm{a}$ \\
\hline
\end{tabular}

Values indicate means and standard errors. Different letters within a column indicate significant difference between treatments at $P<0.05$, according to Fisher's LSD test.

\subsection{DISCUSSION}

Overall, our study showed a stimulation of AMF activity with the replacement of fallow by barley CC: the length of the extraradical mycelium, number of spores and EE-GRSP were greater for all sampling dates and mycorrhizal colonization was greater than for fallow 21 DAS. These results are in agreement with other field experiments, in which the use of grass CC such as winter wheat (Boswell et al., 1998; Kabir and Koide, 2000), oat and rye (Kabir and Koide, 2002; White and Weil, 2010) increased mycorrhizal colonization in the subsequent maize crop. Results also confirmed previous findings in the same long-term experiment, in which the use of barley as a CC improved the length of hyphae and AMF spores in the subsequent sunflower crop as well as the mycorrhizal colonization in maize (García-González et al., 2016b). Despite the well known benefits to rhizobium activity and the extra $\mathrm{N}$ contribution to the soil that makes vetch a common $\mathrm{CC}$, our results did not show any benefits to the AMF activity in the vetch treatment. However, other studies have shown that the incorporation of a legume as CC 
increased mycorrhizal colonization, compared with fallow (Deguchi et al., 2007; Njeru et al., 2014; Sorensen et al., 2005). Further, in the meta-analysis study by Bowles et al. (2016) concluded in that legume CC provided higher increases in mycorrhizal colonization compared with grasses. Our findings suggest that barley roots are better than vetch at retaining the indigenous AMF potential during the winter period. This is in agreement with results from the Netherlands, where legume CC did not enhance mycorrhizal colonization when compared with fallow or other grasses (chapter 4 of this thesis). There is, therefore, a need to clarify the effect of legume CC on mycorrhization of the subsequent crop. In view of the benefits of both crops, we recommend mixtures of grass-legume CC as a good option to stimulate the soil AMF and rhizobium activity in the subsequent maize crop.

In this study we confirm that EE-GRSP content may be included in the group of AMF indicators, since this protein was affected by CC in a similar way to the rest of the AMF parameters, with which it had remarkably positive correlations. The glomalin stimulation that we found for the barley CC is in line with other studies where the use of grass CC gave higher glomalin content than the legume and fallow (Balota et al., 2014a; Rillig et al., 2002). The higher WSA after barley and the strong relationships with glomalin content and mycorrhizal propagules in the soil reinforce the important role of AMF for soil stability (Bedini et al., 2009; GarcíaGonzález et al., 2016b; Kabir and Koide, 2002; Peng et al., 2013). The effect of CC on soil aggregation may be partially attributed, therefore, to AMF stimulation.

The evolution of AMF parameters did not present any relevant increase or decrease over time. This effect might be due to the favorable weather conditions at the time of sowing maize in 2014 that boosted the infection to very high values during the early maize stages, thus making subsequent increases difficult. By contrast, in 2013, García-González et al. (2016b) observed an increase in mycorrhizal colonization and length of hyphae between 54 and 69 DAS. In that year, the levels of mycorrhizal colonization at 54 DAS (52-72\%) were very low compared with those for 2014 at 21 DAS (81-91\%). The evolution of AMF parameters over time may, therefore, be influenced by the environmental 
conditions during each campaign. Despite the high values, there were significant differences between the mycorrhizal colonization for the different $\mathrm{CC}$, but only for the first sampling date. These findings are in agreement with other studies that have found differences in mycorrhizal colonization due to CC treatments at the beginning of the study that then disappeared over time (Deguchi et al., 2007; White and Weil, 2010). But, they disagreed with Bowles et al. (2016) who found no effect of sampling time on mycorrhizal colonization. The choice of sampling dates is, therefore, crucial for evaluating the treatment effect on mycorrhizal colonization. By contrast, the other AMF parameters tended to maintain consistent differences between treatments throughout the study.

Cover crops enhanced $\beta$-glucosaminidase activity, in agreement with the enzymatic increments attributed to an additional supply of biomass into the soil (Ekenler and Tabatabai, 2003; Mbuthia et al., 2015; Zhao et al., 2016). The positive relationship $\left(\mathrm{r}=0.78^{*}\right)$ between $\beta$-glucosaminidase activity and mycorrhizal colonization found for the third sampling date suggests that the higher values found for the barley treatment might also be related to AMF. In the case of vetch, the higher activity cannot be associated with AMF since this CC did not stimulate AMF compared with fallow. The connection between $\beta$-glucosaminidase and AMF still seems unclear and new studies are needed to confirm their relationship and interaction.

The enhancement of alkaline phosphatase activity with respect to fallow may be attributed to the increase of organic matter provided by the vetch CC (data not shown) (García-González et al., 2016a). Nevertheless, barley also increased organic matter and even provided more aboveground biomass for decomposition, but the effect on alkaline phosphatase activity was not evident. Legumes as vetch seem to play a special role in the stimulation of this enzyme. Balota et al. (2014a) and HaiMing et al. (2014) found that replacing fallow by a vetch CC in crop rotations enhanced alkaline phosphatase activity; whereas the effect of grasses as CC on the enzyme activity was not clear. Rhizobium nodules are known to have a high $\mathrm{P}$ content (Olivera et al., 2004) and, therefore, a possible explanation is that the organic $\mathrm{P}$ is released into the soil after the legume crop, thereby enhancing alkaline phosphatase activity. The highest enzyme activity did not translate immediately in 
a higher $\mathrm{P}$ concentration in maize shoots or soil available $\mathrm{P}$, most likely as a result of competition with soil microorganisms for P uptake (White and Ayoub, 1983). However, shoot $\mathrm{P}$ concentration in the vetch treatment recovered by the time of the next sample. With respect to the connection between the alkaline phosphatase activity and AMF reported by Joner and Jakobsen (1995) and Marschner and Baumann (2003), we found no evidence in our study of an influence of AMF on the activity of this enzyme.

The lower soil available P in CC treatments with respect to fallow was due to plant uptake during the fall-winter period (Cavigelli and Thien, 2003) even though the $\mathrm{P}$ concentration was higher in maize after barley. The shoot $\mathrm{P}$ in the barley treatment was higher than in fallow and vetch (by 20\% and 59\%, respectively) in the first stage (21 DAS). With the passing of the time, shoot P values in the rest of treatments tended to become equal to those of barley, meaning that maize after barley had a greater capacity for absorbing soil P in the early stages. This is backed up by the higher shoot $\mathrm{P} /$ soil $\mathrm{P}$ ratio found in the barley treatment. It may be due to the greater length of extraradical mycelium and mycorrhizal colonization in that treatment (39\% more than fallow and $12 \%$ more than vetch, respectively) and its positive correlation with mycorrhizal colonization $\left(0.82^{* *}\right)$. In addition, the positive relationships between all the AMF parameters and the shoot $\mathrm{P} /$ soil $\mathrm{P}$ ratio backs up this relationship between $\mathrm{P}$ acquisition and AMF. Thus, despite the phosphoric fertilization, the increased presence of AMF outside and inside maize roots after barley dramatically increased the surface area for nutrient exploration and P uptake (Marschner and Dell, 1994). These results are in agreement with Kabir and Koide $(2000,2002)$ who showed an increase of $P$ content in maize plants after CC (dandelion, rye, oat and rye-oat) and positive relationships with AMF parameters (root length colonized by mycorrhiza and density of mycorrhizal hyphae) at 25-27 DAS maize. White and Weil (2010) also found higher maize shoot $\mathrm{P}$ after rye with respect to fallow and it was also positively correlated with AMF colonization. In a more detailed experiment, Van Der Heijden et al. (2006) found higher shoot $\mathrm{P}$ in treatments inoculated with AMF compared with those without AMF. 
Crop N uptake may be improved by AMF (Jin et al., 2005; Smith and Read, 2008; Tanaka and Yano, 2005) and represents a significant nutritional benefit to the plant. However, contrary to our expectations, the treatment with the highest mycorrhizal activity, barley $\mathrm{CC}$, had the lowest $\mathrm{N}$ concentration in the maize plants. Miller et al. (2002) found similar results for grass biomass, with lower $\mathrm{N}$ contents in mycorrhizal plants than in non-mycorrhizal plants. Also, Van Der Heijden et al. (2006) did not find any enhancement of total $\mathrm{N}$ in plants inoculated with AMF. We, in addition, found negative correlations between shoot $\mathrm{N}$ and AMF parameters. The variety of results suggests that there is no definitive conclusion regarding the relationship between $\mathrm{N}$ uptake and AMF presence (Veresoglou et al., 2012).

Our results show that the treatment with the highest shoot $\mathrm{N}$ was vetch, which can be explained by the capability of the legume to fix atmospheric $\mathrm{N}_{2}$. A higher topsoil $\mathrm{N}$ availability in the vetch plots (16.5 $\mathrm{kg} \mathrm{N} \mathrm{ha}^{-1}$ ) compared with barley (11.3 $\mathrm{kg} \mathrm{N} \mathrm{ha}^{-1}$ ) was found in April just before maize sowing (Gabriel et al., 2016). This extra N supply by the legume might be one of the explanations for the relatively low mycorrhizal activity in this treatment. Mycorrhizal colonization becomes less indispensable when the plant can easily obtain the necessary $\mathrm{N}$ (Mbuthia et al., 2015). In the presence of available nutrients, the plant, therefore, saves the high $\mathrm{C}$ cost required to maintain AMF.

The decrease in shoot $\mathrm{N}$ with plant age or biomass followed the well known $\mathrm{N}$ dilution curve (Greenwood et al., 1990). Accordingly, the $\mathrm{C} / \mathrm{N}$ ratio increased over the three sampling dates and the $\mathrm{N} / \mathrm{P}$ ratio followed the opposite pattern. Koerselman and Meuleman (1996) suggested that problems with nutrient availability and limitations in plant growth could occur if the $\mathrm{N} / \mathrm{P}$ ratio in the above-ground biomass of maize is below 14 or above 16 . In our study, the N/P ratios ranged from 4 to 10 , so it seems that $\mathrm{N}$ was a limiting factor for maize growth. This is consistent with the suspension of $\mathrm{N}$ fertilization in the three previous campaigns. Maize after vetch had a higher $\mathrm{N} / \mathrm{P}$ ratio than the other treatments but it was still lower than 14 , which means that the $\mathrm{N}$ fixed by the vetch was not enough to supply crop requirements. 
In our study, the average maize height was consistently higher after vetch and barley than after fallow. The greater height in these treatments might be due to the nutrient contribution of the $\mathrm{CC}$, especially the $\mathrm{N}$ input from the legume residues, together with those coming from the mineralization of the organic matter, whose content was enhanced by both CC (García-González et al., 2016a). In addition, the enhancement of mycorrhizal activity in the barley treatment probably increased the maize height, as suggested by Kabir and Koide (2002), although no correlation was found between AMF parameters and plant height. However, the positive effect of $\mathrm{CC}$ on maize height did not lead to any significant effect on either the maize biomass at harvest or yield, although the order of both parameters tended to follow the pattern: vetch > barley > fallow. Likewise, Gabriel et al. (2016) did not find any effect on maize yield or biomass from CC in 2013 and 2014 in microplots established in the same trial but emphasized that the main benefit was a reduction of $\mathrm{N}$ fertilizer application after vetch. In the field experiment by White and Weil (2010), there was no correlation between AMF colonization and maize yield. By contrast, other studies have observed a significant increase in maize yield after various CC (Boswell et al., 1998; Deguchi et al., 2007; Kabir and Koide, 2002). In the present study we found a tendency for higher biomass and yield in maize after CC, particularly after vetch, but the effect was not strong enough to produce significant differences. These results suggest that there was another limiting factor during the cropping season (i.e. high temperatures at flowering or water stress) that prevented the benefits from AMF to be translated into a yield response.

\subsection{CONCLUSIONS}

Replacing the traditional winter fallow by a barley cover crop improved the AMF activity in the subsequent maize crop and, as a consequence, increased soil aggregation and shoot $\mathrm{P}$ concentration. The replacement by vetch did not enhance any of the mycorrhizal parameters in the following maize, giving similar results to the fallow treatment. Mycorrhizal colonization, a commonly used AMF parameter, depended on sample date and, therefore, should be complemented with other AMF 
parameters (i.e. length of hyphae, AMF spores and EE-GRSP) that were more sensitive to treatment differences over time.

Whilst mycorrhizal colonization was related to nutrient parameters, the aggregate stability was stimulated by an increased abundance of AMF hyphae and spores that, in turn, increased glomalin production. Therefore, part of the benefits to soil stability provided by the CC is via AMF stimulation. Soil enzymatic activities and nutritional parameters in maize plants were sensitive to the use of CC, particularly on the first sampling date. Despite $\mathrm{P}$ fertilization and low $\mathrm{N}$ availability, the AMF enhancement provided by the barley CC increased shoot $\mathrm{P}$ concentration in the early maize growth stages, but did not affect shoot $\mathrm{N}$ concentration.

Although CC increased the height of maize plants and AMF improved $\mathrm{P}$ concentrations, no significant differences in yield were observed. In our irrigated maize cropping system under a Mediterranean climate, the main benefits of introducing cover crops were related to an enhancement of soil quality and nutrient supply rather than to an increased yield of the subsequent maize crop. 
Chapter 4

Legacy effects of cover crop monocultures and mixtures on mycorrhizal colonization in subsequent crops 



\subsection{INTRODUCTION}

The cultivation of cover crops (CC) during fall and winter is a common agronomic practice. Cover crops add organic matter to the soil, improve nutrient cycling, reduce nutrient leaching in between cropping periods, control weed growth, suppress soil-borne diseases, and keep the soil protected against wind and water erosion (Clark, 2008; Dabney et al., 2001; Snapp et al., 2005). Cover crops can thus improve the physical, chemical and biological properties of the soil, resulting in increased biomass production of the subsequent crop (Munkholm and Hansen, 2012). Important biological changes in soil due to cover crops comprise of impacts on soil pathogens (Abawi and Widmer, 2000) as well as on beneficial soil born organisms such as arbuscular mycorrhizal fungi (AMF) (Lehman et al., 2012). The AMF live in symbiosis with most plant species and provide numerous advantages to host plants, such as improving nutrient uptake especially of poorly mobile nutrients, and increasing plant tolerance to biotic and abiotic stress factors (Smith and Read, 2008).

Arbuscular mycorrhizal fungi are strictly biotrophic and therefore a fallow period or the cultivation of a non-host crop is expected to reduce the AMF inoculum potential of the soil for the following grown plants. Earlier studies found that the absence of host plants (i.e. fallow soil) or the growth of a non-host species before the main crop can lead to a decline in the viability of AMF, with reductions of $40 \%$ without host and of $13 \%$ with mustard, a non-host, as compared with growth of a good AMF host such as cowpea (Harinikumar and Bagyaraj, 1988). Replacing fallow with a CC that is an AMF host can thus promote AMF inoculum potential for the subsequent crop (Galvez et al., 1995). However, other studies reported that AMF spores and extra-radical mycelia are able to survive winter fallow and maintain colonization potential for the next crop (Lekberg and Koide, 2008; McGonigle and Miller, 1999), suggesting that the impact of CC to improve AMF inoculum compared with fallow is dependent on several factors with an important role for CC species used.

Many commonly used CC species belong to the Poaceae (grasses) or Fabaceae (legumes) families. Several studies, covering a range of different crop and CC 
species, have reported that legume CC can enhance the AMF viability and improve AMF colonization in the subsequent crop. For example, the legume CC white clover (Deguchi et al., 2007) and hairy vetch (Njeru et al., 2014) were found to stimulate AMF colonization in the following maize crop as compared with maize grown after fallow. The reason for the stimulatory effects of legume species on AMF colonization in subsequent crops may be the synergistic character of the relationship between the $\mathrm{N}_{2}$-fixing bacteria, present in legumes, and AMF (FreyKlett et al., 2007). Also grass CC species can promote AMF establishment in the subsequent main crop, relative to growing crops after fallow. For example, wheat (Boswell et al., 1998), rye (White and Weil, 2010) and the mixture of oats and rye (Kabir and Koide, 2002) as CC resulted in increased AMF colonization in roots of subsequently grown maize. Taken together these studies suggest that growing grass-legume mixtures as CC may be beneficial in terms of stimulating AMF colonization, in addition to the often reported benefits of grass-legume mixtures for build-up of soil organic matter and $\mathrm{N}$ in soil (Snapp et al., 2005). This idea is supported by the study of Chen et al. (2005) who found higher AMF infection rates and spore density with grass and legume mixtures than in their respective monocultures.

Plant species from the Brassicaceae family are often used as CC because of their fast growth, good soil cover and pest control; however these plants are known as non-host plants for AMF (Wang and Qiu, 2006). Moreover Brassicaceae plants produce glucosinolates, which are metabolized to isothiocyanates (ITC) in the rhizosphere and can act as inhibitor of fungi, including AMF (Fahey et al., 2001). As a result, AMF colonization in subsequently grown crops can be reduced due to low AMF inoculum potential. Several studies indeed found lower AMF colonization in the subsequent crop after a Brassicaceae crop as compared with after mycorrhizal crops (Isobe et al., 2014; Karasawa et al., 2001; Koide and Peoples, 2012). Also reduced levels of AMF colonization were found in the following maize crop in studies using Brassicaceae as CC, although no difference was found between maize after fallow or after the Brassicaceae, suggesting that the Brassicaceae species do not always actively suppress AMF (Njeru et al., 2014; White and Weil, 2010). Similar results were achieved when the effect on AMF 
propagules were measured by the most-probable-number assay in soil with a Brasicaceae cover crop versus fallow or AMF host cover crops (Lehman et al., 2012). These results indicate that the additional inhibitory effect of Brassicaceae on AMF beyond the merely reduction of AMF derived from its non-host AMF condition warrants further elucidation.

In order to mitigate the non-host or even AMF suppressive effect of Brassicaceae species it has been suggested than one could mix in AMF host plant species to counteract AMF suppressive effects of Brassicaceae CC species (Chen et al., 2005). However, studies taking this approach failed (White and Weil, 2010), or partially failed (Lehman et al., 2012) to maintain high AMF inoculum potential by using mixtures of AMF hosts and Brassicaceae as CC, or when using AMF hosts intercropped with a Brassicaceae in a rotation (Haider, 2014). To date the underlying mechanisms remain unclear and there are few studies investigating the legacy effects of several monocultures and species mixtures of commonly used cover crops on AMF colonization, and also on other main crops than maize. Therefore, the role of CC species mixtures versus that of the identity of CC species monocultures on AMF colonization in subsequently grown grain (other than maize) and vegetable crops remains unclear.

In our field study, we used four common CC of three plant families (Fabaceae, Poaceae, Brassicaceae) to test the legacy effects of CC monocultures and mixtures on AMF colonization in a subsequently grown grain (oat) and vegetable (endive) crop. We hypothesized that 1) relative to fallow, legume and grass cover crops increase, and Brassicaceae (radish) decrease AMF colonization in the subsequent main crops, and that 2) mixtures of a legume and a Brassicaceae counterbalance AMF suppressive effects of the Brassicaceae species.

\subsection{MATERIALS AND METHODS}

\subsubsection{Experimental design}

The experiment was performed at the field facilities of Wageningen University (Nergena, Wageningen, The Netherlands, 5159'41.9"N 5³9'17.5"E). 
The climate of this area is temperate oceanic (Köppen, 1900) with annual mean temperature of $10.9{ }^{\circ} \mathrm{C}$ and an annual precipitation of $853.3 \mathrm{~mm}$ in 2015 (Royal Netherlands Meteorological Institute). Prior to establishment of the experiment the field was cultivated with Phacelia tanacetifolia Benth. var. Angelia (summer 2013) to limit effects of cultivation history. The plants were mown in August and the residues were left on the field. The field was ploughed $(0-25 \mathrm{~cm})$ in March 2014 in preparation of the experiment. The site had soil characteristics typical of degraded Spodosols, sandy soil (1\% clay, 4\% silt, 91\% sand and 4\% organic matter) with $\mathrm{pH} 5.8$ that at the start of the experiment had following nutrient levels in the top $25 \mathrm{~cm}$ : total $\mathrm{N} 1310 \mathrm{mg} \mathrm{kg}^{-1}$, total P $284 \mathrm{mg} \mathrm{kg}^{-1}$ and total $\mathrm{K} 93.6$ mg kg-1.

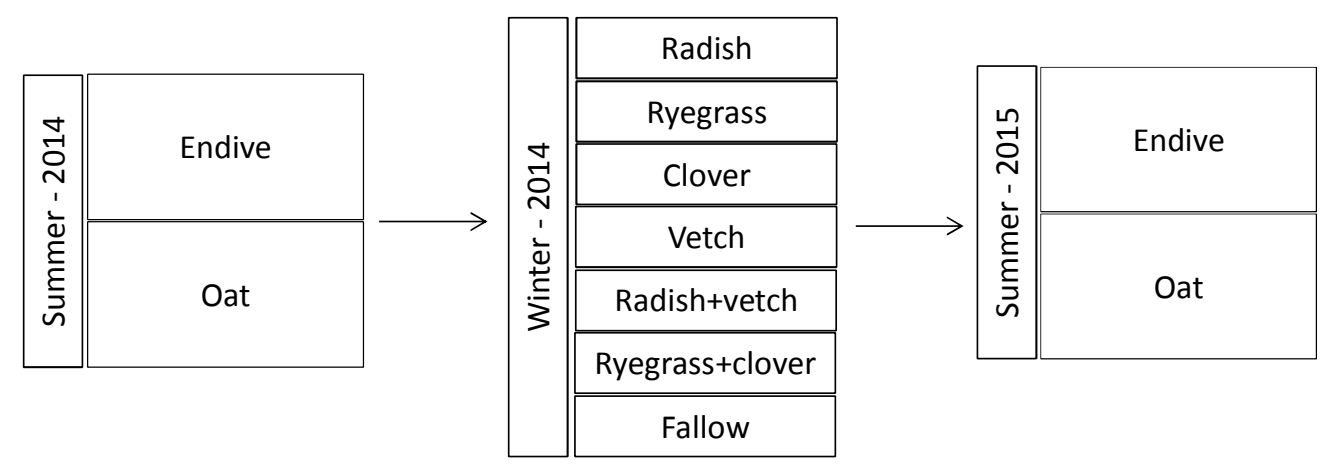

Fig. 4.1. Schematic of the field experimental design, divided into three phases.

The experimental area was established in March 2014; 120 plots of $3 \mathrm{~m} \mathrm{x} 3 \mathrm{~m}$ were laid out in a randomized block design with five blocks. Each plot consisted of two experimental units $(1.5 \mathrm{~m} \times 3 \mathrm{~m})$. The plots were separated by $1.5 \mathrm{~m}$ wide grass strips (Phleum pratense L.). The design included factorial comparison of rotations in three-phases (summer crops 2014, winter cover crops 2014 and summer crops 2015 being the test crops) (Fig. 4.1). The crops grown in 2014 were oats (Avena sativa L. var. Dominik) and endive (Cichorium endivia L. var. Nummervijf2), each on twelve random plots in each of the five blocks. On each plot the crop was followed by one of seven CC treatments: fallow, perennial ryegrass (Lolium perenne L. var. Mathilde), white clover (Trifolium repens L. var. Alice), common vetch (Vicia sativa L. var. Ebena) and radish (Raphanus sativus L. var. Terranova), and the mixtures ryegrass+clover and radish+vetch. Monoculture and 
fallow treatments were applied on full plots, the mixtures ryegrass+clover and radish+vetch were grown in one randomly allotted experimental unit within the plots assigned to mixtures. In the third phase, test crops endive and oats were grown following the winter cover crops (Fig. 4.2).

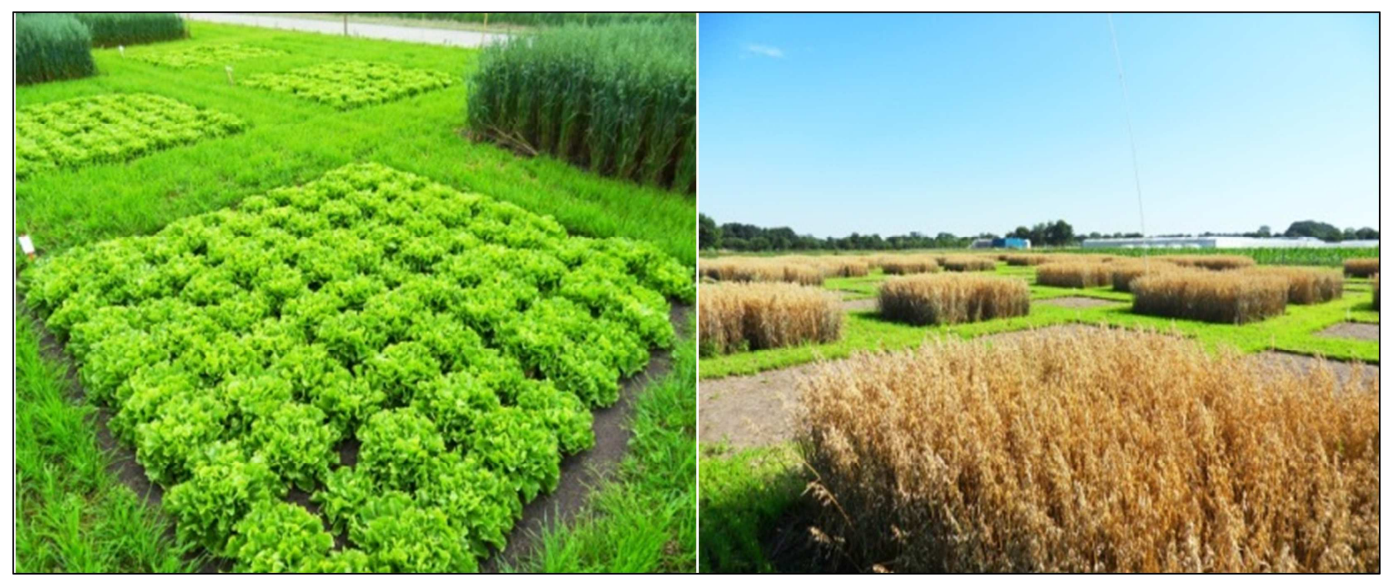

Fig. 4.2. Endive and oats crops in summer 2015 at Wageningen University field.

\subsubsection{Field management}

In preparation of the first summer rotation in 2014 the experimental field was fertilized in March with $82 \mathrm{~kg} \mathrm{~N} \mathrm{ha}^{-1}, 300 \mathrm{~kg} \mathrm{~K}_{2} \mathrm{O}$ ha-1$^{-1}, 420 \mathrm{~kg} \mathrm{SO}_{3} \mathrm{ha}^{-1}, 118 \mathrm{~kg}$ $\mathrm{CaO}_{\mathrm{ha}^{-1}}$, as calcium-ammonium nitrate, potassium sulphate and gypsum and the

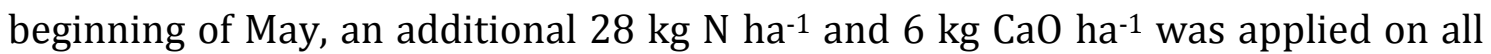
plots. In the first week of April, oats was sown on half of the plots, (430 seeds $\mathrm{m}^{-2}$; $12.5 \mathrm{~cm}$ row spacing, 3-5 cm depth) and endive seedlings were transplanted on the remaining plots (100 individuals per plot, $30 \mathrm{~cm}$ apart) on May 8. Three days prior to endive planting plots were treated against dicot weeds with the herbicides Damine (2,4-dichlorophenoxyacetate, $1000 \mathrm{~g}$ ha-1), MCPA (4-chloro-2methylphenoxyacetate, $500 \mathrm{~g} \mathrm{ha}^{-1}$ ) and Starane (fluroxypyr-meptyl, $288 \mathrm{~g} \mathrm{ha}^{-1}$ ) and later weed growth was kept in check by hand weeding. Throughout May and June all plots were irrigated according to general agricultural practice to ensure optimal growth conditions. Above ground biomass of endive was harvested July 10 and oats on July 28, the remaining stubbles were hoed and left on the field. At the end of August 2014, the plots were hoed by hand and CC were sown in rows with 12.5 
cm row spacing. The four monocultures were sown in a density used in common agricultural practice (ryegrass $25 \mathrm{~kg} \mathrm{ha}^{-1}$; clover $10 \mathrm{~kg} \mathrm{ha}^{-1}$; vetch $125 \mathrm{~kg} \mathrm{ha}^{-1}$; radish $30 \mathrm{~kg} \mathrm{ha}^{-1}$ ) and the mixtures were sown in 1:1 proportion of their monocultures seed densities. After three weeks, the plots were weeded by hand. In preparation of the main crops, the CC were mown mid-February and the residues incorporated into the soil (0-15 $\mathrm{cm}$ depth) by a small superficially tilling machine. The plots were fertilized with $41 \mathrm{~kg} \mathrm{~N} \mathrm{ha}^{-1}, 245 \mathrm{~kg} \mathrm{~K}_{2} \mathrm{O} \mathrm{ha}^{-1}, 343 \mathrm{~kg} \mathrm{SO}_{3} \mathrm{ha}^{-1}, 9 \mathrm{~kg}$ $\mathrm{CaO} \mathrm{ha}^{-1}$ in March, and additionally $14 \mathrm{~kg} \mathrm{~N} \mathrm{ha}^{-1}$ and $3 \mathrm{~kg} \mathrm{CaO} \mathrm{ha}^{-1}$ were applied in May, as calcium-ammonium nitrate and potassium sulphate. Oats were sown on March 19, endive seedlings were planted on May 7 and herbicides were used a few days before planting to kill dicot weeds. The plots were irrigated as needed during May and June. Throughout the season the plots were hand weeded.

\subsubsection{Data collection}

Soil samples for nutrient analysis at the start of the experiment were collected from across the field site with an auger $(0-30 \mathrm{~cm}, 2.5 \mathrm{~cm}$ diameter $)$ and bulked and analyzed according to standard procedures by BLGG AgroXpertus. The root samples to investigate AMF colonization were collected on June 17 during the second main crop growth, from within one experimental unit (1.5 m x $3 \mathrm{~m}$ ) at twelve different points in oats plots and at nine points in endive plots across the length of three planting rows ( $3 \mathrm{~m}$ long, $15 \mathrm{~cm}$ between each row) and keeping 30 $\mathrm{cm}$ from the plot borders. To collect the roots we used an auger of $1 \mathrm{~cm}$ diameter and to $15 \mathrm{~cm}$ depth and sieved and washed the roots from this bulk sample. To visualize the AMF, the roots were stained with ink and vinegar according to standard protocol (Vierheilig et al., 1998) and the percentage of AMF structures was determined using a light microscope to evaluate roots mounted on slides according to the gridline intersection method (Giovannetti and Mosse, 1980). In each sample, the percentage of intraradical arbuscules, hyphae and vesicles were recorded. These percentages were calculated as: ( $n$ intersections with the AMF structure studied)/(y total intersections) x 100, with y being 100 or slightly over 100. The total mycorrhizal colonization was calculated as the sum of the intersection points of arbuscules, hyphae and vesicles. 


\subsubsection{Data analysis}

General linear mixed models were used to test the effect of the different main crops in 2014, the CC treatments and the interaction between main crop and CC on AMF colonization in the main crops endive and oat in 2015, with block as a random factor to capture random spatial variation. Prior to the analyses the percentages of total AMF colonization and of hyphae and vesicles were arcsin square root transformed to comply with the assumptions for normality and homogeneity of variance. Post-hoc differences were evaluated with LSD test at a 0.05 level of significance. The percentage of arbuscules was analyzed with a non-parametric model using the Kruskal-Wallis test and Mann-Whitney U test because this variable did not meet the assumptions for performing parametric tests. All statistical analyses were performed using SPSS 22 software, the results in tables and graphics represent the means and standard error of untransformed values.

\subsection{RESULTS}

\subsubsection{AMF colonization in endive roots in response to cover crop legacies}

The percentage of AMF colonization in the roots of endive differed significantly between the preceding CC treatments $\left(F_{6,52}=14.32, P<0.001\right)$ (Fig. 4.3a). Also the main crops of the year before affected the AMF colonization in endive, with more colonization on former oat plots than on former endive plots $\left(F_{1,52}=7.58, P=0.008\right)$ (Fig. $\left.4.3 \mathrm{~b}\right)$. There was no significant interaction between these factors, indicating that the effect of the CC on mycorrhizal colonization was not affected by the preceding crop. Overall ryegrass and the mixture ryegrass+clover $\mathrm{CC}$ resulted in increased AMF colonization in the endive roots compared with the fallow treatment. In contrast AMF colonization was lowest in roots of endive grown after radish CC, however these levels did not differ significantly from the $\mathrm{CC}$ treatments radish+vetch, vetch and fallow. 

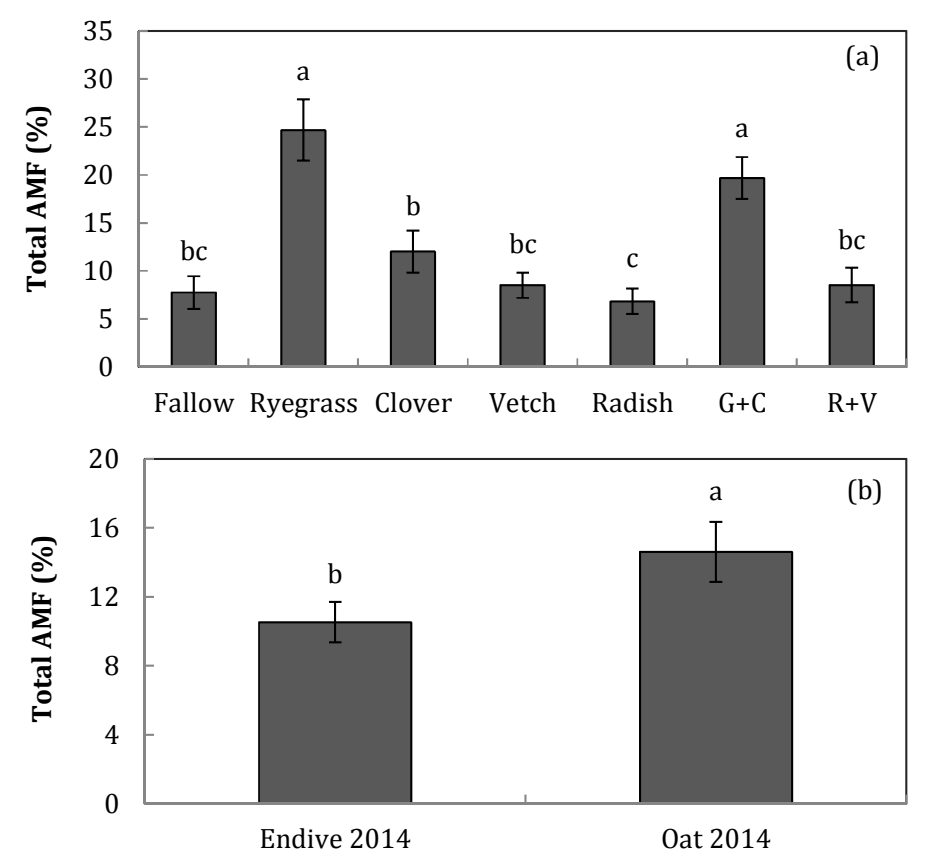

Fig. 4.3. Legacy effects of cover crops: ryegrass, white clover, common vetch, radish, ryegrass+clover $(\mathrm{G}+\mathrm{C})$ and radish+vetch $(\mathrm{R}+\mathrm{V})(\mathrm{a})$ and of the preceding main crop endive or oat $(\mathrm{b})$ on AMF colonization \% in endive roots. Different letters indicate significant differences among cover crops according to LSD test ( $\alpha=0.05$ probability level). Vertical bars represent SE; (a) $N=10$, (b) $\mathrm{N}=35$.

The effect of CC on AMF colonization in endive roots was also found in the different AMF structures, namely for arbuscules $\left(\chi^{2}=32.1, \mathrm{P}<0.001\right)$ and hyphae $\left(F_{6,52}=6.64, P<0.001\right)$ (Table 4.1). The highest level of AMF colonization in terms of percentage of arbuscules and hyphae was found in the roots of endive grown after ryegrass. The lowest colonization by arbuscules was found in roots of endive grown after fallow, vetch, radish and the mixture of radish+vetch. A similar result was found for the percentage of AMF hyphae, yet with lowest levels in roots of endive grown after radish or radish+vetch. Overall very few vesicles were found in the endive roots. 
Table 4.1. Cover crop legacy effects on colonization percentage of arbuscular mycorrhizal fungi (AMF) hyphae, arbuscules and vesicles in endive roots (mean \pm standard error; $\mathrm{N}=10$ ).

\begin{tabular}{cccc}
\hline Cover crop treatment & AMF Arbuscules (\%) & AMF Hyphae (\%) & AMF Vesicles (\%) \\
\hline Fallow & $3.5 \pm 1.0 \mathrm{c}$ & $4.0 \pm 0.9 \mathrm{~cd}$ & 0 \\
Ryegrass & $15.3 \pm 2.4 \mathrm{a}$ & $9.0 \pm 1.0 \mathrm{a}$ & $0.1 \pm 0.1$ \\
Clover & $6.1 \pm 1.6 \mathrm{bc}$ & $5.9 \pm 1.0 \mathrm{bc}$ & 0 \\
Vetch & $3.2 \pm 0.6 \mathrm{c}$ & $5.4 \pm 1.0 \mathrm{c}$ & 0 \\
Radish & $3.4 \pm 0.8 \mathrm{c}$ & $3.1 \pm 0.8 \mathrm{~d}$ & $0.1 \pm 0.1$ \\
Ryegrass+Clover & $11.4 \pm 1.5 \mathrm{ab}$ & $8.1 \pm 1.2 \mathrm{ab}$ & 0 \\
Radish+Vetch & $4.8 \pm 1.4 \mathrm{c}$ & $3.6 \pm 0.5 \mathrm{~cd}$ & $0.1 \pm 0.1$ \\
\hline
\end{tabular}

Different letters indicate significant difference among cover crops according to LSD test or KruskalWallis or Mann-Whitney U test at 0.05 probability level.

\subsubsection{AMF colonization in oat roots in response to cover crop legacies}

In oat roots, the percentage of mycorrhizal colonization was significantly affected by the CC treatments ( $\mathrm{F}_{6,52}=9.64, \mathrm{P}<0.001$; Fig. 4.4a). There was no significant effect of the main crop grown the previous year (Fig. 4.4b) nor a significant interaction between preceding crop and CC treatment. The oat roots were most densely colonized by AMF when grown after the $\mathrm{CC}$ treatments ryegrass or ryegrass+clover (Fig. 4.4a). In contrast, the CC treatments radish and radish+vetch compared with fallow resulted in a significant reduction of AMF colonization in oat roots.
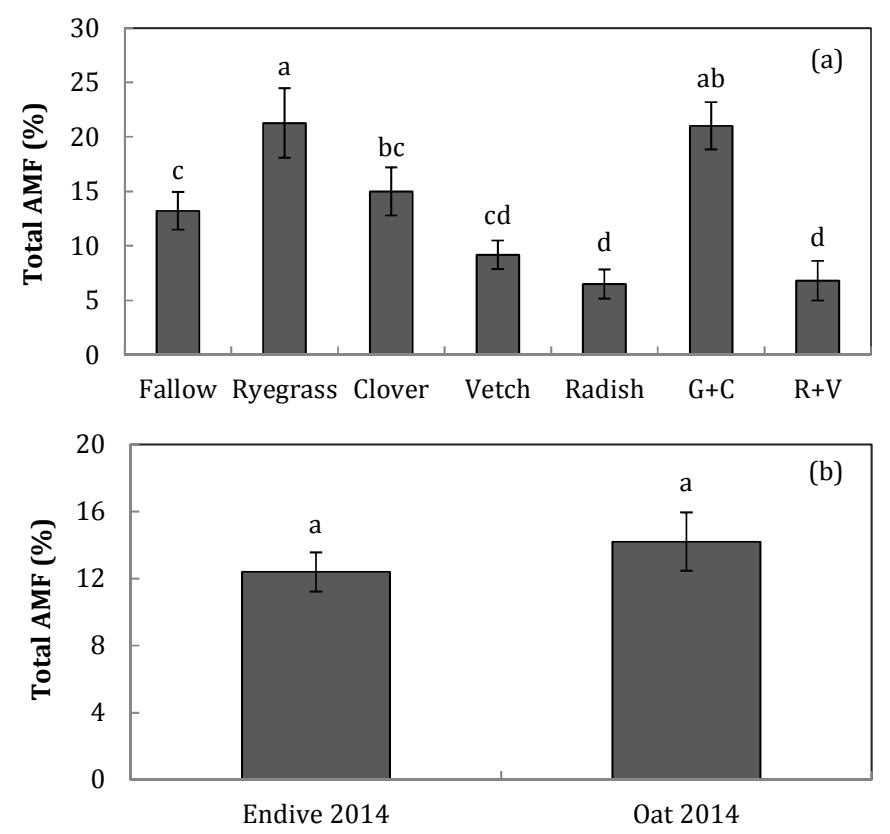

Fig. 4.4. Legacy effects of cover: ryegrass, white clover, common vetch, radish, ryegrass+clover $(\mathrm{G}+\mathrm{C})$ and radish+vetch $(\mathrm{R}+\mathrm{V})(\mathrm{a})$ and of the preceding main crop endive or oat (b) on AMF colonization $\%$ in oat roots. Different letters indicate significant differences among cover crops according to LSD test ( $\alpha=0.05$ probability level). Vertical bars represent SE; (a) N=10, (b) N= 35 . 
Among the CC treatments, the percentage of arbuscules in oat roots showed a trend of being stimulated by the legacy of the mixture ryegrass+clover, whereas the legacy of radish and radish+vetch significantly reduced the level of arbuscules as compared with fallow $\left(\chi^{2}=30.6, \mathrm{P}<0.001\right.$; Table 4.2). The effects of the CC on AMF hyphae colonization in oat roots were comparable to the effects on the arbuscules with lowest degrees of colonization when oat was grown after radish or after radish+vetch, and highest when grown after ryegrass or after the mixture ryegrass+clover $\left(\mathrm{F}_{6,52}=6.1, \mathrm{P}<0.001\right)$. Similarly to the results for endive, the density of vesicles was very low in the roots of oats.

Table 4.2. Cover crop effect on percentage colonization of arbuscular mycorrhizal fungi (AMF) hyphae, arbuscules and vesicles in oat roots (mean \pm standard error; $N=10$ ).

\begin{tabular}{cccc}
\hline Cover crop treatment & AMF Arbuscules (\%) & AMF Hyphae (\%) & AMF Vesicles (\%) \\
\hline Fallow & $6.7 \pm 1.1 \mathrm{bc}$ & $6.4 \pm 1.0 \mathrm{bc}$ & $0.1 \pm 0.1$ \\
Ryegrass & $10.5 \pm 1.6 \mathrm{ab}$ & $10.1 \pm 1.0 \mathrm{a}$ & $0.4 \pm 0.2$ \\
Clover & $8.6 \pm 1.6 \mathrm{ab}$ & $6.4 \pm 1.5 \mathrm{bc}$ & 0 \\
Vetch & $4.4 \pm 1.0 \mathrm{~cd}$ & $4.6 \pm 0.5 \mathrm{~cd}$ & 0 \\
Radish & $2.6 \pm 0.8 \mathrm{~d}$ & $3.9 \pm 1.1 \mathrm{~d}$ & 0 \\
Ryegrass+Clover & $11.7 \pm 1.6 \mathrm{a}$ & $9.2 \pm 1.8 \mathrm{ab}$ & $0.1 \pm 0.1$ \\
Radish+Vetch & $3.5 \pm 0.7 \mathrm{~d}$ & $3.3 \pm 0.6 \mathrm{~d}$ & 0 \\
\hline
\end{tabular}

Different letter indicate significant difference among cover crops according to LSD test or KruskalWallis test or Mann-Whitney U at 0.05 probability level.

\subsection{DISCUSSION}

The results of this 2-year field experiment show that the identity of the CC species and species mixture is of importance for the level of AMF colonization in subsequently grown vegetable and grain crops. In addition, the main crop preceding the CC had significant legacy effects on the AMF colonization of endive, however the legacy effects of the CC treatments were not affected by the identity of the preceding main crop.

\subsubsection{Effects of cover crops on AMF colonization in succeeding main crops}

Overall the CC treatments ryegrass and the mixture of ryegrass+clover resulted in a substantial increased AMF colonization in the roots of the subsequent 
grain (almost doubling) and vegetable (threefold increase) crops compared with winter fallow, and compared with most other CC. The good AMF host properties of a variety of grasses used as CC have been reported in previous field experiments. For example, wheat (Boswell et al., 1998; Kabir and Koide, 2000), rye (White and Weil, 2010)), oats (Kabir and Koide, 2002) and barley (García-González et al., 2016b) enhanced AMF compared with fallow. Our results are also in agreement with other studies (Lehman et al., 2012) showing more benefits from grasses to promote AMF in comparison with other mycorrhizal CC.

In contrast to our expectation, the legacy of the legume monocultures (white clover and common vetch) did not result in increased levels of AMF colonization compared with fallow. Only in oat roots the AMF colonization was relatively high after the clover CC treatment, mainly because of the arbuscules being significantly more abundant after clover than after radish or radish+vetch, but not significantly larger than after fallow. These results are in contrast to the findings of Deguchi et al. (2007) with white clover and of Njeru et al. (2014) with hairy vetch, since these legume $\mathrm{CC}$ in both experiments resulted in the highest AMF colonization in subsequently grown maize compared with fallow and with other CC treatments (but note grasses were not included). Moreover, in our experiment clover (and also vetch) monoculture resulted in much lower levels of AMF colonization than ryegrass monoculture. This result was surprising because white clover has been reported to be highly mycotrophic in comparison with ryegrass in a glasshouse experiment (Zhu et al., 2000). In our case, the lack of improvement in AMF colonization after the legume species may be due to the sensitivity of these crops to short days and cold leading to reduced growth (Ramírez-García et al., 2015). This, together with the vetch dieback after the first frost in December may have resulted in a reduction of AMF inoculum potential as compared with the more winter-hardy ryegrass. In addition, the expected greater root length density in grass in comparison with legume (Ramirez-Garcia et al., 2014) might have provided a larger source of inoculum from grass roots than from legume roots for AMF colonization in the subsequent crop. 
The combination of ryegrass+white clover increased the AMF colonization in endive and oat roots compared with fallow, despite the fact that in the mixture ryegrass was sown at only half the density of its monoculture. Similar to these results Lehman et al. (2012) found that a mixture oats+vetch did not differ from oats in monoculture and were better than vetch in monoculture with respect to the number of AMF propagules and the AMF biomass found in soil during these crop treatments. These findings may be explained by the idea that a good AMF host can improve the colonization of other plant species in the mixture through, for example, a higher fungal spore density (Chen et al., 2005). Moreover also the rooting patterns can change and root biomass can be increased when species are grown in mixture, as has for example been shown for barley and vetch (RamirezGarcia et al., 2014). Our results suggest that treatments with mixtures of grass(es) and legume(s) will maintain good degree of AMF colonization in the subsequent crop, with the benefit of combining the general advantages of both CC species, that is: the high production of biomass, weed control, the retention of nitrogen through immobilization in plant community biomass and the extra $\mathrm{N}$-input in soil through increased N-fixation by the legumes (Hartwig and Ammon, 2002).

The legacy of the radish and radish+vetch CC treatments did not reduce AMF colonization in the subsequent endive crop compared with fallow, yet importantly these treatments with radish resulted in a significant reduction in AMF colonization in oat roots. Our results for endive are in line with field experiments where no differences on AMF colonization in maize roots were found in comparison with fallow soil after cover cropping with Indian mustard (Njeru et al., 2014), forage radish (White and Weil, 2010) or sugar beet (Ocampo and Hayman, 1981). As suggested by White and Weil (2010), the lack of differences between radish and fallow for AMF colonization in endive might indicate that the period of radish growth as $\mathrm{CC}$ was not long enough to consolidate the antifungal effects. However, as we found significant lower AMF colonization in the oat roots after radish CC treatments we suggest that the radish grew long enough to cause effects. An explanation for the different responses in endive and oats may be the time of planting because oats were sown relatively soon after the incorporation of the CC into the soil, whereas the young endive plants were planted seven weeks after 
seeding the oats. The incorporation and decomposition of the radish (and other Brassicaceae) can generate a flush release of ITC compounds which can delay AMF colonization and the formation of arbuscules (Gavito and Miller, 1998), which may have been the case in the oats. Over time the ITC compounds disappear through volatilization and microbial decomposition of the ITC (Matthiessen and Shackleton, 2005), that way allowing the revival of the AMF inoculum, which may have happened for endive.

The potential of mixing of Brassicaceae CC species with AMF host species to promote AMF colonization in the following main crop through legacy effects has hardly been studied, despite the potential multiple benefits of combining two or more CC and the importance of Brassicaceae species as CC. In our study, the mixture of radish with common vetch as an AMF host CC failed to increase the AMF colonization in the subsequent crop. Probably, the absence of the expected AMF promoting effects of vetch can at least in part explain why the radish+vetch mixture did not improve AMF colonization as compared to radish in monoculture. Moreover, in mixtures of legumes with Brassicaceae species the fast growing of Brassicaceae tend to be promoted at the expense of the legume species due to competitive interactions (Wortman et al., 2012) such that other seeding proportions than 50/50 may be required for optimizing benefits of species in mixtures. Given our findings for ryegrass as a promotor of AMF colonization in subsequent crops, combining radish with ryegrass might have been a better combination in order to ameliorate suppressive effects of radish on AMF colonization in oat roots. However, White and Weil (2010), who assessed monocultures and mixtures of fodder radish with a good AMF host grass like rye, did not find more AMF colonization in the roots of the subsequent maize crop after rye-radish mixture as compared with radish monoculture and fallow. They attribute this finding to the possibility that the ITC released by the Brassicaceae affected the ability of rye to host AMF when both species were growing together. In the same line, Lehman et al. (2012) found that the number of AMF propagules in soil of mixtures of oats+canola did not differ from canola in monoculture and fallow, with values much lower than that of oat in monoculture. In contrast, their results were very different for the mixture oats+canola+vetch which showed 
values of AMF propagules as high as sole oat. Together these results demonstrate that mixtures have some potential to act in a complementing way with respect to AMF inoculum potential but that these effects remain hard to predict and warrant further research. In our conditions, we suggest to assess the option of combining radish with ryegrass, which acted as the best monoculture AMF host in our study. Moreover apart from \%AMF colonization studies on the AMF species identity of the species in the roots will also be very valuable so that host selectivity can be quantified and considered in crop and cover crop selection (Turrini et al., 2016).

\subsubsection{Effects of main crop prior to cover crops on AMF colonization in succeeding main crop}

In our 2-year experiment, the summer crop in 2014 significantly affected the AMF colonization in endive grown in the following year. AMF colonization of endive roots was increased in treatments with previous oats cultivation compared to treatments with an endive history. Oat roots showed similar levels of AMF colonization regardless of the identity of the preceding main crop. These results indicate that legacy effects can indeed remain in soil irrespective of the type of subsequent CC, however these effects appear to depend not only on the crop that leaves the legacy but also on the responding crop. These results are in line with Koide and Peoples (2012) who showed that wheat used as a winter CC was not able to remove the negative effect of the preceding Brassicaceae main crop on the subsequent main crop maize grown after the winter CC. Our observed differences between the oat and endive crops may be due to different growing timespans as in the first cropping year endive was harvested a month earlier than oats, such that endive plots remained bare for one month before the CC treatments were started. Moreover, the AMF density in the soil might have been larger in former oat plots than in former endive plots not only because of the longer presence on the field but also because of the difference in root density with the fibrous root system of the oat and the taproot system in endive, although species with a taproot system tend to be more responsive to AMF (Yang et al., 2015). The reason why we did not find effects of the previous main crop in oats may be due to the fact that in the oat roots the differences of the preceding crop disappeared during the longer growing 
period (90 days) as compared with endive (41 days). Our results support the idea that the variation of main crop apart from differences in CC, can be a crucial factor for the AMF abundance in agroecosystems (Miranda et al., 2005), and that length of the growing season might be an important crop parameter to take into account.

\subsection{CONCLUSIONS}

The choice of cover crop species and species mixture can have large effects on AMF colonization in the following grain or vegetable crop and also the main crop preceding the cover crop can leave long-lasting legacy effects on AMF for the following main crop. Ryegrass and the mixture ryegrass+clover as cover crop stimulated the AMF colonization in the subsequent crop, whereas radish and the mixture of radish+vetch had a suppressive effect in the subsequent oat crop. Combining the non-host radish with the AMF host vetch failed to counterbalance the negative effect of the Brassicaceae species on AMF. Overall suppression of AMF by Brassicaceae may not be easily offset by cover crop mixtures, yet cover crop combinations with grass species appear promising to promote AMF colonization in subsequent crops. 



\section{GENERAL CONCLUSIONS}

The biochemical and biological indicators studied throughout the long-term experiment enhanced by CC used under Mediterranean conditions. In general, both CC, barley and vetch increased the $\mathrm{C}_{\text {mic }}$ and enzymatic activities such as $\beta$ glucosidase, $\beta$-glucosaminidase, dehydrogenase and arylsulphatase, while only the vetch treatment showed greater urease and alkaline phosphatase activities. The $\beta$ glucosaminidase and dehydrogenase activities responded earlier than the other enzymes (four years after the onset of the experiment). The easily extractable and total glomalin fractions enhanced by both CC from 2008, so they might be considered one of the most sensitive parameters under our field conditions. In contrast, TOC content and $\mathrm{C}_{\text {mic }}$ responded to CC introduction only after the sixth year of the experiment. While TOC levels kept increasing during the ten years of crop rotation, $\mathrm{C}_{\text {mic }}$ maintained relatively constant. The presence of $\mathrm{CC}$ residues on the soil surface and the implantation of minimum tillage stimulated the microbial activity particularly in the $0-5 \mathrm{~cm}$ layer. Despite the 10 years elapsed since the beginning of the trial, most improvements did not reach deeper layers (at least in the first $20 \mathrm{~cm}$ depth of the soil).

Replacing winter fallow with cover crops in an irrigated Mediterranean cropping system had overall benefits on the AMF activity. Both directly related AMF variables, (mycorrhizal colonization, length of hyphae and AMF spores) as well as indirectly related ones (EE-GRSP and $\beta$-glucosaminidase activity) improved in the subsequent sunflower and maize crops (sixth and seventh years). The EEGRSP was able to maintain strong and positive correlations with all the variables directly related to $\mathrm{AMF}$, so that we propose it as an easy AMF indicator to be evaluated with the rest of AMF variables. Mycorrhizal colonization was the AMF parameter more affected by the sampling date, so it should be combined with the measurement of the other AMF parameters (length of hyphae, AMF spores and glomalin content) that better maintained differences between treatments over time. 
The studies under different climatic and soil conditions showed some matching results regarding the choice of the CC species. Thus, grasses CC such as barley or ryegrass stimulated mycorrhization in the subsequent main crops (sunflower, maize, oat or endives) whereas the legumes CC (vetch, clover) showed no differences with respect to fallow. When we incorporated a legume in a mixture with grass (ryegrass + clover), it did not provide any advantage regarding AMF stimulation but the percentage of colonization was not significantly decreased. Therefore, the symbiosis between Rhizobium and legume did not show any positive effect on AMF activity in either climate area. Type of main crop also should be considered when assessing CC effects on AMF. Thus, the use of Brassicaceae species like radish as CC during the winter period affected the mycorrhizal colonization negatively in the subsequent oat crop whereas endive crop was not affected. This fact confirms possible suppressive effects due to the antifungal substances from Brassicaceae species. The combination with a legume (radish+vetch) did not counterbalance this negative legacy on AMF.

The higher WSA after barley CC and its correlations with the AMF propagules (length of hyphae and AMF spores) confirmed the important role of CC in AMF stimulation and, as consequence, an improvement of soil stability. The enzymatic activities ( $\beta$-glucosaminidase and alkaline phosphatase enzymes) and nutritional parameters were affected by the CC treatments (eighth year). The $\mathrm{N}$ fixation of legumes permitted that vetch increased shoot $\mathrm{N}$ in maize plants, whereas barley treatment only improved shoot P. The nutritional parameters were affected by cover cropping only in the early maize growth stages since treatments differences vanished from the sixth week on after maize sowing. During the maize growth, CC increased maize height respect to fallow, but no CC effect was obtained at harvest. Therefore, the main benefits of introducing CC were related to an enhancement of soil quality and nutrient supply rather than to an increased yield of the following maize crop.

As a final conclusion, the effect of CC use during winter period in the cropping system had overall benefits on the AMF activity. Grass CC was the treatment that increased most of the AMF parameters with respect to the fallow resulting to an improvement of soil stability. In addition, the positive relationships between AMF 
activity and shoot $\mathrm{P}$ concentrations confirmed the good AMF-root-plant interaction in the early stages of maize, although effects disappeared with the passing of the time and did not have any influence in the final yield. The evolution of soil parameters during the long-term experiment showed that the microbial activity responses to CC introduction were relatively rapid whereas the build of SOM was slower. Fallow treatment also showed improvements in soil parameters due to the switch from conventional to minimum tillage. Therefore, the combined action of fallow replacement by CC and tillage reduction could solve or at least reduced the negative impacts of cropping systems intensification, such as low SOM content, poor soil aggregation or reduced microbial activity, leading to a final improvement of the soil quality. 



\section{REFERENCES}

Abawi, G., Widmer, T., 2000. Impact of soil health management practices on soilborne pathogens, nematodes and root diseases of vegetable crops. Appl Soil Ecol 15, 37-47.

Acosta-Martinez, V., Zobeck, T., Gill, T., Kennedy, A., 2003. Enzyme activities and microbial community structure in semiarid agricultural soils. Biol Fert Soils 38, 216-227.

Acosta-Martinez, V., Zobeck, T.M., Allen, V., 2004. Soil microbial, chemical and physical properties in continuous cotton and integrated crop-livestock systems. Soil Sci Soc Am J 68, 1875-1884.

Acosta-Martinez, V., Mikha, M.M., Vigil, M.F., 2007. Microbial communities and enzyme activities in soils under alternative crop rotations compared to wheat-fallow for the Central Great Plains. Appl Soil Ecol 37, 41-52.

Acosta-Martínez, V., Lascano, R., Calderón, F., Booker, J.D., Zobeck, T.M., Upchurch, D.R., 2011. Dryland cropping systems influence the microbial biomass and enzyme activities in a semiarid sandy soil. Biol Fert Soils 47, 655-667.

Ajwa, H., Dell, C., Rice, C., 1999. Changes in enzyme activities and microbial biomass of tallgrass prairie soil as related to burning and nitrogen fertilization. Soil Biol Biochem 31, 769-777.

Alguacil, M.M., Torrecillas, E., García-Orenes, F., Roldán, A., 2014. Changes in the composition and diversity of AMF communities mediated by management practices in a Mediterranean soil are related with increases in soil biological activity. Soil Biol Biochem 76, 34-44.

Alkorta, I., Aizpurua, A., Riga, P., Albizu, I., Amezaga, I., Garbisu, C., 2003. Soil enzyme activities as biological indicators of soil health. Reviews on environmental health 18, 65-73.

Alonso-Ayuso, M., Gabriel, J.L., Quemada, M., 2014. The kill date as a management tool for cover cropping success. PloS One 9, e109587.

Alvarez, C.R., Alvarez, R., 2000. Short-term effects of tillage systems on active soil microbial biomass. Biol Fert Soils 31, 157-161.

Allen, R.G., Pereira, L.S., Raes, D., Smith, M., 1998. FAO 56 Irrigation and drainage paper: crop evapotranspiration. Rome: Food and Agriculture Organization of the United Nations, 26-40.

Anderson, J., Domsch, K., 1978. A physiological method for the quantitative measurement of microbial biomass in soils. Soil Biol Biochem 10, 215-221.

Andersson, M., Kjøller, A., Struwe, S., 2004. Microbial enzyme activities in leaf litter, humus and mineral soil layers of European forests. Soil Biol Biochem 36, 1527-1537. 
Artursson, V., Finlay, R.D., Jansson, J.K., 2006. Interactions between arbuscular mycorrhizal fungi and bacteria and their potential for stimulating plant growth. Environ Microbiol 8, 1-10.

Azcón-Aguilar, C., Barea, J.M., 1995. Saprophytic growth of arbuscular mycorrhizal fungi. Springer Berlin Heidelberg, pp. 391-407.

Azcón-Aguilar, C., Barea, J.M., 1997. Arbuscular mycorrhizas and biological control of soil-borne plant pathogens-an overview of the mechanisms involved. Mycorrhiza 6, 457-464.

Bai, C., He, X., Tang, H., Shan, B., Zhao, L., 2009. Spatial distribution of arbuscular mycorrhizal fungi, glomalin and soil enzymes under the canopy of Astragalus adsurgens Pall. in the Mu Us sandland, China. Soil Biol Biochem 41, 941-947.

Balezentiene, L., Klimas, E., 2009. Effect of organic and mineral fertilizers and land management on soil enzyme activities. Agron Res 7, 191-197.

Balota, E.L., Kanashiro, M., Colozzi Filho, A., Andrade, D.S., Dick, R.P., 2004. Soil enzyme activities under long-term tillage and crop rotation systems in subtropical agro-ecosystems. Braz J Microbiol 35, 300-306.

Balota, E.L., Calegari, A., Nakatani, A.S., Coyne, M.S., 2014a. Benefits of winter cover crops and no-tillage for microbial parameters in a Brazilian Oxisol: A longterm study. Agr Ecosyst Environ 197, 31-40.

Balota, E.L., Machineski, O., Honda, C., Yada, I.F.U., Barbosa, G., Nakatani, A.S., Coyne, M.S., 2014b. Response of arbuscular mycorrhizal fungi in different soil tillage systems to long- term swine slurry application. Land Degrad Dev.

Bandick, A.K., Dick, R.P., 1999. Field management effects on soil enzyme activities. Soil Biol Biochem 31, 1471-1479.

Barea, J.M., Palenzuela, J., Cornejo, P., Sánchez-Castro, I., Navarro-Fernández, C., Lopéz-García, A., Estrada, B., Azcón, R., Ferrol, N., Azcón-Aguilar, C., 2011. Ecological and functional roles of mycorrhizas in semi-arid ecosystems of Southeast Spain. J Arid Environ 75, 1292-1301.

Beare, M., Hendrix, P., Coleman, D., 1994. Water-stable aggregates and organic matter fractions in conventional-and no-tillage soils. Soil Sci Soc Am J 58, 777-786.

Bedini, S., Avio, L., Argese, E., Giovannetti, M., 2007. Effects of long-term land use on arbuscular mycorrhizal fungi and glomalin-related soil protein. Agr Ecosyst Environ 120, 463-466.

Bedini, S., Pellegrino, E., Avio, L., Pellegrini, S., Bazzoffi, P., Argese, E., Giovannetti, M., 2009. Changes in soil aggregation and glomalin-related soil protein content as affected by the arbuscular mycorrhizal fungal species Glomus mosseae and Glomus intraradices. Soil Biol Biochem 41, 1491-1496.

Bedini, S., Avio, L., Sbrana, C., Turrini, A., Migliorini, P., Vazzana, C., Giovannetti, M., 2013. Mycorrhizal activity and diversity in a long-term organic Mediterranean agroecosystem. Biol Fert Soils 49, 781-790. 
Bienes, R., Marqués, M.J., Ruíz, M., 2012. Cultivos herbáceos, viñedos y olivares: el manejo tradicional del suelo y sus consecuencias en la erosión hídrica. Cuadernos de Investigación Geográfica, 49-74.

Boswell, E.P., Koide, R.T., Shumway, D.L., Addy, H.D., 1998. Winter wheat cover cropping, VA mycorrhizal fungi and maize growth and yield. Agr Ecosyst Environ 67, 55-65.

Bowles, T.M., Jackson, L.E., Loeher, M., Cavagnaro, T.R., 2016. Ecological intensification and arbuscular mycorrhizas: a meta-analysis of tillage and cover crop effects. J Appl Ecol.

Bowman, G., Shirley, C., C., C., 2000. Benefits of cover crops. In: Managing cover crops profitably. 2nd ed. USDA Sustainable Agrilculture Network, Beltsville, MD, 9-11.

Bronick, C.J., Lal, R., 2005. Soil structure and management: a review. Geoderma 124, 3-22.

Buyer, J.S., Teasdale, J.R., Roberts, D.P., Zasada, I.A., Maul, J.E., 2010. Factors affecting soil microbial community structure in tomato cropping systems. Soil Biol Biochem 42, 831-841.

Caravaca, F., Masciandaro, G., Ceccanti, B., 2002. Land use in relation to soil chemical and biochemical properties in a semiarid Mediterranean environment. Soil Till Res 68, 23-30.

Caravaca, F., Alguacil, M., Azcón, R., Roldán, A., 2006. Formation of stable aggregates in rhizosphere soil of Juniperus oxycedrus: Effect of AM fungi and organic amendments. Appl Soil Ecol 33, 30-38.

Carter, M., Gregorich, E., Angers, D., Beare, M., Sparling, G., Wardle, D., Voroney, R., 1999. Interpretation of microbial biomass measurements for soil quality assessment in humid temperate regions. Can J Soil Sci 79, 507-520.

Cavigelli, M.A., Thien, S.J., 2003. Phosphorus bioavailability following incorporation of green manure crops. Soil Sci Soc Am J 67, 1186-1194.

Clark, A., 2008. Managing cover crops profitably. DIANE Publishing, Beltsville, MD.

Cox, G., Tinker, P., 1976. Translocation and transfer of nutrients in vesiculararbuscular mycorrhizas. I. The arbuscule and phosphorus transfer: a quantitative ultrastructural study. New Phytol, 371-378.

Chavarría, D.N., Verdenelli, R.A., Serri, D.L., Restovich, S.B., Andriulo, A.E., Meriles, J.M., Vargas-Gil, S., 2016. Effect of cover crops on microbial community structure and related enzyme activities and macronutrient availability. Eur J Soil Biol 76, 74-82.

Chen, X., Tang, J., Zhi, G., Hu, S., 2005. Arbuscular mycorrhizal colonization and phosphorus acquisition of plants: effects of coexisting plant species. Appl Soil Ecol 28, 259-269.

Dabney, S.M., Delgado, J.A., Reeves, D.W., 2001. Using winter cover crops to improve soil and water quality. Commun Soil Sci Plan 32, 1221-1250. 
Das, S.K., Varma, A., 2010. Role of enzymes in maintaining soil health, Soil enzymology. Springer, pp. 25-42.

De la Horra, A., Conti, M., Palma, R., 2003. $\beta$-Glucosidase and Proteases Activities as Affected by Long-Term Management Practices in a Typic Argiudoll Soil. Commun Soil Sci Plan 34, 2395-2404.

Declerck, S., D'or, D., Cranenbrouck, S., Boulengé, L.E., 2001. Modelling the sporulation dynamics of arbuscular mycorrhizal fungi in monoxenic culture. Mycorrhiza 11, 225-230.

DeForest, J.L., Noormets, A., McNulty, S.G., Sun, G., Tenney, G., Chen, J., 2006. Phenophases alter the soil respiration-temperature relationship in an oakdominated forest. Inter J Biometeorol 51, 135-144.

Deguchi, S., Shimazaki, Y., Uozumi, S., Tawaraya, K., Kawamoto, H., Tanaka, O., 2007. White clover living mulch increases the yield of silage corn via arbuscular mycorrhizal fungus colonization. Plant Soil 291, 291-299.

Dick, R., Myrold, D., Kerle, E., 1988. Microbial biomass and soil enzyme activities in compacted and rehabilitated skid trail soils. Soil Sci Soc Am J 52, 512-516.

Dick, R., 1997. Soil enzyme activities as integrative indicators of soil health.

Dick, W., Tabatabai, M.A., 1993. Significance and potential uses of soil enzymes. Soil microbial ecology: application in agricultural and environmental management. Marcel Dekker, New York, 95-125.

Ding, G., Liu, X., Herbert, S., Novak, J., Amarasiriwardena, D., Xing, B., 2006. Effect of cover crop management on soil organic matter. Geoderma 130, 229-239.

Driver, J.D., Holben, W.E., Rillig, M.C., 2005. Characterization of glomalin as a hyphal wall component of arbuscular mycorrhizal fungi. Soil Biol Biochem 37, 101106.

Eivazi, F., Bayan, M., Schmidt, K., 2003. Select soil enzyme activities in the historic Sanborn Field as affected by long-term cropping systems. Commun Soil Sci Plan 34, 2259-2275.

Ekenler, M., Tabatabai, M.A., 2003. Tillage and residue management effects on $\beta$ glucosaminidase activity in soils. Soil Biol Biochem 35, 871-874.

El-Hassanin, A., Lynd, J., 1985. Soil fertility effects with tripartite symbiosis for growth, nodulation and nitrogenase activity of Vicia faba L. J Plant Nutr 8, 491-504.

Elliott, E., 1994. The potential use of soil biotic activity as an indicator of productivity, sustainability and pollution. Soil biota: Management in sustainable farming systems. CSIRO Publishing: Melbourne, pp. 250-256.

Fahey, J.W., Zalcmann, A.T., Talalay, P., 2001. The chemical diversity and distribution of glucosinolates and isothiocyanates among plants. Phytochemistry 56, 5-51. 
Filion, M., St-Arnaud, M., Fortin, J., 1999. Direct interaction between the arbuscular mycorrhizal fungus Glomus intraradices and different rhizosphere microorganisms. New Phytol 141, 525-533.

Frankenberger, W., Dick, W., 1983. Relationships between enzyme activities and microbial growth and activity indices in soil. Soil Sci Soc Am J 47, 945-951.

Frey-Klett, P., Garbaye, J.a., Tarkka, M., 2007. The mycorrhiza helper bacteria revisited. New Phytol 176, 22-36.

Frye, W., Blevins, R., Smith, M., Corak, S., Varco, J., 1988. Role of annual legume cover crops in efficient use of water and nitrogen. Cropping strategies for efficient use of water and nitrogen, 129-154.

Gabriel, J., Alonso-Ayuso, M., García-González, I., Hontoria, C., Quemada, M., 2016. Nitrogen use efficiency and fertiliser fate in a long-term experiment with winter cover crops. Eur J Agron 79, 14-22.

Gabriel, J.L., Lizaso, J.I., Quemada, M., 2010. Laboratory versus field calibration of capacitance probes. Soil Sci Soc Am J 74, 593-601.

Gabriel, J.L., Quemada, M., 2011. Replacing bare fallow with cover crops in a maize cropping system: yield, N uptake and fertiliser fate. Eur J Agron 34, 133-143.

Gabriel, J.L., Muñoz-Carpena, R., Quemada, M., 2012. The role of cover crops in irrigated systems: Water balance, nitrate leaching and soil mineral nitrogen accumulation. Agr Ecosyst Environ 155, 50-61.

Gabriel, J.L., Garrido, A., Quemada, M., 2013. Cover crops effect on farm benefits and nitrate leaching: Linking economic and environmental analysis. Agr Syst 121, 23-32.

Galvez, L., Douds, D.D., Wagoner, P., Longnecker, L.R., Drinkwater, L.E., Janke, R.R., 1995. An overwintering cover crop increases inoculum of VAM fungi in agricultural soil. Am J Alternative Agr 10, 152-156.

Galvez, L., Douds, D., Drinkwater, L., Wagoner, P., 2001. Effect of tillage and farming system upon VAM fungus populations and mycorrhizas and nutrient uptake of maize. Plant Soil 228, 299-308.

García-González, I., Gabriel, J.L., Alonso-Ayuso, M., Quemada, M., Hontoria, C., 2016a. Effect of cover crops in enzymatic activities and other biological parameters related to soil quality. VII Congresso Ibérico das Ciências do Solo (CICS 2016) and VI Congresso Nacional de Rega e Drenagem, Berja (Portugal).

García-González, I., Quemada, M., Gabriel, J.L., Hontoria, C., 2016b. Arbuscular mycorrhizal fungal activity responses to winter cover crops in a sunflower and maize cropping system. Appl Soil Ecol 102, 10-18.

García-Izquierdo, C., 2003. Técnicas de análisis de parámetros bioquímicos en suelos: medida de actividades enzimáticas y biomasa microbiana. MundiPrensa, Madrid, p. 371. 
Garcia, C., Hernandez, T., Roldan, A., Albaladejo, J., 1997. Biological and biochemical quality of a semiarid soil after induced devegetation. Journal of Environmental Quality 26, 1116-1122.

García, C., Hernández, T., Costa, F., Ceccanti, B., Masciandaro, G., 1993. The dehydrogenase activity of soil as an ecological marker in processes of perturbed system regeneration, XI International Symposium Environmental Biogeochemistry, Salamanca, Spain, pp. 89-100.

Gavito, M.E., Miller, M.H., 1998. Changes in mycorrhiza development in maize induced by crop management practices. Plant Soil 198, 185-192.

Geisseler, D., Horwath, W.R., 2009. Relationship between carbon and nitrogen availability and extracellular enzyme activities in soil. Pedobiologia 53, 8798.

George, E., Marschner, H., Jakobsen, I., 1995. Role of arbuscular mycorrhizal fungi in uptake of phosphorus and nitrogen from soil. Crit Rev Biotechnol 15, 257 270.

Gianinazzi, S., Gollotte, A., Binet, M.-N., van Tuinen, D., Redecker, D., Wipf, D., 2010. Agroecology: the key role of arbuscular mycorrhizas in ecosystem services. Mycorrhiza 20, 519-530.

Gil-Sotres, F., Trasar-Cepeda, C., Leirós, M., Seoane, S., 2005. Different approaches to evaluating soil quality using biochemical properties. Soil Biol Biochem 37, 877-887.

Giovannetti, M., Mosse, B., 1980. An evaluation of techniques for measuring vesicular arbuscular mycorrhizal infection in roots. New Phytol 84, 489-500.

Giovannetti, M., Sbrana, C., 1998. Meeting a non-host: the behaviour of AM fungi. Mycorrhiza 8, 123-130.

Gonzalez-Quiñones, V., Stockdale, E., Banning, N., Hoyle, F., Sawada, Y., Wherrett, A., Jones, D., Murphy, D., 2011. Soil microbial biomass-interpretation and consideration for soil monitoring. Soil Res 49, 287-304.

Greenwood, D., Lemaire, G., Gosse, G., Cruz, P., Draycott, A., Neeteson, J., 1990. Decline in percentage N of C3 and C4 crops with increasing plant mass. Ann Bot-London 66, 425-436.

Hai-Ming, T., Xiao-Ping, X., Wen-Guang, T., Ye-Chun, L., Ke, W., Guang-Li, Y., 2014. Effects of Winter Cover Crops Residue Returning on Soil Enzyme Activities and Soil Microbial Community in Double-Cropping Rice Fields.

Haider, K.R., 2014. The Effect of Cropping Rotation and Management on Arbuscular Mycorrhizal Fungi in a Sustainable Dairy Cropping System. Doctoral Dissertation,The Pennsylvania State University, PN.

Harinikumar, K., Bagyaraj, D., 1988. Effect of crop rotation on native vesicular arbuscular mycorrhizal propagules in soil. Plant Soil 110, 77-80.

Hartwig, N.L., Ammon, H.U., 2002. Cover crops and living mulches. Weed Sci 50, 688-699. 
Haynes, R., Francis, G., 1993. Changes in microbial biomass C, soil carbohydrate composition and aggregate stability induced by growth of selected crop and forage species under field conditions. Eur J Soil Sci 44, 665-675.

Higo, M., Isobe, K., Yamaguchi, M., Drijber, R.A., Jeske, E.S., Ishii, R., 2013. Diversity and vertical distribution of indigenous arbuscular mycorrhizal fungi under two soybean rotational systems. Biol Fert Soils 49, 1085-1096.

Higo, M., Isobe, K., Drijber, R.A., Kondo, T., Yamaguchi, M., Takeyama, S., Suzuki, Y., Niijima, D., Matsuda, Y., Ishii, R., 2014. Impact of a 5-year winter cover crop rotational system on the molecular diversity of arbuscular mycorrhizal fungi colonizing roots of subsequent soybean. Biol Fert Soils 50, 913-926.

Higo, M., Isobe, K., Matsuda, Y., Ichida, M., Torigoe, Y., 2015. Influence of Sowing Season and Host Crop Identity on the Community Structure of Arbuscular Mycorrhizal Fungi Colonizing Roots of Two Different Gramineous and Leguminous Crop Species. Adv Microb 5, 107-116.

Holford, I., 1997. Soil phosphorus: its measurement, and its uptake by plants. Soil Research 35, 227-240.

Ibijbijen, J., Urquiaga, S., Ismaili, M., Alves, B., Boddey, R., 1996. Effect of arbuscular mycorrhizal fungi on growth, mineral nutrition and nitrogen fixation of three varieties of common beans (Phaseolus vulgaris). New Phytol 134, 353-360.

Isobe, K., Higo, M., Kondo, T., Sato, N., Takeyama, S., Torigoe, Y., 2014. Effect of winter crop species on arbuscular mycorrhizal fungal colonization and subsequent soybean yields. Plant Prod Sci 17, 260-267.

Jakobsen, I., Abbott, L.K., Robson, A.D., 1992. External hyphae of vesiculararbuscular mycorrhizal fungi associated with Trifolium subterraneum L. New Phytol 120, 371-380.

Jeffries, P., Gianinazzi, S., Perotto, S., Turnau, K., Barea, J.-M., 2003. The contribution of arbuscular mycorrhizal fungi in sustainable maintenance of plant health and soil fertility. Biol Fert Soils 37, 1-16.

Jin, H., Pfeffer, P., Douds, D., Piotrowski, E., Lammers, P., Shachar-Hill, Y., 2005. The uptake, metabolism, transport and transfer of nitrogen in an arbuscular mycorrhizal symbiosis. New Phytol 168, 687-696.

Joner, E.J., Jakobsen, I., 1995. Growth and extracellular phosphatase activity of arbuscular mycorrhizal hyphae as influenced by soil organic matter. Soil Biol Biochem 27, 1153-1159.

Kabir, Z., O'halloran, I.P., Fyles, J.W., Hamel, C., 1997. Seasonal changes of arbuscular mycorrhizal fungi as affected by tillage practices and fertilization: hyphal density and mycorrhizal root colonization. Plant Soil 192, 285-293.

Kabir, Z., Koide, R.T., 2000. The effect of dandelion or a cover crop on mycorrhiza inoculum potential, soil aggregation and yield of maize. Agr Ecosyst Environ 78, 167-174. 
Kabir, Z., Koide, R.T., 2002. Effect of autumn and winter mycorrhizal cover crops on soil properties, nutrient uptake and yield of sweet corn in Pennsylvania, USA. Plant Soil 238, 205-215.

Kabir, Z., 2005. Tillage or no-tillage: impact on mycorrhizae. Can J Plant Sci 85.

Kamprath, E., Von Chandler, W., Krantz, B.A., 1958. Winter cover crops: Their effects on corn yields and soil properties. N C Agr Exp Sta.

Kandeler, E., Stemmer, M., Klimanek, E.-M., 1999. Response of soil microbial biomass, urease and xylanase within particle size fractions to long-term soil management. Soil Biology and Biochemistry 31, 261-273.

Karasawa, T., Kasahara, Y., Takebe, M., 2001. Variable response of growth and arbuscular mycorrhizal colonization of maize plants to preceding crops in various types of soils. Biol Fert Soils 33, 286-293.

Kaye, J.P., Quemada, M., 2017. Using cover crops to mitigate and adapt to climate change. A review. Agron Sustain Dev 37, 4.

Kemper, W.D., Rosenau, R.C., 1986. Aggregate Stability and Size Distribution. Methods of Soil Analysis: Part 1. Physical and Mineralogical Methods Agronomy Monograph no. 9 (2dn Edition), Madison, WI, 425-442.

Koerselman, W., Meuleman, A.F., 1996. The vegetation N: P ratio: a new tool to detect the nature of nutrient limitation. J Appl Ecol, 1441-1450.

Koide, R.T., Peoples, M.S., 2012. On the nature of temporary yield loss in maize following canola. Plant Soil 360, 259-269.

Köppen, W., 1900. Versuch einer Klassifikation der Klimate, vorzugsweise nach ihren Beziehungen zur Pflanzenwelt. Geogr Z 6, 593-611.

Kruidhof, H., Bastiaans, L., Kropff, M., 2008. Ecological weed management by cover cropping: effects on weed growth in autumn and weed establishment in spring. Weed Res 48, 492-502.

Kuo, S., Sainju, U.M., Jellum, E.J., 1997. Winter cover crop effects on soil organic carbon and carbohydrate in soil. Soil Sci Soc Am J 61, 145-152.

Lagomarsino, A., Moscatelli, M.C., Tizio, A.D., Mancinelli, R., Grego, S., Marinari, S., 2009. Soil biochemical indicators as a tool to assess the short-term impact of agricultural management on changes in organic $\mathrm{C}$ in a Mediterranean environment. Ecol Indic 9, 518-527.

Lal, R., Hall, G., Miller, F., 1989. Soil degradation: I. Basic processes. Land Degrad Dev 1, 51-69.

Lammerding, D.M., Hontoria, C., Tenorio, J.L., Walter, I., 2011. Mediterranean dryland farming: effect of tillage practices on selected soil properties. Agron J 103, 382-389.

Lancashire, P.D., Bleiholder, H., Boom, T., Langelüddeke, P., Stauss, R., Weber, E., Witzenberger, A., 1991. A uniform decimal code for growth stages of crops and weeds. Ann Appl Biol 119, 561-601. 
Lascano, R.J., Krieg, D.R., Baker, J.T., Goebel, T.S., Gitz III, D.C., 2015. Planting Cotton in a Crop Residue in a Semiarid Climate: Water Balance and Lint Yield. Open Journal of Soil Science 5, 236.

Lavin, M., Herendeen, P.S., Wojciechowski, M.F., 2005. Evolutionary rates analysis of Leguminosae implicates a rapid diversification of lineages during the Tertiary. Systematic biology 54, 575-594.

Lehman, R.M., Taheri, W.I., Osborne, S.L., Buyer, J.S., Jr., D.D.D., 2012. Fall cover cropping can increase arbuscular mycorrhizae in soils supporting intensive agricultural production. Appl Soil Ecol 61, 300-304.

Lekberg, Y., Koide, R.T., 2005. Arbuscular mycorrhizal fungi, rhizobia, available soil $\mathrm{P}$ and nodulation of groundnut (Arachis hypogaea) in Zimbabwe. Agr, Ecosyst Environ 110, 143-148.

Lekberg, Y., Koide, R., 2008. Effect of soil moisture and temperature during fallow on survival of contrasting isolates of arbuscular mycorrhizal fungi. Botany 86, 1117-1124.

Liu, A., Ma, B., Bomke, A., 2005. Effects of cover crops on soil aggregate stability, total organic carbon, and polysaccharides. Soil Sci Soc Am J 69, 2041-2048.

Lovelock, C.E., Wright, S.F., Clark, D.A., Ruess, R.W., 2004a. Soil stocks of glomalin produced by arbuscular mycorrhizal fungi across a tropical rain forest landscape. J Ecol 92, 278-287.

Lovelock, C.E., Wright, S.F., Nichols, K.A., 2004b. Using glomalin as an indicator for arbuscular mycorrhizal hyphal growth: an example from a tropical rain forest soil. Soil Biol Biochem 36, 1009-1012.

Lutgen, E.R., Muir-Clairmont, D., Graham, J., Rillig, M.C., 2003. Seasonality of arbuscular mycorrhizal hyphae and glomalin in a western Montana grassland. Plant Soil 257, 71-83.

Mancinelli, R., Marinari, S., Di Felice, V., Savin, M., Campiglia, E., 2013. Soil property, $\mathrm{CO}_{2}$ emission and aridity index as agroecological indicators to assess the mineralization of cover crop green manure in a Mediterranean environment. Ecol Indic 34, 31-40.

Marinari, S., Mancinelli, R., Campiglia, E., Grego, S., 2006. Chemical and biological indicators of soil quality in organic and conventional farming systems in Central Italy. Ecol Indic 6, 701-711.

Marschner, H., Dell, B., 1994. Nutrient uptake in mycorrhizal symbiosis. Plant Soil 159, 89-102.

Marschner, P., Baumann, K., 2003. Changes in bacterial community structure induced by mycorrhizal colonisation in split-root maize. Plant Soil 251, 279289.

Matthiessen, J.N., Shackleton, M.A., 2005. Biofumigation: environmental impacts on the biological activity of diverse pure and plant-derived isothiocyanates. Pest Manag Sci 61, 1043-1051. 
Mazzoncini, M., Sapkota, T.B., Bàrberi, P., Antichi, D., Risaliti, R., 2011. Long-term effect of tillage, nitrogen fertilization and cover crops on soil organic carbon and total nitrogen content. Soil Till Res 114, 165-174.

Mbuthia, L.W., Acosta-Martinez, V., DeBryun, J., Schaeffer, S., Tyler, D., Odoi, E., Mpheshea, M., Walker, F., Eash, N., 2015. Long term tillage, cover crop, and fertilization effects on microbial community structure, activity: Implications for soil quality. Soil Biol Biochem 89, 24-34.

McGonigle, T., Miller, M., Evans, D., Fairchild, G., Swan, J., 1990. A new method which gives an objective measure of colonization of roots by vesiculararbuscular mycorrhizal fungi. New Phytol, 495-501.

McGonigle, T.P., Miller, M.H., 1999. Winter survival of extraradical hyphae and spores of arbuscular mycorrhizal fungi in the field. Appl Soil Ecol 12, 41-50.

McGuire, A.M., 2003. Mustard green manures replace fumigant and improve infiltration in potato cropping system. Crop Manag 2, 0-0.

Melero, S., López-Garrido, R., Murillo, J.M., Moreno, F., 2009. Conservation tillage: Short-and long-term effects on soil carbon fractions and enzymatic activities under Mediterranean conditions. Soil Till Res 104, 292-298.

Mendes, I., Bandick, A., Dick, R., Bottomley, P., 1999. Microbial biomass and activities in soil aggregates affected by winter cover crops. Soil Sci Soc Am J 63, 873-881.

Miller, M., Palojarvi, A., Rangger, A., Reeslev, M., Kjoller, A., 1998. The use of fluorogenic substrates to measure fungal presence and activity in soil. Appl Environ Microbiol 64, 613-617.

Miller, R., Miller, S., Jastrow, J., Rivetta, C., 2002. Mycorrhizal mediated feedbacks influence net carbon gain and nutrient uptake in Andropogon gerardii. New Phytol 155, 149-162.

Miller, R.M., Jastrow, J.D., 2000. Mycorrhizal fungi influence soil structure. Springer Netherlands, pp. 3-18.

Miranda, J.C.C.D., Vilela, L., Miranda, L.N.D., 2005. Dynamics and contribution of arbuscular mycorrhiza in culture systems with crop rotation. Pesqui Agropecu Bras 40, 1005-1014.

Morton, J.B., Redecker, D., 2001. Two new families of Glomales, Archaeosporaceae and Paraglomaceae, with two new genera Archaeospora and Paraglomus, based on concordant molecular and morphological characters. Mycologia, 181-195.

Munkholm, L.J., Hansen, E.M., 2012. Catch crop biomass production, nitrogen uptake and root development under different tillage systems. Soil Use Manag 28, 517-529.

Muñoz, A., López-Piñeiro, A., Ramírez, M., 2007. Soil quality attributes of conservation management regimes in a semi-arid region of south western Spain. Soil Till Res 95, 255-265. 
Nannipieri, P., Giagnoni, L., Renella, G., Puglisi, E., Ceccanti, B., Masciandaro, G., Fornasier, F., Moscatelli, M.C., Marinari, S., 2012. Soil enzymology: classical and molecular approaches. Biol Fertil Soils 48, 743-762.

Ndiaye, E., Sandeno, J., McGrath, D., Dick, R., 2000. Integrative biological indicators for detecting change in soil quality. Am J Alternative Agr 15, 26-36.

Nelson, D.W., Sommers, L.E., 1996. Total carbon, organic carbon, and organic matter. Methods of soil analysis part 3-Chemical Methods. SSSA Book Series No. 5. Madison, WI, 961-1010.

Nivelle, E., Verzeaux, J., Habbib, H., Kuzyakov, Y., Decocq, G., Roger, D., Lacoux, J., Duclercq, J., Spicher, F., Nava-Saucedo, J.-E., 2016. Functional response of soil microbial communities to tillage, cover crops and nitrogen fertilization. Appl Soil Ecol 108, 147-155.

Njeru, E.M., Avio, L., Sbrana, C., Turrini, A., Bocci, G., Bàrberi, P., Giovannetti, M., 2014. First evidence for a major cover crop effect on arbuscular mycorrhizal fungi and organic maize growth. Agron Sustain Dev 34, 841-848.

Ocampo, J., Hayman, D., 1981. Influence of plant interactions on vesiculararbuscular mycorrhizal infections. II. Crop rotations and residual effects of non-host plants. New Phytol, 333-343.

Olivera, M., Tejera, N., Iribarne, C., Ocana, A., Lluch, C., 2004. Growth, nitrogen fixation and ammonium assimilation in common bean (Phaseolus vulgaris): effect of phosphorus. Physiol Plantarum 121, 498-505.

Olsen, S.R., 1954. Estimation of available phosphorus in soils by extraction with sodium bicarbonate. Circular. U.S. Dept of Agriculture, 939.

Olson, K.R., Ebelhar, S.A., Lang, J.M., 2010. Cover crop effects on crop yields and soil organic carbon content. Soil Sci 175, 89-98.

Ortiz, N., Armada, E., Duque, E., Roldán, A., Azcón, R., 2015. Contribution of arbuscular mycorrhizal fungi and/or bacteria to enhancing plant drought tolerance under natural soil conditions: Effectiveness of autochthonous or allochthonous strains. J Plant Physiol 174, 87-96.

Paltineanu, I.C., Starr, J.L., 1997. Real-time soil water dynamics using multisensor capacitance probes: laboratory calibration. Soil Sci Soc Am J 61, 1576-1585.

Papadakis, J., 1966. Climates of the World and Their Agricultural Potencialities. DAPCP, Rome, Italy.

Parham, J.A., Deng, S.P., 2000. Detection, quantification and characterization of $\beta$ glucosaminidase activity in soil. Soil Biol Biochem 32, 1183-1190.

Pastor, M., 1988. Sistemas de manejo del suelo del olivar. Tesis dcotoral. Universidad de Córdoba. Córdoba, España.

Peng, S., Guo, T., Liu, G., 2013. The effects of arbuscular mycorrhizal hyphal networks on soil aggregations of purple soil in southwest China. Soil Biol Biochem 57, 411-417. 
Phillips, J.M., Hayman, D.S., 1970. Improved procedures for clearing roots and staining parasitic and vesicular-arbuscular mycorrhizal fungi for rapid assessment of infection. T British Mycol Soc 55, 158-IN118.

Pieters, A., 1927. Green manuring: principles and practice. Ed. John Wiley \& Sons, NY, USA.

Pieters, A., McKee, R., 1938. The use of cover and green-manure crops. Soils and Men, the Yearbook of Agriculture. USDA. US Gov. Print. Off., Washington, DC, USA, 431-444.

Pieters, A.J., 1950. Sericea and other perennial lespedezas for forage and soil conservation. Circular. US Dept of Agriculture. Washington, DC, USA.

Plenchette, C., Fortin, J., Furlan, V., 1983. Growth responses of several plant species to mycorrhizae in a soil of moderate P-fertility. Plant Soil 70, 199-209.

Purin, S., Rillig, M.C., 2007. The arbuscular mycorrhizal fungal protein glomalin: Limitations, progress, and a new hypothesis for its function. Pedobiologia 51, 123-130.

Quemada, M., Cabrera, M., 1995. Carbon and nitrogen mineralized from leaves and stems of four cover crops. Soil Sci Soc Am J 59, 471-477.

Quemada, M., Cabrera, M.L., McCracken, D.V., 1997. Nitrogen release from surfaceapplied cover crop residues: evaluating the CERES-N submodel. Agron J 89, 723-729.

Ramirez-Garcia, J., Martens, H.J., Quemada, M., Thorup-Kristensen, K., 2014. Intercropping effect on root growth and nitrogen uptake at different nitrogen levels. J Plant Ecol, 8(4), 380-389.

Ramírez-García, J., Carrillo, J.M., Ruiz, M., Alonso-Ayuso, M., Quemada, M., 2015. Multicriteria decision analysis applied to cover crop species and cultivars selection. Field Crops Res 175, 106-115.

Reeslev, M., Miller, M., Nielsen, K.F., 2003. Quantifying mold biomass on gypsum board: comparison of ergosterol and beta-N-acetylhexosaminidase as mold biomass parameters. Appl Environ Microbiol 69, 3996-3998.

Reeves, D.W., 1994. Cover crops and rotations. Crops Residue Management. Ed. JL Hatfield and BA Stewart. Adv Soil Sci. Lewis Publishers, Boca Raton, FL., 125172.

Rice, C.W., Moorman, T.B., Beare, M., 1996. Role of microbial biomass carbon and nitrogen in soil quality. Ed. JW Doran and AJ Jones: Methods for assessing soil quality. Soil Sci Soc Am Incororation, Madison, Wisconsin, USA., 203-215.

Rillig, M.C., Wright, S.F., Kimball, B.A., Pinter, P.J., Wall, G.W., Ottman, M.J., Leavitt, S.W., 2001a. Elevated carbon dioxide and irrigation effects on water stable aggregates in a Sorghum field: a possible role for arbuscular mycorrhizal fungi. Glob Change Biol 7, 333-337. 
Rillig, M.C., Wright, S.F., Nichols, K.A., Schmidt, W.F., Torn, M.S., 2001b. Large contribution of arbuscular mycorrhizal fungi to soil carbon pools in tropical forest soils. Plant Soil 233, 167-177.

Rillig, M.C., Wright, S.F., Eviner, V.T., 2002. The role of arbuscular mycorrhizal fungi and glomalin in soil aggregation: comparing effects of five plant species. Plant Soil 238, 325-333.

Rillig, M.C., Ramsey, P.W., Morris, S., Paul, E.A., 2003. Glomalin, an arbuscularmycorrhizal fungal soil protein, responds to land-use change. Plant Soil 253, 293-299.

Rillig, M.C., 2004. Arbuscular mycorrhizae, glomalin, and soil aggregation. Can J Soil Sci 84, 355-363.

Rillig, M.C., Mummey, D.L., 2006. Mycorrhizas and soil structure. New Phytol 171, 41-53.

Ritchie, S.W., Hanway, J.J., Benson, G.O., 1992. How a corn plant develops. Special Report Nro. 48. Iowa State University of Science and Technology. Ames, IW, USA, 21 pp.

Roscoe, R., Vasconcellos, C.A., Furtini-Neto, A.E., Guedes, G.A., Fernandes, L.A., 2000. Urease activity and its relation to soil organic matter, microbial biomass nitrogen and urea-nitrogen assimilation by maize in a Brazilian Oxisol under no-tillage and tillage systems. Biol Fert Soils 32, 52-59.

Ruiz-Lozano, J.M., Azcon, R., 1996. Viability and infectivity of mycorrhizal spores after long term storage in soils with different water potentials. Appl Soil Ecol 3, 183-186.

Sainju, U.M., Jabro, J.D., Stevens, W.B., 2008. Soil carbon dioxide emission and carbon content as affected by irrigation, tillage, cropping system, and nitrogen fertilization. J Environ Qual 37, 98-106.

Salmerón, M., Cavero, J., Quílez, D., Isla, R., 2010. Winter cover crops affect monoculture maize yield and nitrogen leaching under irrigated Mediterranean conditions. Agron J 102, 1700-1709.

Sastre, B., Barbero-Sierra, C., Bienes, R., Marques, M.J., García-Díaz, A., 2016. Soil loss in an olive grove in Central Spain under cover crops and tillage treatments, and farmer perceptions. J Soils Sediment, 1-16.

Semple, E.C., 1928. Ancient Mediterranean agriculture: Part II. Manuring and seed selection. Agr Hist 2, 129-156.

Sieverding, E., 1991. Vesicular-Arbuscular Mycorrhiza Managament in Tropical Agrosystems. Deutsche Gesellschaft für Technische Zusammenarbeit (GTZ) $\mathrm{GmbH}$, Friedland, Germany.

Six, J., Elliott, E.T., Paustian, K., 2000. Soil macroaggregate turnover and microaggregate formation: a mechanism for $\mathrm{C}$ sequestration under no-tillage agriculture. Soil Biol Biochem 32, 2099-2103. 
Six, J., Bossuyt, H., Degryze, S., Denef, K., 2004. A history of research on the link between (micro) aggregates, soil biota, and soil organic matter dynamics. Soil Till Res 79, 7-31.

Smith, F.A., Grace, E.J., Smith, S.E., 2009. More than a carbon economy: nutrient trade and ecological sustainability in facultative arbuscular mycorrhizal symbioses. New Phytol 182, 347-358.

Smith, S.E., Read, D.J., 2008. Mycorrhizal symbiosis, 3rd edn. Academic press, London, UK.

Snapp, S., Swinton, S., Labarta, R., Mutch, D., Black, J., Leep, R., Nyiraneza, J., O'Neil, K., 2005. Evaluating cover crops for benefits, costs and performance within cropping system niches. Agron J 97, 322-332.

Soil Survey Staff, 2014. Keys to Soil Taxonomy, 12th ed. USDA-Natural Resources Conservation Service, Washington, DC.

Sorensen, J.N., Larsen, J., Jakobsen, I., 2005. Mycorrhiza formation and nutrient concentration in leeks (Allium porrum) in relation to previous crop and cover crop management on high P soils. Plant Soil 273, 101-114.

Sparling, G.P., 1992. Ratio of microbial biomass carbon to soil organic carbon as a sensitive indicator of changes in soil organic matter. Soil Res 30, 195-207.

Spohn, M., Kuzyakov, Y., 2013. Distribution of microbial-and root-derived phosphatase activities in the rhizosphere depending on $\mathrm{P}$ availability and $\mathrm{C}$ allocation-Coupling soil zymography with $14 \mathrm{C}$ imaging. Soil Biol Biochem 67, 106-113.

Steenwerth, K.L., Pierce, D.L., Carlisle, E.A., Spencer, R.G., Smart, D.R., 2010. A vineyard agroecosystem: disturbance and precipitation affect soil respiration under Mediterranean conditions. Soil Sci Soc Am J 74, 231-239.

Steinberg, P.D., Rillig, M.C., 2003. Differential decomposition of arbuscular mycorrhizal fungal hyphae and glomalin. Soil Biol Biochem 35, 191-194.

Stetson, S.J., Osborne, S.L., Eynard, A., Chilom, G., Rice, J., Nichols, K.A., Pikul, J.L., 2012. Corn residue removal impact on topsoil organic carbon in a cornsoybean rotation. Soil Sci Soc Am J 76, 1399-1406.

Strobl, W., Traunmüller, M., Schinner, F., Öhlinger, R., Kandeler, E., Margesin, R., 1996. $\beta$-Glucosidase activity. Methods in Soil Biology. F. Schinner, R. Öhlinger, E. Kandeler, and R. Margesin (eds.). Springer, Berlin, Germany, 198-200.

Tabatabai, M., Bremner, J., 1969. Use of p-nitrophenyl phosphate for assay of soil phosphatase activity. Soil Biol Biochem 1, 301-307.

Tabatabai, M., Bremner, J., 1970. Arylsulfatase activity of soils. Soil Sci Soc Am J 34, 225-229.

Tabatabai, M., 1994. Soil enzymes. P.S. Bottomley, J.S. Angle, R.W. Weaver, editors, Methods of Soil Analysis: Part 2-Microbiological and Biochemical Properties, SSSA, Madison, WI, 775-833. 
Tanaka, Y., Yano, K., 2005. Nitrogen delivery to maize via mycorrhizal hyphae depends on the form of N supplied. Plant Cell Environ 28, 1247-1254.

Tejada, M., Gonzalez, J., García-Martínez, A., Parrado, J., 2008. Effects of different green manures on soil biological properties and maize yield. Bioresource Technol 99, 1758-1767.

Thorup-Kristensen, K., Magid, J., Jensen, L.S., 2003. Catch crops and green manures as biological tools in nitrogen management in temperate zones. Adv Agron 79, 227-302.

Tonitto, C., David, M., Drinkwater, L., 2006. Replacing bare fallows with cover crops in fertilizer-intensive cropping systems: A meta-analysis of crop yield and $\mathrm{N}$ dynamics. Agr Ecosyst Environ 112, 58-72.

Tosti, G., Benincasa, P., Farneselli, M., Pace, R., Tei, F., Guiducci, M., ThorupKristensen, K., 2012. Green manuring effect of pure and mixed barley-hairy vetch winter cover crops on maize and processing tomato $\mathrm{N}$ nutrition. Eur J Agron 43, 136-146.

Tosti, G., Benincasa, P., Farneselli, M., Tei, F., Guiducci, M., 2014. Barley-hairy vetch mixture as cover crop for green manuring and the mitigation of $\mathrm{N}$ leaching risk. Eur J Agron 54, 34-39.

Turrini, A., Sbrana, C., Avio, L., Njeru, E.M., Bocci, G., Bàrberi, P., Giovannetti, M., 2016. Changes in the composition of native root arbuscular mycorrhizal fungal communities during a short-term cover crop-maize succession. Biol Fert Soils, 1-11.

Unger, P.W., Vigil, M.F., 1998. Cover crop effects on soil water relationships. J Soil Water Conserv 53, 200-207.

Van Der Heijden, M.G., Streitwolf-Engel, R., Riedl, R., Siegrist, S., Neudecker, A., Ineichen, K., Boller, T., Wiemken, A., Sanders, I.R., 2006. The mycorrhizal contribution to plant productivity, plant nutrition and soil structure in experimental grassland. New Phytol 172, 739-752.

Veenstra, J.J., Horwath, W.R., Mitchell, J., 2007. Tillage and cover cropping effects on aggregate-protected carbon in cotton and tomato. Soil Sci Soc Am J 71, 362371.

Veresoglou, S.D., Chen, B., Rillig, M.C., 2012. Arbuscular mycorrhiza and soil nitrogen cycling. Soil Biol Biochem 46, 53-62.

Vierheilig, H., Coughlan, A.P., Wyss, U., Piche, Y., 1998. Ink and vinegar, a simple staining technique for arbuscular-mycorrhizal fungi. Appl Environ Microb 64, 5004-5007.

Villamil, M.B., Bollero, G.A., Darmody, R.G., Simmons, F.W., Bullock, D.G., 2006. Notill corn/soybean systems including winter cover crops. Soil Sci Soc Am J 70, 1936-1944. 
Walley, F.L., Germida, J.J., 1995. Estimating the viability of vesicular-arbuscular mycorrhizae fungal spores using tetrazolium salts as vital stains. Mycologia, 273-279.

Wang, B., Qiu, Y.-L., 2006. Phylogenetic distribution and evolution of mycorrhizas in land plants. Mycorrhiza 16, 299-363.

Watanabe, F., Olsen, S., 1965. Test of an ascorbic acid method for determining phosphorus in water and $\mathrm{NaHCO}_{3}$ extracts from soil. Soil Sci Soc Am J 29, 677-678.

White, C.M., Weil, R.R., 2010. Forage radish and cereal rye cover crop effects on mycorrhizal fungus colonization of maize roots. Plant Soil 328, 507-521.

White, R., Ayoub, A., 1983. Decomposition of plant residues of variable C/P ratio and the effect on soil phosphate availability. Plant Soil 74, 163-173.

Wood, C.W., Torbert, H.A., Rogers, H.H., Runion, G.B., Prior, S.A., 1994. Free-air CO2 enrichment effects on soil carbon and nitrogen. Agr Forest Meteorol 70, 103116.

Wortman, S.E., Francis, C., Lindquist, J.L., 2012. Cover crop mixtures for the western Corn Belt: Opportunities for increased productivity and stability. Agron J 104, 699-705.

Wortman, S.E., Francis, C.A., Bernards, M.A., Blankenship, E.E., Lindquist, J.L., 2013. Mechanical termination of diverse cover crop mixtures for improved weed suppression in organic cropping systems. Weed Science 61, 162-170.

Wright, D.P., Read, D.J., Scholes, J.D., 1998. Mycorrhizal sink strength influences whole plant carbon balance of Trifolium repens L. Plant Cell Environ 21, 881891.

Wright, S.F., Upadhyaya, A., 1998. A survey of soils for aggregate stability and glomalin, a glycoprotein produced by hyphae of arbuscular mycorrhizal fungi. Plant Soil 198, 97-107.

Wright, S.F., Starr, J.L., Paltineanu, I.C., 1999. Changes in aggregate stability and concentration of glomalin during tillage management transition. Soil Sci Soc Am J 63, 1825-1829.

Wright, S.F., Upadhyaya, A., 1999. Quantification of arbuscular mycorrhizal fungi activity by the glomalin concentration on hyphal traps. Mycorrhiza 8, 283285.

Wright, S.F., Anderson, R.L., 2000. Aggregate stability and glomalin in alternative crop rotations for the central Great Plains. Biol Fert Soils 31, 249-253.

Wu, Q.-S., Cao, M.-Q., Zou, Y.-N., He, X.-h., 2014. Direct and indirect effects of glomalin, mycorrhizal hyphae, and roots on aggregate stability in rhizosphere of trifoliate orange. Scientific Reports 4, 5823.

Yang, H., Zhang, Q., Dai, Y., Liu, Q., Tang, J., Bian, X., Chen, X., 2015. Effects of arbuscular mycorrhizal fungi on plant growth depend on root system: a meta-analysis. Plant Soil 389, 361-374. 
Zhao, S., Li, K., Zhou, W., Qiu, S., Huang, S., He, P., 2016. Changes in soil microbial community, enzyme activities and organic matter fractions under long-term straw return in north-central China. Agr, Ecosyst Environ 216, 82-88.

Zhu, B., Yi, L., Guo, L., Chen, G., Hu, Y., Tang, H., Xiao, C., Xiao, X., Yang, G., Acharya, S.N., 2012. Performance of two winter cover crops and their impacts on soil properties and two subsequent rice crops in Dongting Lake Plain, Hunan, China. Soil Till Res 124, 95-101.

Zhu, Y.-G., Laidlaw, A., Christie, P., Hammond, M., 2000. The specificity of arbuscular mycorrhizal fungi in perennial ryegrass-white clover pasture. Agr Ecosyst Environ 77, 211-218. 